\title{
National Weatherization Assistance Program Impact Evaluation Weatherization Staff Survey
}

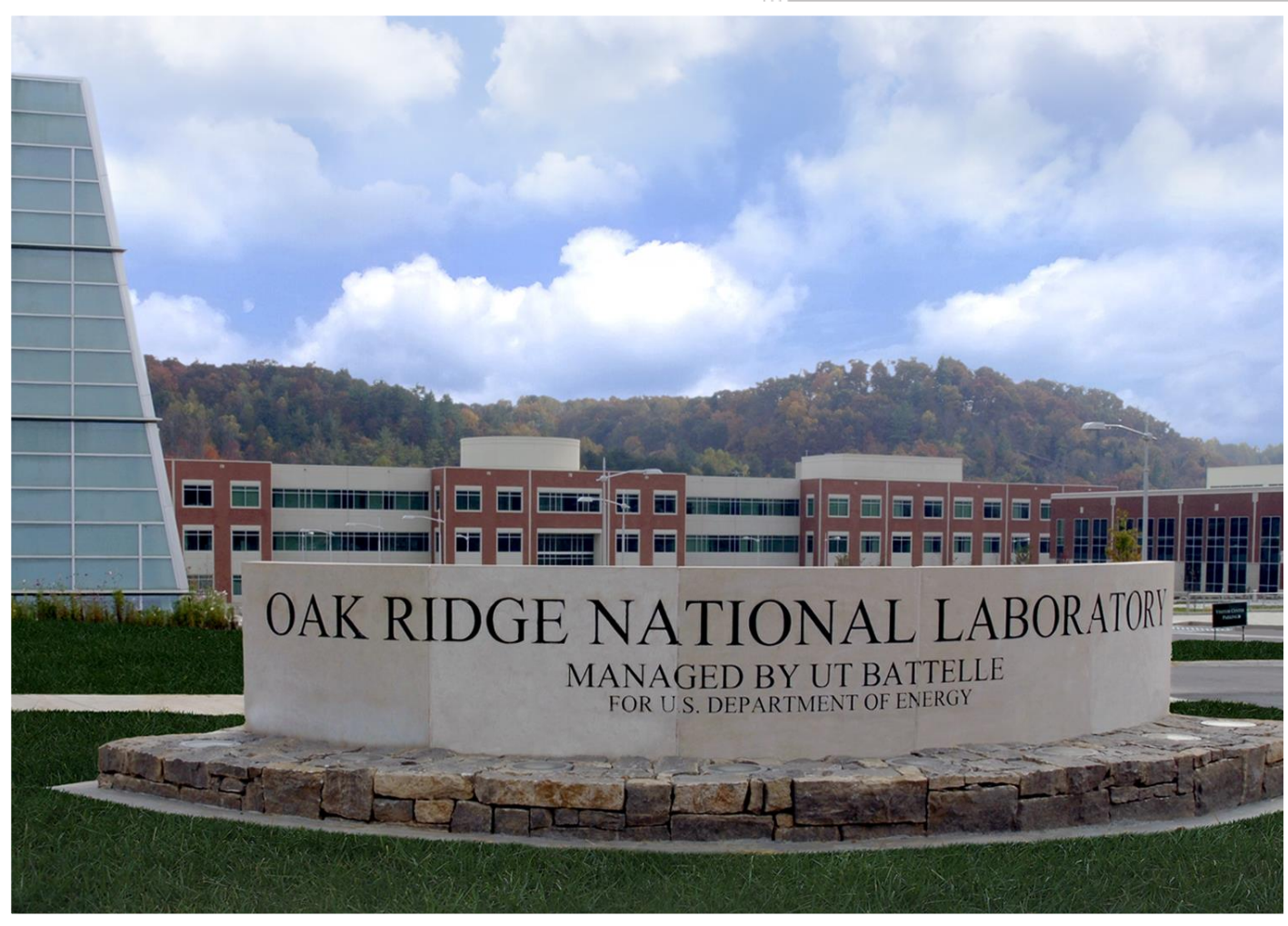

David Carroll Jacqueline Berger Caroline Miller Daya Bill Johnson

February 2015 


\section{DOCUMENT AVAILABILITY}

Reports produced after January 1, 1996, are generally available free via US Department of Energy (DOE) SciTech Connect.

Website http://www.osti.gov/scitech/

Reports produced before January 1, 1996, may be purchased by members of the public from the following source:

National Technical Information Service

5285 Port Royal Road

Springfield, VA 22161

Telephone 703-605-6000 (1-800-553-6847)

TDD 703-487-4639

Fax 703-605-6900

E-mail info@ntis.gov

Website http://www.ntis.gov/help/ordermethods.aspx

Reports are available to DOE employees, DOE contractors, Energy Technology Data Exchange representatives, and International Nuclear Information System representatives from the following source:

Office of Scientific and Technical Information

PO Box 62

Oak Ridge, TN 37831

Telephone 865-576-8401

Fax 865-576-5728

E-mail reports@osti.gov

Website http://www.osti.gov/contact.html

This report was prepared as an account of work sponsored by an agency of the United States Government. Neither the United States Government nor any agency thereof, nor any of their employees, makes any warranty, express or implied, or assumes any legal liability or responsibility for the accuracy, completeness, or usefulness of any information, apparatus, product, or process disclosed, or represents that its use would not infringe privately owned rights. Reference herein to any specific commercial product, process, or service by trade name, trademark, manufacturer, or otherwise, does not necessarily constitute or imply its endorsement, recommendation, or favoring by the United States Government or any agency thereof. The views and opinions of authors expressed herein do not necessarily state or reflect those of the United States Government or any agency thereof.

ORNL Principal Investigator

Dr. Bruce Tonn

Evaluation Team Task Manager

Jacqueline Berger, Ph.D. 
Environmental Sciences Division

\title{
NATIONAL WEATHERIZATION ASSISTANCE PROGRAM IMPACT EVALUATION WEATHERIZATION STAFF SURVEY
}

\author{
David Carroll, APPRISE \\ Jacqueline Berger, APPRISE \\ Carolyn Miller, Carolyn Miller Consulting \\ Daya Bill Johnson, APPRISE
}

February 2015

\author{
Prepared by \\ OAK RIDGE NATIONAL LABORATORY \\ Oak Ridge, Tennessee 37831-6283 \\ managed by \\ UT-BATTELLE, LLC \\ for the \\ US DEPARTMENT OF ENERGY \\ under contract DE-AC05-00OR22725
}





\section{CONTENTS}

Page

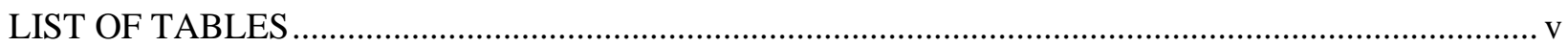

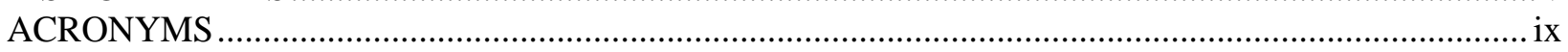

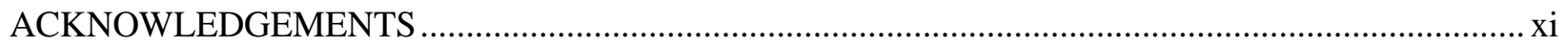

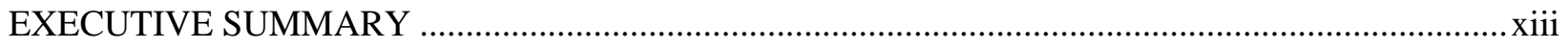

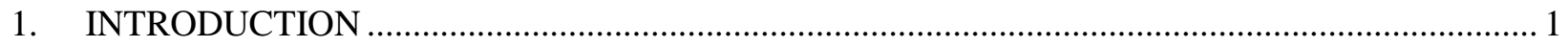

1.1 NATIONAL WEATHERIZATION ASSISTANCE PROGRAM EVALUATION

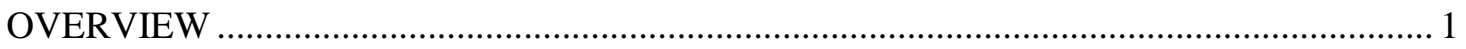

1.2 WEATHERIZATION STAFF SURVEY STUDY OVERVIEW …..................................... 2

1.3 ORGANIZATION OF THE BASELINE OCCUPANT SURVEY REPORT ....................... 3

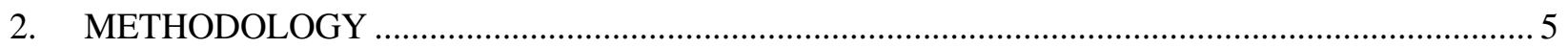

2.1 SAMPLE FRAME DEVELOPMENT AND SAMPLE SELECTION PROCEDURES............5

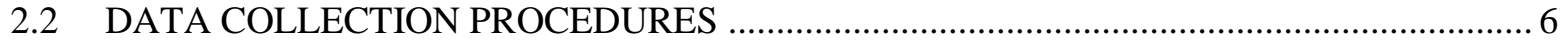

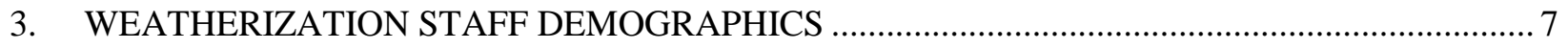

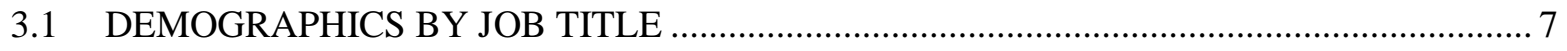

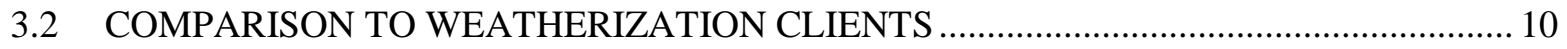

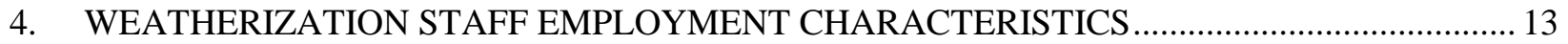

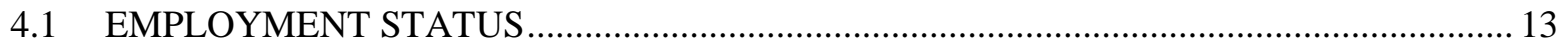

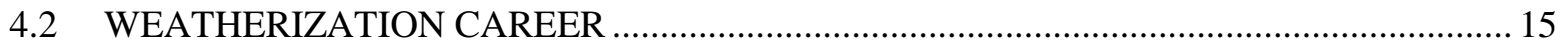

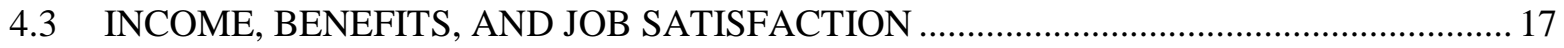

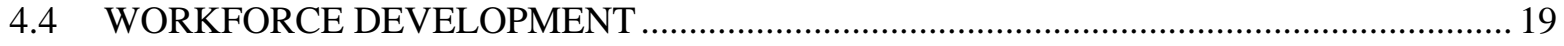

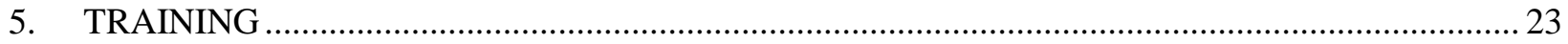

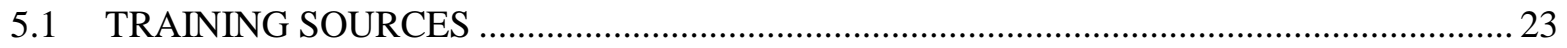

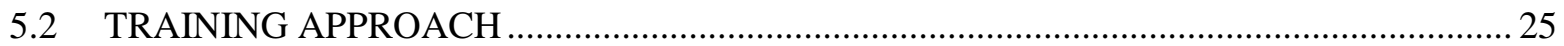

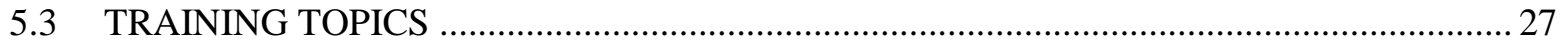

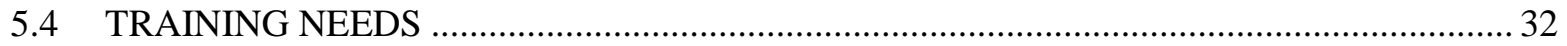

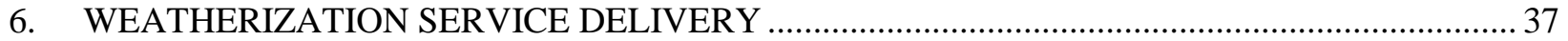

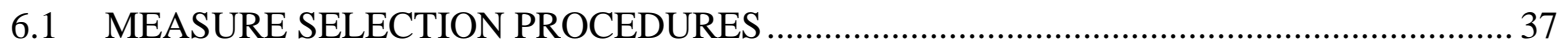

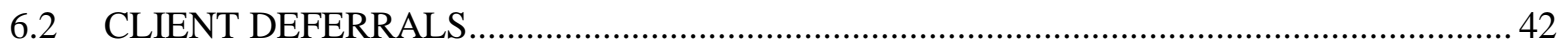

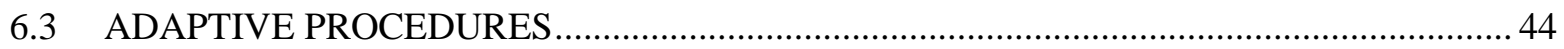

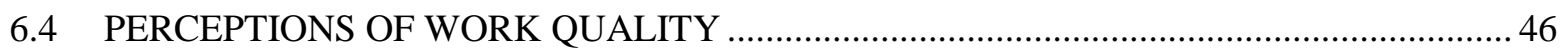

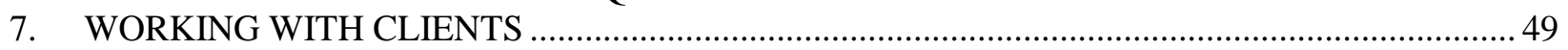

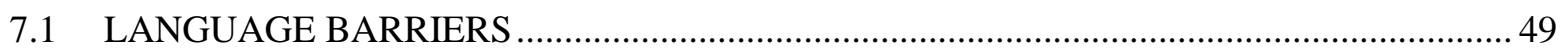

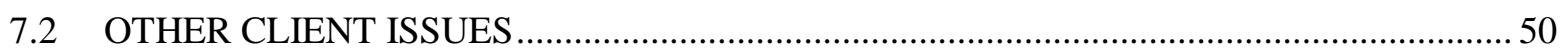

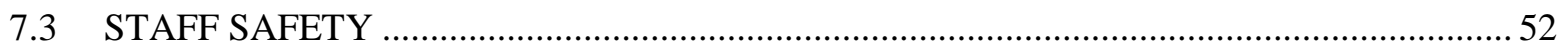

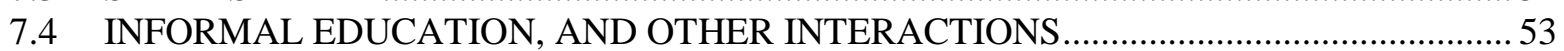

8. AGENCY VS. CONTRACTOR CREW CHIEF FINDINGS ….................................................. 57

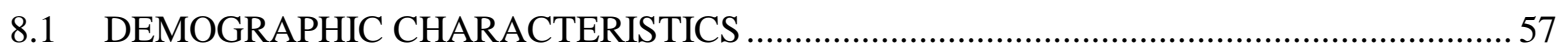

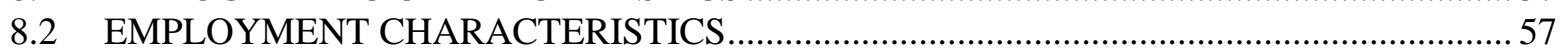

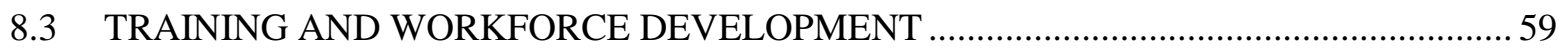

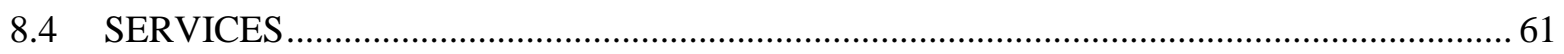

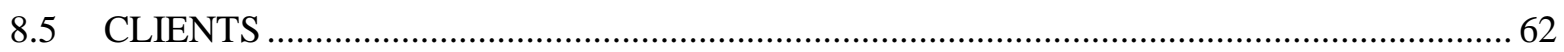

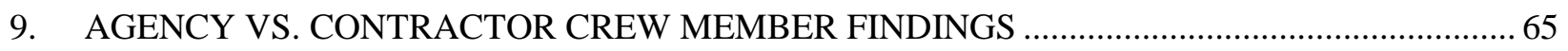

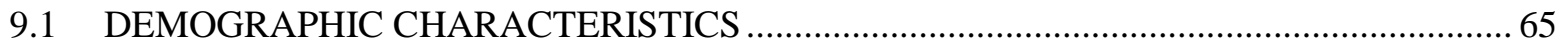

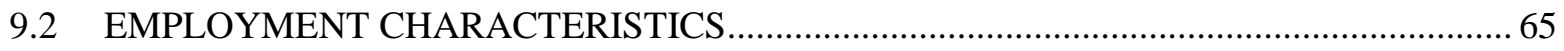

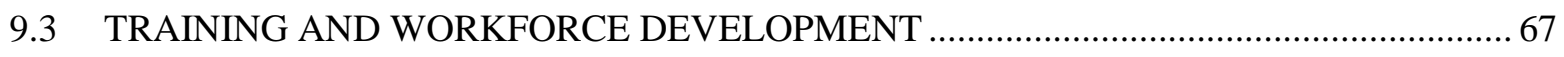

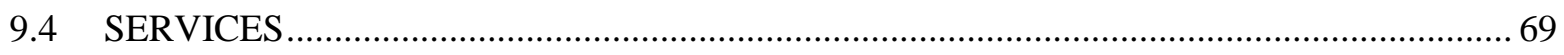


9.5 CLIENTS ......

APPENDIX A. WEATHERIZATION STAFF FOLLOW-UP SURVEY RESULTS .

A-3 


\section{LIST OF TABLES}

Table

Page

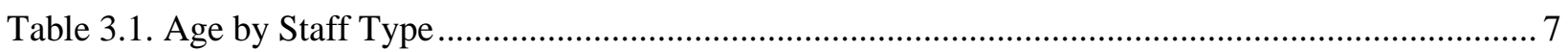

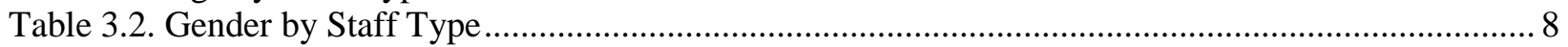

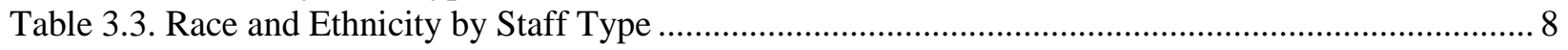

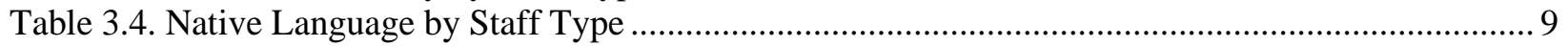

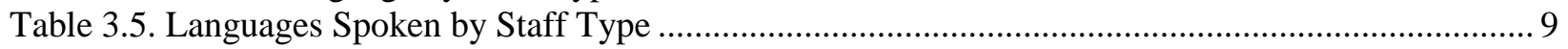

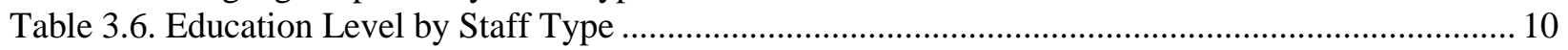

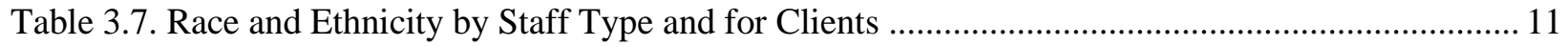

Table 3.8. Age, Race/Ethnicity, and Gender by Staff Type .................................................................. 11

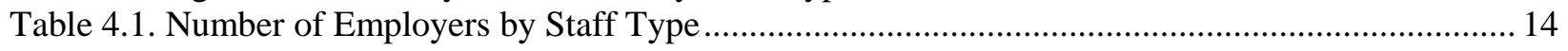

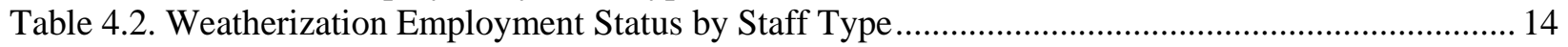

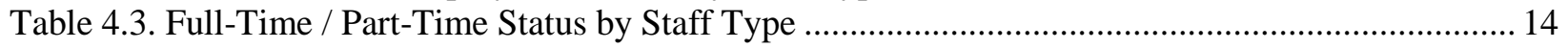

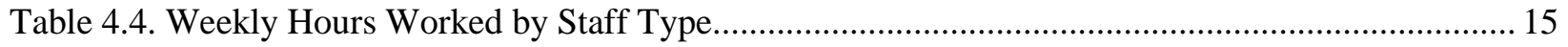

Table 4.5. PY 2011 Weatherization Staff Survey Low-Income Weatherization as a Long-Term

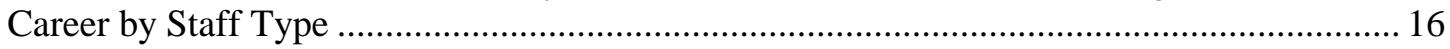

Table 4.6. Years Working in Low-Income Weatherization by Staff Type ............................................. 16

Table 4.7. Years Employed by Current Weatherization Employer by Staff Type................................... 16

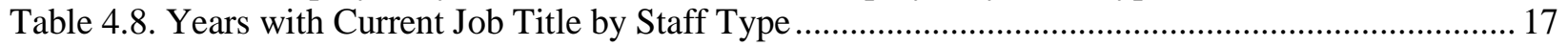

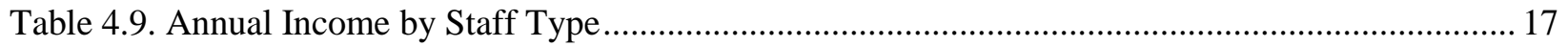

Table 4.10. Health Insurance Coverage by Staff Type ........................................................................... 18

Table 4.11. Job Satisfaction (Ratings of Satisfactory or Very Satisfactory) by Staff Type....................... 19

Table 4.12. Likelihood of Unemployment by Staff Type ....................................................................... 20

Table 4.13. Value of Training for Finding a New Job by Staff Type ....................................................... 20

Table 4.14. Value of Experience for Finding a New Job by Staff Type ................................................... 20

Table 4.15. Usefulness of Training in Other Fields and/or Jobs by Staff Type ....................................... 21

Table 4.16. Usefulness of Experience in Other Fields and/or Jobs by Staff Type.................................. 21

Table 5.1. Skills Learned Prior to Entering Weatherization Field .......................................................... 24

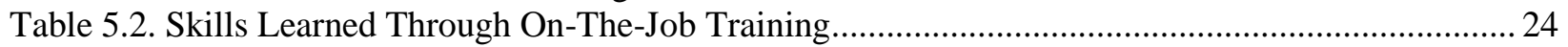

Table 5.3. Skills Learned Through Weatherization Training ............................................................ 25

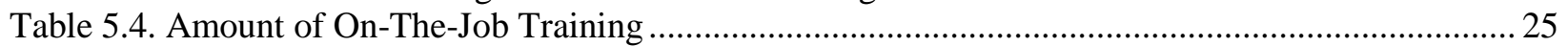

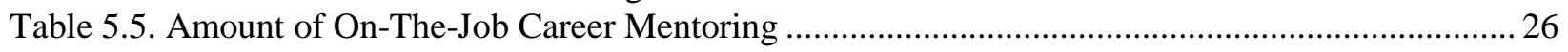

Table 5.6. One or More Types of Formal Weatherization Training .................................................... 26

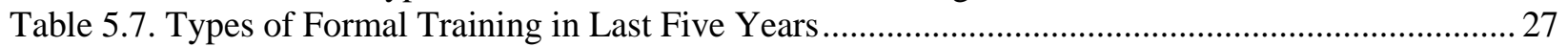

Table 5.8a. Formal Training Topics in Last Five Years - Any Building Type ....................................... 28

Table 5.8b. Training on Infiltration/Air Sealing in Last Five Years - Any Building Type.......................28

Table 5.9a. Formal Training Topics in Last Five Years - Single Family Homes .................................... 29

Table 5.9b. Formal Training Topics in Last Five Years - Mobile Homes .............................................. 29

Table 5.9c. Formal Training Topics in Last Five Years - Multifamily ..................................................29

Table 5.10. Training on Health and Safety Topics in Last Five Years …................................................ 30

Table 5.11. Professional Development Training in Last Five Years ..................................................... 31

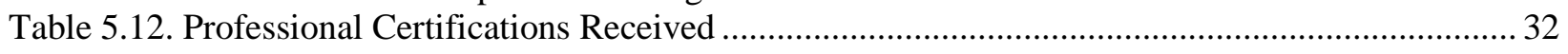

Table 5.13. Any Training Needed but Not Received..................................................................... 33

Table 5.14a. Topics on Which Training Is Needed - Single Family Homes ........................................... 33

Table 5.14b. Topics on Which Training Is Needed - Mobile Homes ......................................................... 33

Table 5.14c. Topics on Which Training Is Needed - Multifamily Homes .............................................. 34

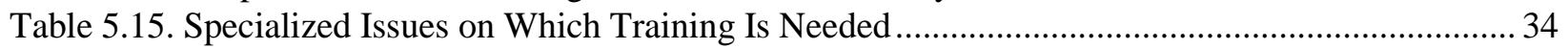

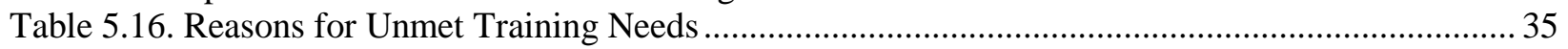


Table 5.17. Ability of Crew to Meet Weatherization Requirements ................................................... 35

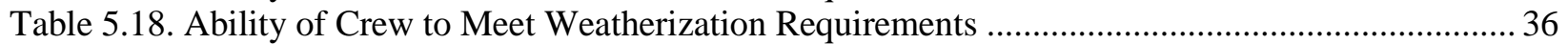

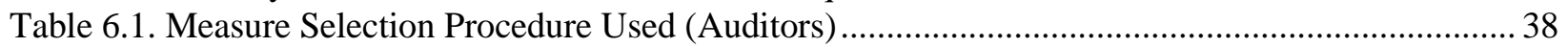

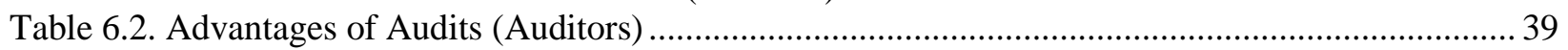

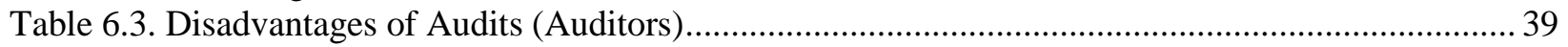

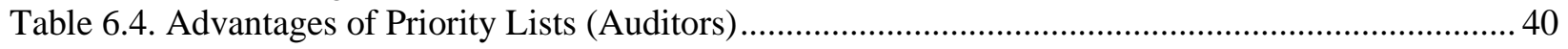

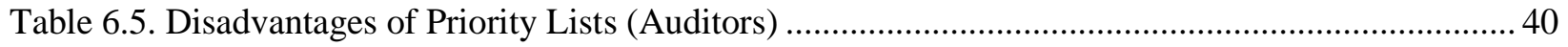

Table 6.6. Reluctant to Include Measures on Job Orders (Auditors) ....................................................... 40

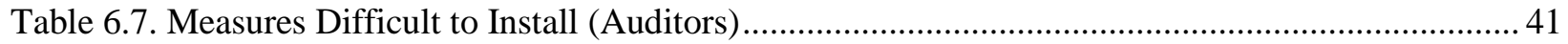

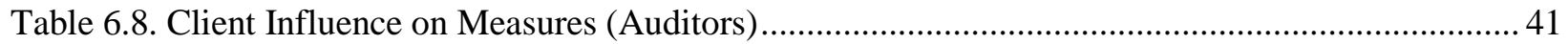

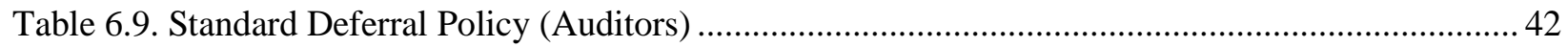

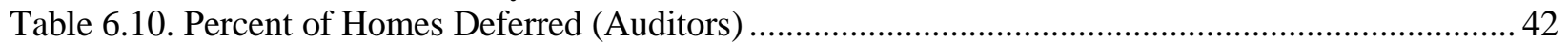

Table 6.11. Reasons for Deferral - Frequently or Very Frequently (Auditors) ......................................... 43

Table 6.12. Communication with Client about Deferral (Auditors) ….................................................. 44

Table 6.13. Referral of Households to Other Providers (Auditors) .......................................................... 44

Table 6.14. Share of Homes Where Unspecified Measures Installed (Crew Chiefs) ................................ 45

Table 6.15. PY 2011 Weatherization Staff SurveyShare of Homes Where Specified Measures Not

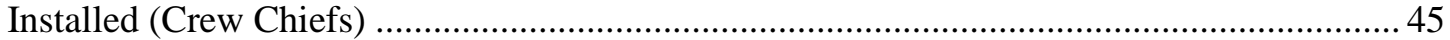

Table 6.16. Share of Homes Requiring Solutions Beyond Standard Practices (Crew Chiefs) ................... 46

Table 6.17. Clarification or Interpretation from Auditors (Crew Chiefs) .............................................. 46

Table 6.18. Crew Work Quality - Percent with Ratings of "Excellent" or "Very Good" .......................... 47

Table 6.19. Hindrances to Crew Chief Responsibilities - Ratings of "Extremely Great" or "Very

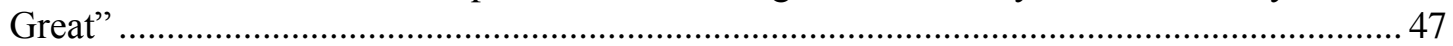

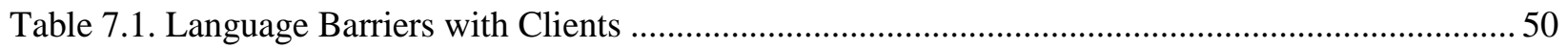

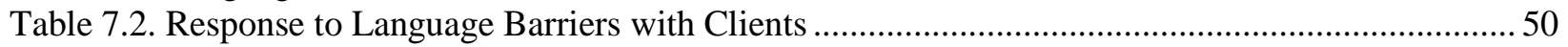

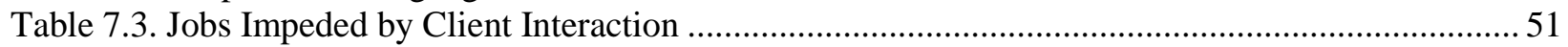

Table 7.4. Response When Jobs Impeded by Client Interaction........................................................... 51

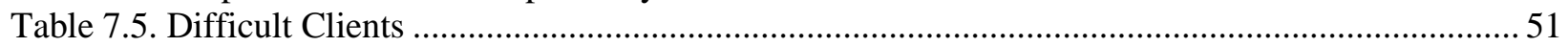

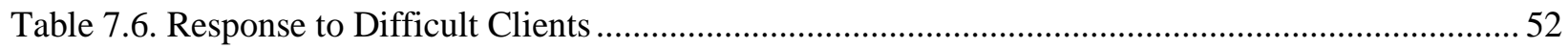

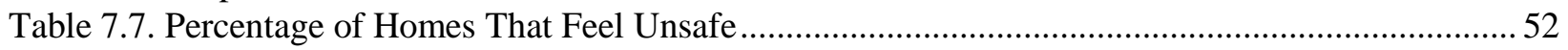

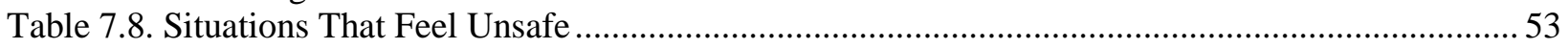

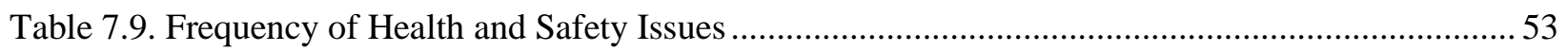

Table 7.10. Informal Energy Education Provided to Client...................................................................... 54

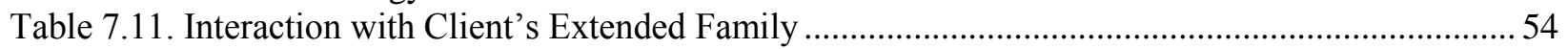

Table 7.12. Interaction with Client's Neighbors.................................................................................... 54

Table 7.13. Informal Energy Education Provided to Client's Extended Family or Neighbors .................. 55

Table 8.1. Crew Chief Demographics - Agency Staff Compared to Contractors ..................................... 57

Table 8.2. Crew Chief Employment Status - Agency Staff Compared to Contractors ..............................58

Table 8.3. Crew Chief Weatherization Career - Agency Staff Compared to Contractors......................... 58

Table 8.4. Crew Chief Income and Benefits - Agency Staff Compared to Contractors............................ 59

Table 8.5. Crew Chief Workforce Development - Agency Staff Compared to Contractors...................... 59

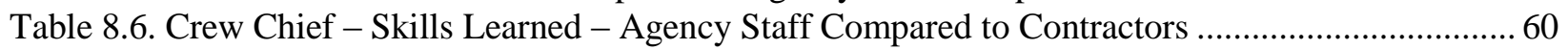

Table 8.7. Crew Chief - Training Approach - Agency Staff Compared to Contractors ........................... 60

Table 8.8. Crew Chief - Formal Training Topics - Agency Staff Compared to Contractors ..................... 61

Table 8.9. Crew Chief - Training Needs - Agency Staff Compared to Contractors ................................. 61

Table 8.10. Crew Chief - Reasons for Unmet Training Needs - Agency Staff Compared to

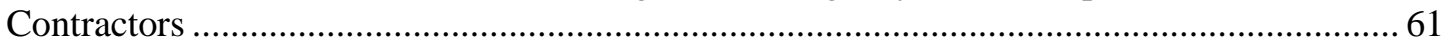

Table 8.11. Crew Chief - Installation Practices - Agency Staff Compared to Contractors ...................... 62

Table 8.12. Crew Chief - Installation Quality - Agency Staff Compared to Contractors.......................... 62

Table 8.13. Crew Chief - Client Interactions - Agency Staff Compared to Contractors.......................... 62

Table 8.14. Crew Chief - Staff Feel Unsafe - Agency Staff Compared to Contractors........................... 63 
Table 9.1. Crew Chief Demographics - Agency Staff Compared to Contractors . 65

Table 9.2. Crew Member Employment Status - Agency Staff Compared to Contractors.......................... 66

Table 9.3. Crew Member Weatherization Career - Agency Staff Compared to Contractors ...................... 66

Table 9.4. Crew Member Income and Benefits - Agency Staff Compared to Contractors ....................... 66

Table 9.5. Crew Member - Workforce Development - Agency Staff Compared to Contractors ................ 67

Table 9.6. Crew Member - Skills Learned - Agency Staff Compared to Contractors ............................... 67

Table 9.7. Crew Member - Training Approach - Agency Staff Compared to Contractors ....................... 68

Table 9.8. Crew Member - Formal Training Topics - Agency Staff Compared to Contractors ................. 68

Table 9.9. Crew Member - Training Needs - Agency Staff Compared to Contractors ............................. 69

Table 9.10. Crew Member - Reasons for Unmet Training Needs - Agency Staff Compared to Contractors

Table 9.11. Crew Chief - Installation Quality - Agency Staff Compared to Contractors........................ 69

Table 9.12. Crew Member - Client Interactions - Agency Staff Compared to Contractors ...................... 70

Table 9.13. Crew Member - Staff Feel Unsafe - Agency Staff Compared to Contractors ....................... 70

Table A.1 Employment Status of Weatherization Staff Respondents in 2013 ........................................ 



\section{ACRONYMS}

$\begin{array}{ll}\text { ARRA } & \text { American Recovery and Reinvestment Act of } 2009 \\ \text { BLS } & \text { Bureau of Labor Statistics } \\ \text { CFR } & \text { Code of Federal Regulations } \\ \text { CPS } & \text { Current Population Survey } \\ \text { DOE } & \text { Department of Energy } \\ \text { ECM } & \text { Energy Conservation Measure } \\ \text { ECW } & \text { Energy Center of Wisconsin } \\ \text { ORNL } & \text { Oak Ridge National Laboratory } \\ \text { PY } & \text { Program Year } \\ \text { WAP } & \text { Weatherization Assistance Program }\end{array}$





\section{ACKNOWLEDGEMENTS}

The work presented in this report was funded by the U.S. Department of Energy's (DOE) Office of Weatherization and Intergovernmental Programs (OWIP).

This report summarizes the findings from the Baseline Weatherization Staff Survey of the Weatherization Assistance Program (WAP) Evaluation. In this study, the evaluation team obtained lists of weatherization staff from 200 local weatherization agencies in all 50 states and the District of Columbia and conducted surveys with 350 auditors, 268 crew chiefs, and 264 crew members.

The original design for the survey was developed by staff from the Oak Ridge National Laboratory (ORNL) as one component of the National Evaluation of the Weatherization Assistance Program. (National Evaluation of the Weatherization Assistance Program: Preliminary Evaluation Plan for Program Year 2006 - ORNL/CON-498). As part of the evaluation plan development the design team consulted with and received feedback from the Network Planning Committee, 41 individuals from the weatherization network.

ORNL contracted with the research team of APPRISE Incorporated, the Energy Center of Wisconsin, Michael Blasnik and Associates, and Dalhoff Associates LLC to conduct the National Evaluation. APPRISE took primary responsibility for the design and implementation of this study. The members of the Evaluation Team who contributed to the design and implementation of this survey included:

\section{APPRISE Incorporated}

Jackie Berger

David Carroll

Colleen Driscoll

Jennifer Frenett

Daya Bill Johnson

Ferit Ucar

Anne Worth

\section{The Energy Center of Wisconsin}

Claire Cowan

LaShanta Goodwin

Jaimie Rule

\author{
Carolyn Miller Consulting \\ Carolyn Miller
}

Dieringer Research Group (DRG) prepared the on-line survey instrument that was used by some respondents to respond to the survey and was used by the project team to record responses for staff who completed paper questionnaires.

This study could only be completed with the cooperation and contributions of the 51 grantees and 200 subgrantees who furnished lists of weatherization staff. In addition, the study depended on the willingness of the 882 weatherization staff to share their perceptions and experiences with the evaluation team.

Finally, we would like to acknowledge the assistance and guidance of the Oak Ridge National Laboratory, Department of Energy Project Officers, and Department of Energy Headquarters Staff.

Jackie Berger

David Carroll 



\section{EXECUTIVE SUMMARY}

The purpose of this report is to disseminate the findings from the Baseline Weatherization Staff Survey. This survey was conducted with agency staff and contractors who provided services under the Weatherization Assistance Program (WAP) in Program Year (PY) 2011. The interviews were conducted with three types of weatherization staff: auditors/inspectors, crew chiefs/foremen, and crew members/technicians. This report presents the findings for the three staff groups side by side so that their characteristics, experiences, and perceptions can be compared.

\section{Background}

The U.S. Department of Energy's (DOE) WAP was created by Congress in 1976 under Title IV of the Energy Conservation and Production Act. The purpose and scope of the Program as currently stated in the Code of Federal Regulations (CFR) 10 CFR 440.1 is "to increase the energy efficiency of dwellings owned or occupied by low-income persons, reduce their total residential energy expenditures, and improve their health and safety, especially low-income persons who are particularly vulnerable such as the elderly, persons with disabilities, families with children, high residential energy users, and households with high energy burden." (Code of Federal Regulations, 2011)

At the request of DOE, Oak Ridge National Laboratory (ORNL) developed a comprehensive plan for a national evaluation of WAP that was published in 2007. DOE furnished funding to ORNL in 2009 for a national evaluation for PYs 2007 and 2008, with a particular emphasis on PY 2008. The Scope of Work (SOW) for the evaluation includes an Impact Assessment, a Process Assessment, Special Technical Studies, and a Synthesis Report ${ }^{1}$. The Staff Surveys contribute to both the Impact and Process Assessments.

\section{Weatherization Staff Survey Overview}

The Weatherization Staff Survey was conducted with a representative sample of weatherization staff from 200 local agencies that delivered services in PY 2011. Sampled staff were asked to complete a selfadministered questionnaire that collected information on a broad range of topics, including: demographic information, employment status, training, assessment of service delivery quality, and perceptions of WAP clients. Surveys were completed by 350 auditors, 268 crew chiefs, and 264 crew members.

One purpose of the Weatherization Staff Survey is to furnish DOE and other policymakers with information that helps to characterize the weatherization workforce. However, another important purpose of the Weatherization Staff Survey is to measure and quantify the employment and workforce development nonenergy benefits associated with the WAP program. The findings from the surveys will be used in both the Process and Impact Reports on the Program.

\section{Weatherization Staff Demographics}

The Weatherization Staff Survey showed that the individuals who deliver weatherization services to lowincome households are diverse in terms of age, race and ethnicity, and education; they are likely to bring many different skills and experiences to the WAP program. The survey found that at least some staff are

\footnotetext{
${ }^{1}$ Tonn et al. 2014. Weatherization Works - Summary of Findings from the Retrospective Evaluation of the U.S. Department of Energy's Weatherization Assistance Program. ORNL/TM-2014/338, Oak Ridge National Laboratory, Oak Ridge, Tennessee. National Laboratory, Oak Ridge, TN.
} 
comfortable conversing with clients in Spanish or other languages. The survey also found that very few women are employed as service delivery staff for the WAP program.

Some key statistics from the survey include:

- Age - Most weatherization staff are between 21 and 60 years old. Auditors and crew chiefs tend to be a little older than crew members. However, some auditors are in their 20's and some crew members are in their 50's.

- Gender - Relatively few weatherization staff are women-7 percent of auditors, 2 percent of crew chiefs, and 3 percent of crew.

- Race/Ethnicity - About 80 percent of auditors, 80 percent of crew chiefs, and 75 percent of crew members are white non-Hispanic individuals. Black non-Hispanic and Hispanic individuals account for most of the other staff.

- Language - The native language for most weatherization staff (over 95\%) is English. However, over 10 percent of staff have the ability to communicate in Spanish and some staff have the ability to communicate in other languages.

- Education - Almost all weatherization staff have at least a high school degree. And, more than one-half of auditors, almost one-half of crew chiefs, and more than one-third of crew members have taken at least some college classes.

There are some differences between the racial and ethnic background of weatherization staff and their clients. While about 15 percent of WAP clients are Black non-Hispanic individuals, only 7 percent of auditors and 9 percent of crew chiefs and crew are Black non-Hispanic. However, while 8 percent of WAP clients are Hispanic, 11 percent of crew members are Hispanic.

There also are some differences between individuals employed as weatherization staff and individuals employed by the broader construction industry. Weatherization staff have about the same age distribution and about the same percent of individuals who are Black non-Hispanic as the individuals employed in the construction industry. However, while about 9 percent of WAP crew members are Hispanic, about 25 percent of individuals in the construction industry are Hispanic. In addition, women are only 7 percent of auditors, 2 percent of crew chiefs, and 3 percent of crew, while they are 9 percent of employees in the construction industry.

\section{Weatherization Staff Employment Characteristics}

In general, the survey shows that the employees working in WAP are full-time staff who perceive that weatherization is their primary job and that their weatherization job represents a good career. They are generally satisfied with their jobs, though they perceive that the pay and benefits could be improved. But, even more, they perceive that the training and work experience that they receive as part of their employment in the weatherization program furnishes them with skills that can help them to find other employment if they were to lose their jobs in weatherization.

Some key statistics from the survey include:

- Primary Job - Even though more than 20 percent of weatherization staff have more than one employer, almost all of the interviewed staff report that weatherization is their primary job and that they work full-time or more than full-time. 
- Career - About two-thirds of auditors and crew chiefs consider weatherization to be their career; about 30 percent of auditors and crew chiefs have been working in weatherization for more than ten years. About one-half of crew members consider weatherization to be their career; about 10 percent have been working in weatherization for ten years or more.

- Income and Benefits - The median income for weatherization staff ranged from $\$ 34,500$ for auditors to $\$ 26,500$ for crew members. About 71 percent of auditors, 56 percent of crew chiefs, and 55 percent of crew have health benefits. Median income in the construction industry is about $\$ 38,400$, somewhat higher than the income for weatherization staff. About 55 percent of workers in the construction industry report that they have health benefits.

- Job Satisfaction - Weatherization staff reported a high rate of satisfaction (over 80 percent) with most aspects of their jobs. The notable exceptions were that only a little over 50 percent of staff were satisfied with their pay, health benefits, and retirement benefits.

- Workforce Development - About 40 to 50 percent of staff perceive that it is "likely" or "very likely" that they would be unemployed were it not for their weatherization job. However, more than 90 percent perceive that the training and experience that they received through the WAP program would be useful in helping them to get a job in either market-rate weatherization programs or residential construction.

The WAP program appears to furnish good quality jobs that have a high level of satisfaction and furnish valuable experience and training. The jobs do not appear to pay as well as other types of construction industry jobs.

\section{Weatherization Staff Training Experiences and Training Needs}

The WAP program invests in both on-the-job and classroom training for weatherization staff. Most staff reported that they learned the skills they need to do their job through a combination of on-the-job training and formal weatherization training while working for the weatherization program. Most weatherization staff report that they have received a significant amount of training in the last five years, but there are at least some staff who have not received training the last five years and staff who have not received training on one or more important weatherization issues and/or procedures in the last five years. The most significant barriers to training at the time of the survey (PY 2011) appeared to be logistical (i.e., training not available at the right time or place) rather than financial (i.e., funds not available for training).

Some key statistics from the survey include:

- Weatherization Skills Development - The survey asked staff to report whether they developed the skills they needed from previous non-weatherization jobs, from on-the-job training, or through formal training classes. The statistics show that staff often reported that they developed some of the needed skills "prior to entering the weatherization field." But, most of the skills they need to do their jobs were developed through on-the-job training AND formal classroom training.

- Types of Training - Almost all staff reported that they received at least some on-the-job training and formal training the past five years. Most, but not all, staff reported that they have received at least some on-the-job mentoring in the last five years. In terms of formal training, most staff reported receiving training through training centers (more than 70\%) and at their agency (more 
than 50\%). In addition, many staff (particularly auditors) attended training at statewide, regional, and national training conferences.

- Training on Weatherization Measures - Different types of staff reported different levels of training on weatherization measures. Some variations reflect the differences in staff roles (i.e., an auditor needs broader training than does a crew member); others may be related to differences in tenure (e.g., over 40 percent of crew members have two years or less of experience).

- Auditors - Most auditors reported that they have been trained on diagnostic measures $(91 \%)$, infiltration and air sealing (84\%), and insulation (76\%). The majority of auditors reported having been trained on all major weatherization measures (i.e., HVAC, Hot Water, Baseloads, and Windows/Doors).

- Crew Chiefs - Many crew chiefs reported that they have been trained on diagnostic measures (66\%), infiltration and air sealing (76\%), and insulation (73\%). Less than onehalf of crew chiefs reported receiving training on other weatherization measures.

- Crew Members - Many crew members reported that they have been trained on diagnostic measures (49\%), infiltration and air sealing (71\%), and insulation (68\%). Less than onethird of crew members reported receiving training on most other weatherization measures.

- Outstanding Training Needs on Weatherization Measures - While most staff reported training on a number of different weatherization measures, there are still many staff who have not been trained on important weatherization measures in the last five years. Examples include: 31 percent of auditors have not received training on HVAC measures in the last five years; 37 percent of crew chiefs have not received training on diagnostics in the last five years; and, 25 percent of crew members have not received training on insulation in the last five years.

- Training on Health and Safety Measures - The major health and safety topics on which the majority of staff were trained include: lead, mold and mildew, indoor air quality, and crew safety. A significant number of staff also reported receiving training on asbestos and fire safety. However, different types of staff reported different levels of training of weatherization measures. Some variations reflect the differences in staff roles (i.e., an auditor needs broader training than does a crew member); others may be related to differences in tenure (e.g., over 40 percent of crew members have two years or less of experience).

- Outstanding Training Needs on Health and Safety Measures - While most staff reported training on a number of different health and safety measures, there are still many staff who have not been trained on important health and safety topics in the last five years. Examples include: 39 percent of auditors have not received training on indoor air quality in the last five years; 23 percent of crew chiefs have not received training on crew safety in the last five years; and, 15 percent of crew members have not received training on lead in the last five years.

Staff clearly understand the need for additional training. About 60 percent of staff reported that they need certain types of training that they have not been able to get. And, among those who report the need for additional training, the most common problems are that training is not available at the right time or right place (barrier for about one-half of those reporting a need for training) compared to funding (barrier for about 30 percent of those reporting a need for training). 


\section{Weatherization Staff Perceptions of Service Delivery}

In the weatherization staff survey, auditors, crew chiefs, and crew members furnished their feedback on program service delivery from the perspective of working directly with clients and housing units. The survey responses demonstrate that there is some variation in how service delivery procedures are implemented across the program. In some cases, those differences are an outcome of differences in opinions on the best approach to weatherization (e.g., use of computerized audits vs. priority lists). But, in other cases, the differences are likely to be differences in the clients and housing stock served by the program (e.g., differences in deferral rates). Most illuminating, perhaps, is the fact that there is a significant overlap between the items on which crew chiefs and crew members report they need additional training and the items on which they perceive that the quality of their work is not up to their expected standards.

Some key statistics from the survey include:

- $\quad$ Audit and Measure Selection Procedures - Auditors listed advantages and disadvantages of computerized audits and priority lists. It was interesting to note that some auditors thought that computerized audits increased quality (e.g., gave accurate and comprehensive results), while others thought that the computerized audits detracted from quality (e.g., did not utilize auditor's common sense).

- Client Deferrals - In general, survey responses about client deferrals indicated that consistent policies were being implemented for deferrals. Most auditors reported that there was a standard policy, that deferral decisions were communicated in writing, and that deferrals were being made in a relatively small number of homes for appropriate reasons. However, almost 20 percent of auditors reported that there was not a standard policy and about 20 percent reported that clients did not receive any written notification of a deferral. It might be appropriate to ensure that standard deferral procedures are in place for 100 percent of clients audited by the program.

- Adaptive Procedures - In most weatherization agencies, auditors inspect a home and specify the weatherization measures to be installed by the crews. Most crew chiefs indicated that they installed almost all measures specified by auditors. However, because weatherization is a complex and adaptive process, most crew chiefs also indicated that they had to install measures not specified in at least some homes and that in some homes they had to go beyond standard practices to appropriately serve the home. While it seems reasonable that sometimes crew chiefs will need to use their judgment on how best to complete a weatherization job, 63 percent of crew chiefs report that they "seldom" or "never" sought clarification from auditors.

- Perceptions of Work Quality - Both crew chiefs and crew members were asked to furnish an assessment of the quality of their crew in completing weatherization tasks. Both crew chiefs and crew members gave the highest marks for the most common weatherization measures and health and safety practices. They were less likely to give high grades for those items that are performed less often. (It is important to note that many of the measures and practices on which crew chiefs and crew members gave lower ratings were issues on which they had previously noted that additional training was needed.)

- Weatherization Measures - They gave the highest self-ratings for the quality of infiltration/air sealing, insulation, and door/window installation/repair. They were less likely to give high ratings for baseload measures, HVAC, and hot water measures. 
- Health and Safety - They gave the highest ratings for general crew safety and lead. They were less likely to give high ratings for mold and mildew, asbestos, and vermiculite.

Weatherization staff appear to have a good understanding of the challenges and subtleties associated with service delivery. However, the survey responses also show that there is some opportunity to increase the consistency of service delivery in the program.

\section{Working with Clients}

Weatherization staff work directly with clients on a daily basis. The surveys asked staff to report on some of their interactions. Staff do report that they face a number of important challenges in completing their work, including clients who are difficult to work with and homes in which staff feel unsafe. However, the statistics also show that there is a significant amount of positive interactions between staff and clients that result in some important energy education for clients.

Some key statistics from the survey include:

- Language Barriers - Staff report that they face language barriers in about 4 percent of homes, and that they have difficulty finding a good solution to the barrier in about 1 percent of homes.

- Difficult Clients - On average, auditors and crew chiefs report that they have difficulty with clients in about 5 percent of homes. While this is a relatively small share of homes, in most cases it appears that they are able to find solutions that maintain the integrity of the work and the relationship with the client.

- Staff Safety - Weatherization staff report that they "feel unsafe" in about 5 to 10 percent of homes in which they work. Pets and housing unit conditions, particularly unsanitary conditions, appear to be more prevalent than client or neighborhood issues.

- Client Interactions - Staff report that they often have the opportunity to furnish informal energy education to clients, and that they regularly interact with the client's extended family and are able to furnish some informal energy education to those individuals as well.

These findings are consistent with the data presented in Table 4.11; about 90 percent of weatherization staff reported that their interactions with clients were "satisfactory" or "very satisfactory."

\section{Agency Staff vs. Contractors - Findings for Crew Chiefs}

Some weatherization agencies use in-house crews to deliver energy services, some use contractors, and some use both types of weatherization staff. About 20 percent of crew chiefs responding to the Baseline Occupant Survey were employed by contractors. In general, the survey responses show that there are some differences between agency and contractor staff. In particular, it appears that agency staff are more likely to be salaried employees who work a normal 40-hour week and receive employee benefits (e.g., health insurance and paid time off), while contractor staff are more likely to be hourly staff who work less consistently and are less likely to receive employee benefits, but who often work more hours and have a higher annual income. However, from the perspective of training, work quality, and client interactions, there appear to be far more similarities than there are differences.

Some key statistics from the survey include: 
- Demographic Characteristics - Both types of crew chiefs (i.e., agency staff and contractors) have similar demographic characteristics. One key difference is that crew chiefs employed by contractors tend to have more education that those employed by agencies.

- Employment Status - Both types of crew chiefs report that weatherization is their primary job and that they consider weatherization to be their career. The average crew chief has been employed in weatherization for more than five years.

- Income and Benefits - One important difference between agency crew chiefs and those employed by contractors is in terms of income and benefits. Agency staff are more likely to be salaried employees who get health benefits, paid time off, and retirement benefits. They also are more likely to work a 40-hour week. Contractor staff have higher pay and tend to work more hours.

- Training - Agency crew chiefs are more likely to report that they developed their weatherization skills through formal training, while contractor staff are more likely to report that they developed the skills prior to entering the field of weatherization. Both types of staff report similar incidence of training in important weatherization topics and on the need for additional training. One important barrier for contactor crew chiefs is that 19 percent report that they have to pay for their own training.

- Weatherization Services - Contractor crew chiefs are more likely to install measures not specified by the auditor and to fail to install certain measures specified by the auditor, but they are also more likely to report that they consult with auditors regarding the job scope.

- Client Interactions - Contractor crew chiefs are more likely to report language barriers and to report that some clients are difficult to work with. However, contractor crew chiefs report providing about the same amount of informal education to clients and their families as that provided by crew chiefs employed by agencies.

Based on these survey responses, it appears that both agency and contractor crew chiefs are similar on most of the important dimensions covered in this survey.

\section{Agency Staff vs. Contractors - Findings for Crew Members}

Some weatherization agencies use in-house crews to deliver energy services, some use contractors, and some use both types of weatherization staff. About 20 percent of crew members responding to the Baseline Survey were employed by contractors. The differences between agency staff and contractor staff for crew members is very similar to the differences for crew chiefs, with a few minor exceptions outlined below. Some key statistics from the survey include:

- Demographic Characteristics - Both types of crew chiefs (i.e., agency staff and contractors) have similar demographic characteristics. However, one key difference is that crew members employed by agencies are more likely to be a member of a minority group.

- Employment Status - Both types of crew members report that weatherization is their primary job and that they consider weatherization to be their career. The average agency crew member has been employed in weatherization for more two years, while the average contractor crew member has been employed in weatherization for four years.

- Income and Benefits - One important difference between agency crew members and those employed by contractors is in terms of income and benefits. Agency staff are more likely to be 
salaried employees who get health benefits, paid time off, and retirement benefits. Contractor staff have higher pay and tend to work more hours.

- Training - Agency crew members are more likely to report that they developed their weatherization skills through formal training, while contractor staff are more likely to report that they developed the skills through on-the-job training. Both types of staff report similar incidence of training in important weatherization topics, the need for additional training, and barriers to training.

Based on these survey responses, it appears that both agency and contractor crew members are similar on most of the important dimensions covered in this survey.

Lastly, it should be noted that the respondents were resurveyed in 2013 to inquire about their job status. About $29 \%$ of the respondents had left low-income weatherization by that time. Very few moved into the non-low-income home retrofit market. These results are presented in Appendix A. 


\section{INTRODUCTION}

The purpose of this report is to disseminate the findings from the Baseline Weatherization Staff Survey. This survey was conducted with agency staff and contractors who provided services under the U.S. Department of Energy's (DOE) Weatherization Assistance Program (WAP) in Program Year (PY) 2011. The interviews were conducted with three types of weatherization staff: auditors/inspectors, crew chiefs/foremen, and crew members/technicians. This report presents the findings for the three staff groups side by side so that their characteristics, experiences, and perceptions can be compared.

This is the first of two surveys that were conducted with WAP staff. The Baseline Weatherization Staff Survey collected information for a representative group of staff working in the program during PY 2011 (i.e., during the American Recovery and Reinvestment Act (ARRA) period). The Follow-Up Weatherization Staff Survey collected information on the status, experiences, and perceptions of staff during PY 2013 (i.e., in the post-ARRA period). The Follow-Up Survey examines changes in staff employment status, perceptions, and experiences.

This is one of two reports that will be completed using information from the Weatherization Staff Surveys. The full set of reports consists of:

- Baseline Weatherization Staff Survey Report

- Follow-Up Weatherization Staff Survey Report

One purpose of the Weatherization Staff Survey is to furnish DOE and other policymakers with information that helps to characterize the weatherization workforce. However, another important purpose of the Weatherization Staff Surveys is to measure and quantify the employment and workforce development nonenergy benefits associated with the WAP program. The findings from the Surveys will be used in both the Process and Impact Reports on the Program.

\subsection{NATIONAL WEATHERIZATION ASSISTANCE PROGRAM EVALUATION OVERVIEW}

WAP was created by Congress in 1976 under Title IV of the Energy Conservation and Production Act. The purpose and scope of the Program as currently stated in the Code of Federal Regulations (CFR) 10 CFR 440.1 is "to increase the energy efficiency of dwellings owned or occupied by low-income persons, reduce their total residential energy expenditures, and improve their health and safety, especially lowincome persons who are particularly vulnerable such as the elderly, persons with disabilities, families with children, high residential energy users, and households with high energy burden." (Code of Federal Regulations, 2011)

At the request of DOE, Oak Ridge National Laboratory (ORNL) developed a comprehensive plan for a national evaluation of WAP that was published in 2007. DOE furnished funding to ORNL in 2009 for a national evaluation for Program Years 2007 and 2008, with a particular emphasis on PY 2008.

ORNL subcontracted evaluation research to APPRISE Incorporated and its partners (the Energy Center of Wisconsin, Michael Blasnik and Associates, and Dalhoff Associates LLC). The Scope of Work (SOW) for the evaluation includes the following components.

- Impact Assessment - Characterization of the weatherization network and the households that are income-eligible for WAP. Measurement and monetization of the energy and nonenergy impacts of the program. Assessment of the factors associated with higher levels of energy savings, cost savings, and cost-effectiveness. 
- Process Assessment - Direct observation of how the weatherization network delivers services and assessment of how service delivery compares to national standards. Documentation of how weatherization staff and clients perceive service delivery.

- $\quad$ Special Technical Studies - Examination of the performance of the program with respect to technical issues such as air sealing, duct sealing, furnace efficiency, and refrigerators.

- $\quad$ Synthesis Study ${ }^{2}-$ Synthesis of the findings from this evaluation into a comprehensive assessment of the success of the program in meeting its goals and identification of key areas for program enhancement.

This analysis of the Weatherization Staff Surveys contributes to both the Impact Assessment and the Process Assessment.

\subsection{WEATHERIZATION STAFF SURVEY STUDY OVERVIEW}

The overarching objective of the Weatherization Staff Surveys is to develop an understanding of the staff who delivers program services to WAP clients. The survey topics include:

- Demographic Characteristics

- Employment Characteristics

- Training Received and Training Needs

- Delivery of Weatherization Services

- Perceptions of WAP Clients

The survey was conducted with a representative sample of staff who delivered services to WAP households during PY 2011. The staff sample was developed in two stages. In the first stage, a sample of 200 agencies was selected from the more than 900 agencies that were delivering services to clients in PY 2011. In the second stage, each agency was asked to furnish lists of auditors, crew chiefs, and crew members from which a sample of weatherization staff was selected. Sampled staff were sent a paper questionnaire that could be completed and returned by the survey respondent. The respondent also had the option of going on-line to complete the survey. Interviews were completed by 350 auditors, $268 \mathrm{crew}$ chiefs, and 264 crew members.

The basic purpose of the Weatherization Staff Survey is to furnish DOE and other policymakers with information to characterize the weatherization workforce. What types of individuals are employed by the WAP program? What kind of compensation and benefits do they receive? What are their perceptions of the jobs they do, the training they receive, the services they deliver, and the clients they serve? The diverse set of questions furnishes information not previously available about the men and women who work in the front lines of the WAP program.

However, another important purpose of the Weatherization Staff Surveys is to measure and quantify the employment and workforce development nonenergy benefits associated with the WAP program. Both surveys furnish information on what types of training were furnished to staff and on the perceptions of staff regarding the ways that their training could be applied in the marketplace. And, the information on changing employment status from the Follow-Up Survey will be particularly useful in terms of

\footnotetext{
2 Tonn et al. 2014. Weatherization Works - Summary of Findings from the Retrospective Evaluation of the U.S. Department of Energy's Weatherization Assistance Program. ORNL/TM-2014/338, Oak Ridge National Laboratory, Oak Ridge, Tennessee. National Laboratory, Oak Ridge, TN.
} 
documenting whether the skills developed by staff helped them to successfully navigate the changing marketplace in the Post-ARRA period.

\subsection{ORGANIZATION OF THE BASELINE OCCUPANT SURVEY REPORT}

This report consists of nine sections, including:

- Section 1 - Introduction: Furnishes an overview of the Weatherization Assistance Program Evaluation and the Weatherization Staff Survey.

- Section 2 - Methodology: Documents the sampling and data collection procedures, and compares treatment and comparison group characteristics.

- $\quad$ Section 3 - Weatherization Staff Demographics: Furnishes information on the demographic characteristics of WAP staff by job type.

- Section 4 - Weatherization Staff Employment Characteristics: Characterizes the employment status, income and benefits, and workforce development benefits of employment in the WAP program.

- Section 5 - Training: Examines three dimensions of training - what training approaches are used, what topics are included in training, and what training needs are outstanding.

- Section 6-Weatherization Service Delivery: Presents weatherization staff perceptions about how WAP services are delivered.

- $\quad$ Section 7 - Working with Clients: Shows how weatherization staff describe their interactions with WAP clients.

- Section 8 - Agency vs. Contractor Crew Chief Findings: Examines the differences between crew chiefs employed directly by WAP agencies and those employed by contractors.

- Section 9 - Agency vs. Contractor Crew Member Findings: Examines the differences between crew members employed directly by WAP agencies and those employed by contractors.

The report does not furnish information comparing agency-employed and contractor-employed auditors because almost all auditors interviewed were agency employees.

Lastly, despite the title of the report, the results of the follow-up survey conducted with the weatherization staff respondents in 2013 are also presented in this report in Appendix A. 



\section{METHODOLOGY}

The Weatherization Staff Survey was conducted with a representative sample of weatherization staff from 200 local agencies that delivered services in PY 2011. Sampled staff were asked to complete a selfadministered questionnaire that collected information on a broad range of topics, including: demographic information, employment status, training, assessment of service delivery quality, and perceptions of WAP clients. Surveys were completed by 350 auditors, 268 crew chiefs, and 264 crew members.

One purpose of the Weatherization Staff Survey is to furnish DOE and other policymakers with information that helps to characterize the weatherization workforce. However, another important purpose of the Weatherization Staff Surveys is to measure and quantify the employment and workforce development non-energy benefits associated with the WAP program. The findings from the surveys will be used in both the Process and Impact Reports on the Program.

\subsection{SAMPLE FRAME DEVELOPMENT AND SAMPLE SELECTION PROCEDURES}

The target population for the Weatherization Staff Survey was the agency staff and contractors who were engaged in the delivery of weatherization services. The survey targeted three types of staff.

- Auditors - Staff whose primary responsibility is to determine what services should be delivered to client's home.

- Crew Leaders - Staff whose primary responsibility is to supervise the delivery of weatherization services to the client's home.

- Crew Members - Staff whose primary responsibility is to install weatherization measures in the client's home.

Staff employed by weatherization agencies and staff of contractors hired by weatherization agencies were eligible for the survey.

The sample of auditors, crew leaders, and crew members was developed in the following way.

- Grantee Sample - In PY 2008, DOE distributed WAP funds to all 50 states and the District of Columbia. All of these WAP grantees were included in the sample.

- Subgrantee Sample - For purposes of the National Weatherization Assistance Program Evaluation, ORNL selected a sample of 400 subgrantees to represent the population of 905 subgrantees that received funds from grantees for PY 2008. A sub-sample of 200 of those 400 agencies were selected for the Staff Survey.

- Lists of Auditors - Each subgrantee was contacted and asked to furnish a list of staff who had completed audits in PY 2011. A sample of auditors was selected from the list furnished by each agency.

- Lists of Crew Leaders - The sampled auditors were asked to furnish the names and addresses for the crew leader for each of their six most recent jobs. In some subgrantees, the auditor does not have information on the crew leaders for their jobs. For those subgrantees, the agency manager 
was asked to furnish a list of crew leaders. A sample of crew leaders was selected from the lists provided by auditors and/or agency managers.

- Lists of Crew Members - The sampled crew leaders were asked to furnish a list for up to ten crew members who assigned to their most recent weatherization project. A sample of crew members was selected from the list provided by crew leaders.

The final staff survey sample included 517 auditors, 523 crew chiefs, and 526 crew members from 200 subgrantees.

\subsection{DATA COLLECTION PROCEDURES}

The questionnaire for the Weatherization Staff Survey was designed by staff from ORNL as part of the National Weatherization Assistance Program Evaluation Plan. The survey asked all staff about their employment history, characteristics of their current position, job satisfaction, training history, training needs, and the role of low-income weatherization in their long-term career plans. Auditors were asked questions related to audit procedures, measure selection, and deferrals. Crew chiefs were asked questions about differences between measures specified by auditors and measures installed by crews. Crew chiefs and crew members were asked questions about work quality. All staff were asked demographic questions.

Staff were given the choice of completing an on-line survey or a paper survey. About 70 percent of auditors completed the survey on paper, while over 90 percent of crew chiefs and crew members completed the survey on paper. The paper questionnaire was available in English and Spanish, while the on-line survey was only available in English.

The data collection procedures included the following:

- First Mailing - Sampled staff were mailed a survey packet that included a cover letter, the questionnaire booklet, and a prepaid business reply envelope. The cover letter explained the purpose of the survey, offered a $\$ 20$ incentive for completion, and gave the option of completing the survey on-line. Each sample staff was furnished the website URL and was assigned a unique username. The cover letter noted in Spanish that respondents would call to request a Spanishlanguage questionnaire booklet.

- First Follow-Up Call - One week after the initial mailing, non-respondents were contact by phone to confirm receipt of the survey packet and to obtain any updated contact information.

- Second Mailing - One week after the first follow-up call, a second survey packet was mailed to non-respondents.

- Second Follow-Up Call - One week after the second mailing, a second follow-up call was make to survey non-respondents.

The survey procedures yielded 350 interviews with auditors (68\% response rate), 268 interviews with crew chiefs (51\% response rate), and 264 interviews with crew members (50\% response rate). 


\section{WEATHERIZATION STAFF DEMOGRAPHICS}

This section of the report provides findings from the Baseline Survey on the demographic characteristics of weatherization staff. It examines three different dimensions for the staff working in the program.

- Demographics by Staff Type - The survey interviewed auditors, crew chiefs, and crew members. The analysis looks at the characteristics of each group and shows where there are similarities and differences.

- Comparison to Weatherization Clients - The analysis examines how the demographic profile of weatherization staff compares to the profile of their clients to assess how staff are similar to and how they are different from the clients they serve.

- Comparison to Employed Individuals - The analysis examines how the broader demographic profile of weatherization staff compares to the demographics of individuals employed in the construction industry.

In general, the statistics in this section show that the typical weatherization staff person is a white male in his forties. Individuals who are members of a racial and/or ethnic minority are represented in the population. However, racial and/or ethnic minorities are represented at higher rates in both the population of weatherization clients and in other Construction Industry jobs. Similarly, while there are some women employed as weatherization staff, they are employed at higher rates in other jobs in the construction industry.

\subsection{DEMOGRAPHICS BY JOB TITLE}

Table 3.1 shows the distribution of WAP staff by age. The median age for both auditors and crew chiefs is about 45, while it is 39 for crew members. About one-fourth of crew members are less than age 30. A small number of weatherization staff are 61 years old or older.

Table 3.1. Age by Staff Type

\begin{tabular}{|l||c||c|c|}
\hline \multicolumn{4}{|c|}{ What is your age? } \\
\hline \hline & Auditor & Chief & Member \\
\hline Number of Respondents & 350 & 268 & 264 \\
\hline \hline Up to 20 Years & $0 \%$ & $0 \%$ & $1 \%$ \\
\hline $21-30$ Years & $13 \%$ & $15 \%$ & $26 \%$ \\
\hline $31-40$ Years & $26 \%$ & $22 \%$ & $27 \%$ \\
\hline $41-50$ Years & $24 \%$ & $29 \%$ & $24 \%$ \\
\hline $51-60$ Years & $29 \%$ & $28 \%$ & $18 \%$ \\
\hline $61-70$ Years & $8 \%$ & $6 \%$ & $4 \%$ \\
\hline \hline No Answer & $0 \%$ & $1 \%$ & $1 \%$ \\
\hline \hline Total & $100 \%$ & $100 \%$ & $100 \%$ \\
\hline
\end{tabular}


Table 3.2 shows that most weatherization staff are men. The incidence of women in the audit jobs is twice what it is for crew chief and crew members, but women represent only 7 percent of all auditor staff.

Table 3.2. Gender by Staff Type

\begin{tabular}{||l||c||c|c||}
\hline \multicolumn{4}{|c|}{ What is your gender? } \\
\hline \hline & Auditor & Chief & Member \\
\hline \hline Number of Respondents & 350 & 268 & 264 \\
\hline \hline Male & $93 \%$ & $98 \%$ & $97 \%$ \\
\hline Female & $7 \%$ & $2 \%$ & $3 \%$ \\
\hline \hline No Answer & $0 \%$ & $0 \%$ & $1 \%$ \\
\hline \hline Total & $100 \%$ & $100 \%$ & $100 \%$ \\
\hline
\end{tabular}

Table 3.3 shows that most weatherization staff are white non-Hispanic individuals. One in five auditors and crew chiefs, and one in four crew are members of a racial and/or ethnic minority group.

Table 3.3. Race and Ethnicity by Staff Type

\begin{tabular}{|l|c|c|c||}
\hline \multicolumn{3}{|c||}{$\begin{array}{c}\text { Please indicate your race and ethnicity. } \\
\text { (Select all that apply) }\end{array}$} \\
\hline \hline & Auditor & Chief & Member \\
\hline \hline Number of Respondents & 350 & 268 & 264 \\
\hline \hline White & $81 \%$ & $79 \%$ & $74 \%$ \\
\hline Black or African American & $7 \%$ & $7 \%$ & $9 \%$ \\
\hline Hispanic or Latino & $6 \%$ & $7 \%$ & $11 \%$ \\
\hline American Indian or Alaska Native & $3 \%$ & $3 \%$ & $5 \%$ \\
\hline Asian & $1 \%$ & $1 \%$ & $1 \%$ \\
\hline $\begin{array}{l}\text { Native Hawaiian or Other Pacific } \\
\text { Islander }\end{array}$ & $<1 \%$ & $0 \%$ & $<1 \%$ \\
\hline \hline Refused or No Answer & $7 \%$ & $6 \%$ & $2 \%$ \\
\hline
\end{tabular}

Tables 3.4 and 3.5 furnish information on languages spoken by weatherization staff. Table 3.4 shows that English is the native language of more than 90 percent of weatherization staff. A small number of staff report that Spanish is their native language and a few report that their native language is some other language. Table 3.5 shows that more than 10 percent of staff at all levels report that they can speak Spanish at a conversational level and that 6-7 percent of staff at all levels report that they can speak another language at a conversational level. 
Table 3.4. Native Language by Staff Type

\begin{tabular}{|c|c|c|c|}
\hline \multicolumn{4}{|c|}{$\begin{array}{l}\text { Is English your native language? } \\
\text { [If no,] what is your native language? }\end{array}$} \\
\hline & Auditor & Chief & Member \\
\hline Number of Respondents & 350 & 268 & 264 \\
\hline English & $96 \%$ & $97 \%$ & $93 \%$ \\
\hline Spanish & $3 \%$ & $2 \%$ & $4 \%$ \\
\hline Other & $1 \%$ & $1 \%$ & $2 \%$ \\
\hline No Answer & $<1 \%$ & $0 \%$ & $1 \%$ \\
\hline Total & $100 \%$ & $100 \%$ & $100 \%$ \\
\hline
\end{tabular}

Table 3.5. Languages Spoken by Staff Type

\begin{tabular}{|c|c|c|c|}
\hline \multicolumn{4}{|c|}{$\begin{array}{c}\text { Is English your native language? } \\
\text { [If no,] what is your native language? } \\
\text { What languages can you speak at a conversational level? } \\
\text { [Response may have more than one code] }\end{array}$} \\
\hline & Auditor & Chief & Member \\
\hline Number of Respondents & 350 & 268 & 264 \\
\hline English & $99 \%$ & $100 \%$ & $99 \%$ \\
\hline Spanish & $13 \%$ & $11 \%$ & $12 \%$ \\
\hline Other & $7 \%$ & $6 \%$ & $6 \%$ \\
\hline No Answer & $<1 \%$ & $0 \%$ & $0 \%$ \\
\hline
\end{tabular}

Table 3.6 shows the educational level of weatherization staff. There are important differences in educational attainment by job titles. Over 20 percent of auditors reported that they had at least a Bachelor's degree and about 40 percent reported that they had completed at least an Associate's degree. In comparison, only 17 percent of crew chiefs and 15 percent of crew reported that they had completed at least an Associate's degree. 
Table 3.6. Education Level by Staff Type

\begin{tabular}{|c|c|c|c|}
\hline \multicolumn{4}{|c|}{$\begin{array}{c}\text { What is the highest level of school you have completed or the highest degree you have received? } \\
\text { (Select best option) }\end{array}$} \\
\hline & Auditor & Chief & Member \\
\hline Number of Respondents & 350 & 268 & 264 \\
\hline Did not Attend High School & $0 \%$ & $0 \%$ & $1 \%$ \\
\hline Some High School but no Diploma & $1 \%$ & $6 \%$ & $10 \%$ \\
\hline High School Diploma or Equivalent (e.g. GED) & $27 \%$ & $44 \%$ & $44 \%$ \\
\hline Some College but No Degree & $33 \%$ & $31 \%$ & $29 \%$ \\
\hline Associate Degree & $17 \%$ & $11 \%$ & $11 \%$ \\
\hline Bachelor's Degree & $18 \%$ & $5 \%$ & $4 \%$ \\
\hline Advanced College Degree & $4 \%$ & $1 \%$ & $<1 \%$ \\
\hline Prefer Not To Answer & $1 \%$ & $2 \%$ & $2 \%$ \\
\hline Total & $100 \%$ & $100 \%$ & $100 \%$ \\
\hline
\end{tabular}

\subsection{COMPARISON TO WEATHERIZATION CLIENTS}

Weatherization staff work extensively in low-income communities and with low-income clients. It is useful to consider how the demographics of weatherization staff compare to the clients that they serve. The Eligible Population Report furnishes information on the population of income-eligible households and the Baseline Occupant Survey Report furnishes information on the households served by the program in PY 2011. Table 3.7 compares the racial and ethnic distribution of staff to both eligible households and clients served by the program. Overall, the table shows that weatherization staff are less likely to be members of racial and/or ethnic minorities than their clients. For example, 7 to 9 percent of weatherization staff are Black non-Hispanic individuals, while about 15 percent of clients and 17 percent of low-income households are Black non-Hispanic. ${ }^{3}$

\footnotetext{
${ }^{3}$ In part, the difference between the demographics of WAP clients and those of low-income households are an outcome of the distribution of WAP funds. Since states in colder areas receive more WAP funds, more WAP clients are located in the Northeast and Midwest Census Regions. Those regions have fewer Black and Hispanic lowincome households than do the South and West Census Regions.
} 
Table 3.7. Race and Ethnicity by Staff Type and for Clients

\begin{tabular}{|l||c||c|c||c||c||}
\hline \multicolumn{7}{|c||}{$\begin{array}{c}\text { Please indicate your race and ethnicity. } \\
\text { (Select all that apply) }\end{array}$} \\
\hline \hline & $\begin{array}{c}\text { Cuditor } \\
\text { Chief }\end{array}$ & Member & $\begin{array}{c}\text { WAP } \\
\text { Clients* }\end{array}$ & $\begin{array}{c}\text { Low-Income } \\
\text { Households** }\end{array}$ \\
\hline \hline Number of Respondents & 350 & 268 & 264 & 662 & $35.0 \mathrm{M}$ \\
\hline White & $81 \%$ & $79 \%$ & $74 \%$ & $73 \%$ & $56 \%$ \\
\hline Black or African American & $7 \%$ & $7 \%$ & $9 \%$ & $15 \%$ & $17 \%$ \\
\hline Hispanic or Latino & $6 \%$ & $7 \%$ & $11 \%$ & $8 \%$ & $16 \%$ \\
\hline $\begin{array}{l}\text { American Indian or Alaska } \\
\text { Native }\end{array}$ & $3 \%$ & $3 \%$ & $5 \%$ & $1 \%$ & $4 \%$ \\
\hline Asian & $1 \%$ & $1 \%$ & $1 \%$ & $<1 \%$ & $1 \%$ \\
\hline $\begin{array}{l}\text { Native Hawaiian or Other } \\
\text { Pacific Islander }\end{array}$ & $<1 \%$ & $0 \%$ & $<1 \%$ & $<1 \%$ & $6 \%$ \\
\hline \hline Refused or No Answer & $7 \%$ & $6 \%$ & $2 \%$ & $2 \%$ & $0 \%$ \\
\hline
\end{tabular}

*Source: Weatherization Assistance Program Baseline Occupant Survey Report.

**Source: Weatherization Assistance Program Eligible Population Report.

However, Table 3.5 above shows that 11 to 13 percent of staff can speak Spanish at a conversational level and 6 to 7 percent of staff can speak some other language at a conversational level. The Eligible Population Report showed that about 17 percent of low-income households speak Spanish as their primary language and about 8 percent of low-income households speak another language as their primary language. So, it appears likely that weatherization staff in many areas possess the language skills needed to converse with their clients.

The annual income data in Section 4 of this report show that the economic circumstances for weatherization staff are at least comparable to those of the clients that they serve. In 2010, the poverty threshold was $\$ 11,139$ for a one-person household and $\$ 22,314$ for a four-person household. Since the income eligibility threshold for WAP was 200 percent of the poverty line, a one-person household with an income of about $\$ 22,000$ and a four-person household with an income of about $\$ 44,000$ would be eligible for WAP. The median income for auditors and crew chiefs is just over $\$ 30,000$ and for crew members is about $\$ 26,000$. Some weatherization staff could have economic circumstances that would make them eligible for program services.

Table 3.8. Age, Race/Ethnicity, and Gender by Staff Type

\begin{tabular}{||l||c|c||c|c||}
\hline \hline & Auditor & Chief & Member & $\begin{array}{c}\text { All } \\
\text { Construction* }\end{array}$ \\
\hline \hline Median Age & 45 & 45 & 39 & 41 (38 to 46) \\
\hline Black or African American & $7 \%$ & $7 \%$ & $9 \%$ & $9 \%$ \\
\hline Hispanic or Latino & $6 \%$ & $7 \%$ & $11 \%$ & $25 \%$ \\
\hline Women & $7 \%$ & $2 \%$ & $3 \%$ & $9 \%$ \\
\hline
\end{tabular}

*Source: Bureau of Labor Statistics, Current Population Survey, Data for 2012. 
The findings from the comparisons made in Table 3.8 include:

- Age - The median age for auditors and crew chiefs is a little older than the average for all individuals employed in the construction industry and the median age for crew members is a little younger. More-detailed analysis shows that the median age for first-line supervisors is 46 years compared to 45 years for weatherization crew chiefs, and that the median age for construction laborers is 38 years compared to 39 for weatherization crew members.

- Race/Ethnicity - Black or African-American individuals represented about 9 percent of all individuals employed in the construction industry, and about 9 percent of crew members and 7 percent of auditors and crew chiefs. However, 25 percent of individuals employed in the construction industry are of Hispanic origin, while only 11 percent of weatherization crew members and 7 percent of weatherization crew chiefs are of Hispanic origin. ${ }^{4}$

- Gender - About 9 percent of construction workers are women, but only 7 percent of auditors and 3 percent of crew members are women.

These findings show that weatherization staff are about the same age as other construction industry workers, but are somewhat less diverse in terms of race, ethnicity, and gender than are other construction industry workers.

\footnotetext{
${ }^{4}$ In part, the difference between the race and ethnicity of individuals employed by WAP and those employed in the overall construction industry may be explained by looking at Census Region differentials for individuals employed in the construction industry. WAP distributes more funding per household to the Northeast and Midwest Census Regions because low-income heating costs are higher in those areas. However, the share of construction industry workers who are Black is highest in the South Region and the share of construction industry workers who are Hispanic is highest in the West Region.
} 


\section{WEATHERIZATION STAFF EMPLOYMENT CHARACTERISTICS}

This section of the report provides findings from the Baseline Survey on the employment characteristics of weatherization staff. It examines four dimensions for staff working in the program.

- Employment Status - The survey documented the employment status of staff to determine whether low-income weatherization was their full-time job and to gather other information on the number hours worked and number of jobs held.

- Weatherization Career - The survey gathered information on how long staff have been involved with weatherization and whether they consider weatherization to be their long-term career.

- Income and Benefits - The survey collected information on the income and other benefits associated with employment in weatherization and assessed overall job satisfaction.

- Workforce Development - The survey asked staff to report on their job experiences and training, and whether they felt that their experiences prepared them for jobs in other industries.

In general, the statistics in this section show that the employees working in the Weatherization Assistance Program are full-time staff who perceive that weatherization is their primary job and that their weatherization job represents a good career. They are generally satisfied with their jobs, though they perceive that the pay and benefits could be improved. But, even more, they perceive that the training and work experience that they receive as part of their employment in the weatherization program furnishes them with skills that can help them to find other employment if they were to lose their jobs in weatherization.

\subsection{EMPLOYMENT STATUS}

The questions on employment status demonstrated that, for the most part, weatherization staff are fulltime staff members who work 40 hours per week and consider weatherization to be their main job and their long-term career.

- Table 4.1 shows that most weatherization staff have only one employer. However, about 20 percent of crew chiefs and crew members work for more than two employers.

- Table 4.2 shows that almost all of the staff interviewed in the Weatherization Staff Survey consider their low-income weatherization employer (either agency or contractor) to be their main job.

- Table 4.3 shows that almost all of the staff interviewed reported that they work at least full-time, and that a significant number work even more than full-time. Table 4.4 shows the number of hours usually worked by staff; a significant share of staff worked more than 40 hours per week.

These employment patterns appear to be consistent for all types of staff; auditors, crew chiefs, and crew members all appear to be working full-time doing weatherization as their primary job. 
Table 4.1. Number of Employers by Staff Type

\begin{tabular}{|l|c|c||c||}
\hline \multicolumn{3}{|c|}{ Including your weatherization employer, how many employers do you have? } \\
\hline \hline & Auditor & Chief & Member \\
\hline \hline Number of Respondents & 350 & 268 & 264 \\
\hline \hline One & $75 \%$ & $70 \%$ & $73 \%$ \\
\hline Two & $11 \%$ & $10 \%$ & $6 \%$ \\
\hline More than Two & $12 \%$ & $19 \%$ & $19 \%$ \\
\hline \hline No Answer & $2 \%$ & $1 \%$ & $2 \%$ \\
\hline \hline Total & $100 \%$ & $100 \%$ & $100 \%$ \\
\hline
\end{tabular}

Table 4.2. Weatherization Employment Status by Staff Type

\begin{tabular}{|l||c||c|c|}
\hline \multicolumn{3}{|c|}{ Is working for your current weatherization employer your main job? } \\
\hline \hline & Auditor & Chief & Member \\
\hline \hline Number of Respondents & 350 & 268 & 264 \\
\hline Yes $^{1}$ & $97 \%$ & $95 \%$ & $97 \%$ \\
\hline No & $2 \%$ & $4 \%$ & $1 \%$ \\
\hline \hline No Answer & $1 \%$ & $1 \%$ & $3 \%$ \\
\hline \hline Total & $100 \%$ & $100 \%$ & $100 \%$ \\
\hline
\end{tabular}

Table 4.3. Full-Time / Part-Time Status by Staff Type

\begin{tabular}{|l||c||c|c|}
\hline \multicolumn{4}{|c|}{ Considering all your employers, do you work full-time or part-time? } \\
\hline \hline & Auditor & Chief & Member \\
\hline \hline Number of Respondents & 350 & 268 & 264 \\
\hline \hline Full-time & $87 \%$ & $87 \%$ & $92 \%$ \\
\hline Part-time & $2 \%$ & $4 \%$ & $3 \%$ \\
\hline More than Full-time & $11 \%$ & $9 \%$ & $4 \%$ \\
\hline \hline No Answer & $0 \%$ & $<1 \%$ & $<1 \%$ \\
\hline \hline Total & $100 \%$ & $100 \%$ & $100 \%$ \\
\hline
\end{tabular}


Table 4.4. Weekly Hours Worked by Staff Type

\begin{tabular}{|c|c|c|c|}
\hline \multicolumn{4}{|c|}{ How many hours per week do you usually work at all of your jobs? } \\
\hline & Auditor & Chief & Member \\
\hline Number of Respondents & 350 & 268 & 264 \\
\hline Up to 30 & $2 \%$ & $7 \%$ & $3 \%$ \\
\hline $31-35$ & $4 \%$ & $6 \%$ & $7 \%$ \\
\hline $36-40$ & $66 \%$ & $61 \%$ & $75 \%$ \\
\hline $41-45$ & $7 \%$ & $2 \%$ & $3 \%$ \\
\hline $46-50$ & $9 \%$ & $13 \%$ & $9 \%$ \\
\hline More than 50 & $11 \%$ & $10 \%$ & $2 \%$ \\
\hline No Answer & $0 \%$ & $1 \%$ & $1 \%$ \\
\hline Total & $100 \%$ & $100 \%$ & $100 \%$ \\
\hline
\end{tabular}

\subsection{WEATHERIZATION CAREER}

Most weatherization agencies are community-based organizations that deliver weatherization and other social services to clients in their community. In addition to weatherization, many of these agencies have job training as one of their missions. One important question for the Weatherization Staff Survey was whether staff consider weatherization jobs to be their career, or whether these jobs are "stepping stones" to other types of employment.

The evidence from this survey suggests that the majority of staff working in the industry consider this weatherization job to be their long term career. For example:

- Table 4.5 shows that about two-thirds of auditors and crew chiefs, and about one-half of crew members agree with the statement that "I consider employment in low-income weatherization as my long-term career."

- Table 4.6 shows that 80 percent of auditors and 75 percent of crew chiefs have been working in low-income weatherization for at least two years, and that almost one-third of staff in those two groups have been working in the field for over 10 years. Even among crew members, over onehalf report that they have worked in low-income weatherization for at least two years.

- Finally, Table 4.7 shows that most staff report that their length of time with their current employer is similar to the length of time in low-income weatherization.

In general, the findings are consistent for the different types of staff. However, crew members are more likely to be new to the job and are somewhat less likely to perceive that this will be their long-term job. However, even for crew members, more than 50 percent agree with the statement that "I consider my current employment in low-income weatherization as my long-term career." 
Table 4.5. PY 2011 Weatherization Staff Survey Low-Income Weatherization as a Long-Term Career by Staff Type

\begin{tabular}{|l|c|c|c||}
\hline \multicolumn{3}{|c|}{ I consider my current employment in low-income weatherization as my long-term career. } \\
\hline \hline & Auditor & Chief & Member \\
\hline \hline Number of Respondents & 350 & 268 & 264 \\
\hline Strongly Agree & $32 \%$ & $33 \%$ & $22 \%$ \\
\hline Agree & $35 \%$ & $34 \%$ & $31 \%$ \\
\hline Neither Agree Nor Disagree & $23 \%$ & $25 \%$ & $31 \%$ \\
\hline Disagree & $7 \%$ & $5 \%$ & $10 \%$ \\
\hline Strongly Disagree & $3 \%$ & $1 \%$ & $5 \%$ \\
\hline No Answer & $<1 \%$ & $<1 \%$ & $1 \%$ \\
\hline \hline Total & $100 \%$ & $100 \%$ & $100 \%$ \\
\hline
\end{tabular}

Table 4.6. Years Working in Low-Income Weatherization by Staff Type

\begin{tabular}{|l|c||c|c|}
\hline \multicolumn{3}{|c|}{ How long have you been working in low-income weatherization? } \\
\hline & Auditor & Chief & Member \\
\hline Number of Respondents & 350 & 268 & 264 \\
\hline \hline Up to 2 Years & $20 \%$ & $24 \%$ & $45 \%$ \\
\hline 2-10 Years & $49 \%$ & $46 \%$ & $45 \%$ \\
\hline More than 10 Years & $31 \%$ & $29 \%$ & $9 \%$ \\
\hline No Answer & $<1 \%$ & $1 \%$ & $1 \%$ \\
\hline \hline Total & $100 \%$ & $100 \%$ & $100 \%$ \\
\hline
\end{tabular}

Table 4.7. Years Employed by Current Weatherization Employer by Staff Type

\begin{tabular}{|c|c|c|c|}
\hline \multicolumn{4}{|c|}{ How long have you been working for your current weatherization employer? } \\
\hline & Auditor & Chief & Member \\
\hline Number of Respondents & 350 & 268 & 264 \\
\hline Up to 2 Years & $23 \%$ & $22 \%$ & $45 \%$ \\
\hline 2-10 Years & $49 \%$ & $48 \%$ & $44 \%$ \\
\hline More than 10 Years & $28 \%$ & $29 \%$ & $10 \%$ \\
\hline No Answer & $0 \%$ & $<1 \%$ & $1 \%$ \\
\hline Total & $100 \%$ & $100 \%$ & $100 \%$ \\
\hline
\end{tabular}


Table 4.8 shows the length of time that staff report that they have held their current job title. Over onethird of auditors (35 percent) reported that they have been in their current job title two years or less.

Since Table 4.7 shows that only 23 percent of auditors were hired in the last two years, the implication is about 12 percent of auditors were promoted to that title in the last two years. Similarly, 36 percent of crew chiefs have been in their position for two years or less, but only 22 percent reported being hired in the last two years; 14 percent were promoted to that position. This rate of mobility may have been affected by the ARRA weatherization funding, since most agencies reported hiring a significant number of staff during that time period to ramp up production.

Table 4.8. Years with Current Job Title by Staff Type

\begin{tabular}{|l||c|c||c||}
\hline \multicolumn{3}{|c|}{ How long have you had your current job tile? } \\
\hline \hline & Auditor & Chief & Member \\
\hline Number of Respondents & 350 & 268 & 264 \\
\hline \hline Up to 2 Years & $35 \%$ & $36 \%$ & $50 \%$ \\
\hline 2-10 Years & $47 \%$ & $44 \%$ & $39 \%$ \\
\hline More than 10 Years & $17 \%$ & $20 \%$ & $9 \%$ \\
\hline \hline No Answer & $1 \%$ & $<1 \%$ & $3 \%$ \\
\hline \hline Total & $100 \%$ & $100 \%$ & $100 \%$ \\
\hline
\end{tabular}

\subsection{INCOME, BENEFITS, AND JOB SATISFACTION}

Table 4-9 shows the annual income reported by weatherization staff. The median income was about $\$ 34,500$ for auditors, $\$ 32,400$ for crew chiefs, and about $\$ 26,500$ for crew members. About one in ten auditors and crew chiefs reported that their income was greater than $\$ 50,000$.

Table 4.9. Annual Income by Staff Type

\begin{tabular}{|l|c|c|c|}
\hline \multicolumn{3}{|c|}{ What is your annual income from your weatherization job? } \\
\hline \hline & Auditor & Chief & Member \\
\hline \hline Number of Respondents & 350 & 268 & 264 \\
\hline \hline Up to $\$ 20,000$ & $5 \%$ & $6 \%$ & $13 \%$ \\
\hline$\$ 20,001-\$ 30,000$ & $25 \%$ & $32 \%$ & $52 \%$ \\
\hline$\$ 30,001-\$ 40,000$ & $37 \%$ & $31 \%$ & $22 \%$ \\
\hline$\$ 40,001-\$ 50,000$ & $15 \%$ & $12 \%$ & $6 \%$ \\
\hline$\$ 50,001$ and Over & $11 \%$ & $11 \%$ & $2 \%$ \\
\hline Refused or No Answer & $7 \%$ & $9 \%$ & $6 \%$ \\
\hline \hline Total & $100 \%$ & $100 \%$ & $100 \%$ \\
\hline \hline
\end{tabular}

Current Population Survey (CPS) data show that the median weekly earnings for all individuals who report working in the construction industry were $\$ 740$ per week. If that were annualized, it would be $\$ 38,400$ per year. That is somewhat higher than the average salaries reported by respondents to the Weatherization Staff Survey. Annualized earnings for construction industry first-line supervisors were reported to be about $\$ 53,000$, compared to median income of $\$ 32,400$ reported by crew chiefs. Annualized earnings for construction industry laborers were reported to be about $\$ 31,600$, compared to 
median income of $\$ 26,500$ for crew members. It is possible that the annual income for weatherization staff is closer to the average for the construction industry than it appears from these statistics. Since individuals employed in the construction industry do not always work full-time all year, it is possible that annual compensation for weatherization staff is closer to the value for other construction jobs.

Table 4.10 shows that over 90 percent of auditors, over 80 percent of crew chiefs, and about 75 percent of crew members have health insurance. However, while over 70 percent of auditors have health insurance provided by their current weatherization employers, only about one-half of crew chiefs and crew members get insurance from this source. The others get insurance from some other sources (e.g., benefits from a spouse's job).

Table 4.10. Health Insurance Coverage by Staff Type

\begin{tabular}{||l|c||c||c||}
\hline \multicolumn{3}{|c||}{ Do you have health insurance? } \\
\hline \multicolumn{1}{|||}{} & Auditor & Chief & Member \\
\hline \hline Number of Respondents & 350 & 268 & 264 \\
\hline \hline Yes, Current Weatherization Employer & $71 \%$ & $56 \%$ & $57 \%$ \\
\hline Yes, Other & $21 \%$ & $27 \%$ & $19 \%$ \\
\hline No & $8 \%$ & $17 \%$ & $24 \%$ \\
\hline \hline Total & $100 \%$ & $100 \%$ & $100 \%$ \\
\hline
\end{tabular}

An analysis of the provision of health benefits for other employees shows that weatherization staff compare favorably. Bureau of Labor Statistics (BLS) reports that 55 percent of workers in the Construction Industry receive health insurance benefits through their employer. The rate for weatherization auditors is considerably higher than that (71 percent) and the rate for crew chiefs and crew members is similar (56 percent and 57 percent).

Table 4.11 shows the overall job satisfaction reported by weatherization staff. In general, weatherization staff consider their jobs to be satisfactory or very satisfactory on most aspects of the job. Of particular note is the fact that 90 percent of weatherization staff find the interactions with clients to be satisfactory or very satisfactory. The lowest-rated aspects of the job are pay, retirement benefits, and health benefits. 
Table 4.11. Job Satisfaction (Ratings of Satisfactory or Very Satisfactory) by Staff Type

\begin{tabular}{|c|c|c|c|}
\hline \multicolumn{4}{|c|}{ How satisfactory are these aspects of your job weatherizing low-income houses? } \\
\hline \multirow[t]{2}{*}{ Job Aspect } & \multicolumn{3}{|c|}{ Very Satisfactory or Satisfactory } \\
\hline & Auditor & Chief & Member \\
\hline Number of Respondents & 350 & 268 & 264 \\
\hline Steady Work & $91 \%$ & $88 \%$ & $91 \%$ \\
\hline Interactions with Clients & $90 \%$ & $90 \%$ & $89 \%$ \\
\hline Dress Code & $88 \%$ & $91 \%$ & $89 \%$ \\
\hline Paid Time Off Policy & $86 \%$ & $74 \%$ & $82 \%$ \\
\hline Co-workers & $84 \%$ & $84 \%$ & $84 \%$ \\
\hline Flexibility of Work Schedule & $82 \%$ & $83 \%$ & $89 \%$ \\
\hline Job Safety & $81 \%$ & $79 \%$ & $80 \%$ \\
\hline Boss/ Supervisor(s) & $79 \%$ & $83 \%$ & $79 \%$ \\
\hline Health Benefits & $57 \%$ & $49 \%$ & $48 \%$ \\
\hline Retirement Benefits & $55 \%$ & $49 \%$ & $47 \%$ \\
\hline Pay & $49 \%$ & $59 \%$ & $55 \%$ \\
\hline
\end{tabular}

\subsection{WORKFORCE DEVELOPMENT}

The WAP program invests heavily in both on-the-job and classroom training for staff in all job types. (Note: This is covered in more detail in Section 5 of the Report.) This training has significant workforce development benefits.

Table 4.12 shows that a significant share of weatherization staff think that it would be likely or very likely that they would be unemployed if they did not have a job with their current weatherization employer (over 40 percent for all staff types). However, most staff think that the weatherization training they received (Table 4.13) and the job experiences that they have had in weatherization (Table 4.14) would be useful in helping them to find a new job. 
Table 4.12. Likelihood of Unemployment by Staff Type

How likely is it that you would be unemployed if you did not have a job with your current weatherization employer?

\begin{tabular}{|c|c|c|c|}
\hline & Auditor & Chief & Member \\
\hline Number of Respondents & 350 & 268 & 264 \\
\hline Very Likely & $25 \%$ & $24 \%$ & $28 \%$ \\
\hline Likely & $17 \%$ & $19 \%$ & $17 \%$ \\
\hline Neither Likely Nor Unlikely & $11 \%$ & $13 \%$ & $10 \%$ \\
\hline Unlikely & $21 \%$ & $18 \%$ & $17 \%$ \\
\hline Very Unlikely & $18 \%$ & $21 \%$ & $18 \%$ \\
\hline Don’t Know & $7 \%$ & $6 \%$ & $9 \%$ \\
\hline No Answer & $1 \%$ & $0 \%$ & $0 \%$ \\
\hline Total & $100 \%$ & $100 \%$ & $100 \%$ \\
\hline
\end{tabular}

Table 4.13. Value of Training for Finding a New Job by Staff Type

\begin{tabular}{|c|c|c|c|}
\hline & Auditor & Chief & Member \\
\hline Number of Respondents & 350 & 268 & 264 \\
\hline Yes & $90 \%$ & $88 \%$ & $84 \%$ \\
\hline No & $10 \%$ & $12 \%$ & $16 \%$ \\
\hline No Answer & $0 \%$ & $<1 \%$ & $<1 \%$ \\
\hline Total & $100 \%$ & $100 \%$ & $100 \%$ \\
\hline
\end{tabular}

Table 4.14. Value of Experience for Finding a New Job by Staff Type

Have you gained experience from your current low-income weatherization job that could be useful if you had to find a new job?

\begin{tabular}{|l|c||c|c|}
\hline \hline & Auditor & Chief & Member \\
\hline \hline Number of Respondents & 350 & 268 & 264 \\
\hline \hline Yes & $92 \%$ & $89 \%$ & $91 \%$ \\
\hline No & $8 \%$ & $9 \%$ & $7 \%$ \\
\hline \hline No Answer & $0 \%$ & $1 \%$ & $2 \%$ \\
\hline \hline Total & $100 \%$ & $100 \%$ & $100 \%$ \\
\hline
\end{tabular}


Tables 4.15 and 4.16 show that weatherization staff perceive that their training and on-the-job experiences would be most transferrable to jobs in residential weatherization in the non-low-income sector. However, they also perceive that the skills would be valuable in residential construction jobs, as well as in getting supervisory positions and running their own business. A smaller percentage (about one-third) perceive that their experiences would help them to get a job working in the commercial or industrial energy efficiency retrofit sector.

Table 4.15. Usefulness of Training in Other Fields and/or Jobs by Staff Type

\begin{tabular}{|c|c|c|c|}
\hline \multicolumn{4}{|c|}{ How useful could your experience from this job be for a job in the fields and job types listed below? } \\
\hline \multirow[t]{2}{*}{ Field or Job Type } & \multicolumn{3}{|c|}{ Extremely Useful or Very Useful } \\
\hline & Auditor & Chief & Member \\
\hline Number of Respondents & 350 & 268 & 264 \\
\hline Non-low-income Residential Weatherization & $70 \%$ & $66 \%$ & $65 \%$ \\
\hline General Residential Construction & $51 \%$ & $54 \%$ & $45 \%$ \\
\hline Supervisory Positions & $50 \%$ & $56 \%$ & $38 \%$ \\
\hline Running Own Business & $45 \%$ & $54 \%$ & $37 \%$ \\
\hline General Commercial and Industrial Retrofit & $33 \%$ & $34 \%$ & $32 \%$ \\
\hline
\end{tabular}

Table 4.16. Usefulness of Experience in Other Fields and/or Jobs by Staff Type

\begin{tabular}{|c|c|c|c|}
\hline \multicolumn{4}{|c|}{ How useful could your experience from this job be for a job in the fields and job types listed below? } \\
\hline \multirow[t]{2}{*}{ Field or Job Type } & \multicolumn{3}{|c|}{ Extremely Useful or Very Useful } \\
\hline & Auditor & Chief & Member \\
\hline Number of Respondents & 350 & 268 & 264 \\
\hline Non-low-income Residential Weatherization & $70 \%$ & $66 \%$ & $67 \%$ \\
\hline General Residential Construction & $49 \%$ & $54 \%$ & $49 \%$ \\
\hline Supervisory Positions & $46 \%$ & $56 \%$ & $38 \%$ \\
\hline Running Own Business & $44 \%$ & $50 \%$ & $39 \%$ \\
\hline General Commercial and Industrial Retrofit & $31 \%$ & $35 \%$ & $35 \%$ \\
\hline
\end{tabular}





\section{TRAINING}

The WAP program invests in both on-the-job and classroom training for weatherization staff. This section of the report provides findings from the Baseline Survey on weatherization staff training, including:

- Training Source - Where staff report that they learned the weatherization skills that they use in their job.

- Training Approach - What types of training staff report having received, including: on-the-job mentoring, classroom training, and conferences.

- Training Topics - The topics on which staff reported being trained and their perception of the value of that training.

- Training Needs - What additional training staff perceive that they need to allow them to effectively do their job.

The statistics in this section demonstrate the importance of training for the weatherization program and some of the unmet training needs. Most staff reported that they learned the skills they need to do their job through a combination of on-the-job training and formal weatherization training while working for the weatherization program. Most weatherization staff report that they have received a significant amount of training in the last five years, but there are at least some staff who have not received training the last five years and staff who have not received training on one or more important weatherization issues and/or procedures in the last five years. The most significant barriers to training at the time of the survey (PY 2011) appeared to be logistical (i.e., training not available at the right time or place) rather than financial (i.e., funds not available for training).

\subsection{TRAINING SOURCES}

Weatherization staff use basic skills that can be developed through other jobs and specialized skills that are more commonly developed in the context of the WAP program or, possibly, through other residential energy efficiency programs. Tables 5.1 through 5.3 furnish information on where weatherization staff report that they developed the skills that they use in their current weatherization job.

Table 5.1 shows that relatively few staff report having developed their skills prior to entering the weatherization field; 9 percent of auditors, 16 percent of crew chiefs, and 13 percent of crew members reported that they learned "most or all" of the skills that they apply prior to entering the field. More staff report that they learned "a lot" of their skills prior to entering the field. However, fewer than one-half of staff of all types reported that they learned "a lot" or "most or all" of their skills prior to entering the field. 
Table 5.1. Skills Learned Prior to Entering Weatherization Field

\begin{tabular}{|l||c|c|c|}
\hline \multicolumn{4}{|c||}{$\begin{array}{c}\text { What share of the weatherization skills you apply in your job did you learn prior to entering the } \\
\text { weatherization field? }\end{array}$} \\
\hline & Auditor & Chief & Member \\
\hline \hline Number of Respondents & 350 & 268 & 264 \\
\hline Most/All & $9 \%$ & $16 \%$ & $13 \%$ \\
\hline A Lot & $24 \%$ & $28 \%$ & $23 \%$ \\
\hline Some & $54 \%$ & $44 \%$ & $52 \%$ \\
\hline None & $11 \%$ & $12 \%$ & $11 \%$ \\
\hline No Answer & $2 \%$ & $1 \%$ & $2 \%$ \\
\hline \hline Total & $100 \%$ & $100 \%$ & $100 \%$ \\
\hline \hline
\end{tabular}

Tables 5.2 and 5.3 show that most staff report that they learned the skills that they use in weatherization through both on-the-job training and weatherization training. On-the-job training was the source of "a lot" or "most or all" of skills for 83 percent of auditors, 72 percent of crew chiefs, and 67 percent of crew members. Weatherization training was the source of "a lot" or "most or all" of skills for 75 percent of auditors, 56 percent of crew chiefs, and 53 percent of crew members. It is important to note that on-thejob and classroom training appear to be more important sources of training for auditors than for either crew chiefs or crew members.

Table 5.2. Skills Learned Through On-The-Job Training

What share of the weatherization skills you apply in your job did you learn through on-the-job training and experience?

\begin{tabular}{||l||c||c||c|}
\hline \hline & Auditor & Chief & Member \\
\hline \hline Number of Respondents & 350 & 268 & 264 \\
\hline \hline Most/All & $33 \%$ & $29 \%$ & $23 \%$ \\
\hline A Lot & $50 \%$ & $43 \%$ & $44 \%$ \\
\hline Some & $16 \%$ & $26 \%$ & $29 \%$ \\
\hline None & $1 \%$ & $2 \%$ & $3 \%$ \\
\hline No Answer & $<1 \%$ & $<1 \%$ & $1 \%$ \\
\hline \hline Total & $100 \%$ & $100 \%$ & $100 \%$ \\
\hline
\end{tabular}


Table 5.3. Skills Learned Through Weatherization Training

\begin{tabular}{|c|c|c|c|}
\hline \multicolumn{4}{|c|}{$\begin{array}{c}\text { What share of the weatherization skills you apply in your job did you learn in formal weatherization } \\
\text { training (classes, workshops, etc.)? }\end{array}$} \\
\hline & Auditor & Chief & Member \\
\hline Number of Respondents & 350 & 268 & 264 \\
\hline Most/All & $29 \%$ & $22 \%$ & $17 \%$ \\
\hline A Lot & $46 \%$ & $34 \%$ & $36 \%$ \\
\hline Some & $21 \%$ & $37 \%$ & $34 \%$ \\
\hline None & $3 \%$ & $6 \%$ & $12 \%$ \\
\hline No Answer & $1 \%$ & $<1 \%$ & $<1 \%$ \\
\hline Total & $100 \%$ & $100 \%$ & $100 \%$ \\
\hline
\end{tabular}

\subsection{TRAINING APPROACH}

Most weatherization staff reported receiving on-the-job training, on-the-job mentoring, and other formal weatherization training.

Table 5.4 shows that 74 percent of auditors, 62 percent of crew chiefs, and 63 percent of crew members have received "a great deal" or "quite a bit" of on-the-job training in the past five years.

Table 5.5 shows that 40 percent of auditors, 36 percent of crew chiefs, and 34 percent of crew members received "a great deal" or "quite a bit" of on-the-job mentoring in the last five years.

Table 5.6 shows that 99 percent of auditors, 97 percent of crew chiefs, and 91 percent of crew members have received formal training at least once in the last five years.

These statistics demonstrate that the WAP program furnishes all types of training to staff, both on the job and through formal training sessions.

Table 5.4. Amount of On-The-Job Training

\begin{tabular}{|l||c|c|c||}
\hline \hline \multicolumn{1}{|c|}{ How much weatherization-related 'on-the-job' training have you had during the past five years? } \\
\hline \hline & Auditor & Chief & Member \\
\hline \hline Number of Respondents & 350 & 268 & 264 \\
\hline \hline A Great Deal & $34 \%$ & $23 \%$ & $23 \%$ \\
\hline Quite a Bit & $40 \%$ & $39 \%$ & $40 \%$ \\
\hline Some & $20 \%$ & $29 \%$ & $29 \%$ \\
\hline Not Much & $4 \%$ & $6 \%$ & $6 \%$ \\
\hline None at All & $1 \%$ & $2 \%$ & $2 \%$ \\
\hline \hline No Answer & $1 \%$ & $1 \%$ & $1 \%$ \\
\hline Total & $100 \%$ & $100 \%$ & $100 \%$ \\
\hline
\end{tabular}


Table 5.5. Amount of On-The-Job Career Mentoring

\begin{tabular}{|l|c|c|c|}
\hline \multicolumn{2}{|c|}{ How much weatherization-related career mentoring have you had during the past five years? } \\
\hline \hline & Auditor & Chief & Member \\
\hline \hline Number of Respondents & 350 & 268 & 264 \\
\hline \hline A Great Deal & $16 \%$ & $11 \%$ & $8 \%$ \\
\hline Quite a Bit & $24 \%$ & $25 \%$ & $26 \%$ \\
\hline Some & $35 \%$ & $37 \%$ & $38 \%$ \\
\hline Not Much & $16 \%$ & $18 \%$ & $19 \%$ \\
\hline None at All & $8 \%$ & $9 \%$ & $8 \%$ \\
\hline No Answer & $<1 \%$ & $<1 \%$ & $1 \%$ \\
\hline \hline Total & $100 \%$ & $100 \%$ & $100 \%$ \\
\hline
\end{tabular}

Table 5.6. One or More Types of Formal Weatherization Training

\begin{tabular}{||l||c||c||c||}
\hline \multicolumn{4}{|c|}{ Which types of formal training have you received in the past five years? } \\
\hline \hline & Auditor & Chief & Member \\
\hline Number of Respondents & 350 & 268 & 264 \\
\hline Selected One or More Types & $99 \%$ & $97 \%$ & $91 \%$ \\
\hline Selected "None of These" & $1 \%$ & $3 \%$ & $9 \%$ \\
\hline Total & $100 \%$ & $100 \%$ & $100 \%$ \\
\hline
\end{tabular}

Almost all weatherization staff report that they have received many different types of training. Table 5.7 shows that most auditors have received classroom training at training centers ( 86 percent) and agencies (60 percent). But a significant share also attended state, regional, and national conferences (about 40 percent for each). For each type of training, crew chiefs and crew members reported lower attendance rates than did auditors. But, 78 percent of crew chiefs and 70 percent of crew members reported receiving classroom training at a training center, and more than one-half of each group reported receiving classroom training at an agency. A significant share of crew chiefs and crew members reported going to a state weatherization conference and a national weatherization conference. 
Table 5.7. Types of Formal Training in Last Five Years

\begin{tabular}{|l|c|c|c||}
\hline \multicolumn{3}{|c|}{ Which of the following types of formal training have you attended in the last five years? } \\
\hline & Auditor & Chief & Member \\
\hline \hline Number of Respondents & 350 & 268 & 264 \\
\hline \hline Classroom Training at a Training Center & $86 \%$ & $78 \%$ & $70 \%$ \\
\hline Classroom Training at Agency & $60 \%$ & $58 \%$ & $51 \%$ \\
\hline State's Weatherization Conference & $43 \%$ & $27 \%$ & $20 \%$ \\
\hline $\begin{array}{l}\text { National Weatherization Training } \\
\text { Conference }\end{array}$ & $42 \%$ & $31 \%$ & $23 \%$ \\
\hline Webcast & $40 \%$ & $15 \%$ & $9 \%$ \\
\hline Regional Weatherization Conference & $34 \%$ & $23 \%$ & $12 \%$ \\
\hline Affordable Comfort Conference & $33 \%$ & $13 \%$ & $4 \%$ \\
\hline BPI Certification Training [Volunteered] & $5 \%$ & $3 \%$ & $2 \%$ \\
\hline Health and Safety & $0 \%$ & $6 \%$ & $4 \%$ \\
\hline Other & $9 \%$ & $6 \%$ & $3 \%$ \\
\hline None of These & $1 \%$ & $3 \%$ & $9 \%$ \\
\hline
\end{tabular}

\subsection{TRAINING TOPICS}

The Weatherization Staff Survey asked staff to report on three different sets of training topicsweatherization skills and procedures, health and safety measures, and professional development. The survey also asked staff about the housing unit types for which they received training. The survey shows that many weatherization staff have been trained on multiple topics. However, the survey also shows that some weatherization staff have not been trained on certain topics in the last five years.

Table 5.8a shows the percentage of staff by type who received training for a number of important weatherization skills in the last five years. This table shows whether the survey respondent reported being trained on these topics for any building type. Tables 5.9a through 5.9c show the percentage of staff who reported being trained for each building type.

Table 5.8a shows that, for all staff types, most staff have received training on infiltration/air sealing and on insulation. Since these are the most commonly installed measures, it seems appropriate that most staff have received this training. However, it is somewhat of a concern that 13 percent of auditors, 23 percent of crew chiefs, and 26 percent of crew members have not been trained in infiltration and air sealing in the last five years. However, Table 5.8b furnishes a comparison of the training topics to staff tenure. It shows that staff members with 2 to 10 years of experience have the highest rate of training on infiltration and air sealing. Staff with 10 or more years of experience might actually have less need for training and may be the ones responsible for furnishing training. Staff with less than 2 years of experience might have not yet been trained. 
Table 5.8a. Formal Training Topics in Last Five Years - Any Building Type

\begin{tabular}{||l||c|c|c||}
\hline \multicolumn{3}{||c}{$\begin{array}{c}\text { On which weatherization topics have you received formal training in the past five years? } \\
\text { (Select all that apply) }\end{array}$} \\
\cline { 2 - 4 } Weatherization Topic & \multicolumn{3}{c||}{ Any Building Type } \\
\hline \hline Number of Respondents & 350 & 268 & 264 \\
\hline \hline Diagnostic Testing and Assessment Procedures & $91 \%$ & $63 \%$ & $49 \%$ \\
\hline Infiltration / Air Sealing Measures & $87 \%$ & $77 \%$ & $74 \%$ \\
\hline Insulation & $84 \%$ & $79 \%$ & $75 \%$ \\
\hline Space Heating, Ventilation, Air Conditioning & $69 \%$ & $40 \%$ & $30 \%$ \\
\hline Base Loads (e.g., Lighting, Refrigerators) & $67 \%$ & $33 \%$ & $23 \%$ \\
\hline Hot Water Heating & $59 \%$ & $27 \%$ & $28 \%$ \\
\hline Doors and Window Installation / Repair & $47 \%$ & $52 \%$ & $58 \%$ \\
\hline \hline
\end{tabular}

Table 5.8b. Training on Infiltration/Air Sealing in Last Five Years - Any Building Type

\begin{tabular}{|l||c|c|c||}
\hline \multicolumn{4}{|c||}{$\begin{array}{c}\text { Received Training on Infiltration/Air Sealing in Last Five Years } \\
\text { (Select all that apply) }\end{array}$} \\
\hline \hline \multirow{2}{*}{ Low-Income Weatherization Experience } & Auditor & Any Building Type \\
\cline { 2 - 4 } Chief & Member \\
\hline \hline Number of Respondents & 350 & 268 & 264 \\
\hline \hline Less than 2 years & $89 \%$ & $64 \%$ & $73 \%$ \\
\hline 2 to less than 5 years & $90 \%$ & $88 \%$ & $77 \%$ \\
\hline 5 to less than 10 years & $93 \%$ & $81 \%$ & $79 \%$ \\
\hline 10 years or more & $80 \%$ & $74 \%$ & $64 \%$ \\
\hline \hline
\end{tabular}

Table 5.8 shows that Auditors are trained more broadly than are crew chiefs and crew members. While most staff of all types receive training on infiltration/air sealing and insulation, a much higher share of auditors receive training on HVAC, Base Loads, Hot Water Heaters, and Door and Window installation and/or repair. Since many agencies use specialty contractors for HVAC and Water Heating, it makes sense that auditors would need to be trained on those measures to do an assessment of the home, but that weatherization crew members might not need training on those issues.

Tables 5.9a through 5.9c show the housing unit types on which staff received training. Single family homes represent the largest share of homes treated by the program (53 percent in PY 2008) and most staff report that they were trained on this building type. However, the majority of staff reported receiving training on infiltration/air sealing and insulation for mobile homes, and about one-half of staff reported receiving training on these topics for multi-family homes. 
Table 5.9a. Formal Training Topics in Last Five Years - Single Family Homes

\begin{tabular}{||l|c|c|c||}
\hline \multicolumn{3}{|c|}{$\begin{array}{c}\text { On which weatherization topics have you received formal training in the past five years? } \\
\text { (Select all that apply) }\end{array}$} \\
\cline { 2 - 4 } \multirow{2}{*}{ Weatherization Topic } & \multicolumn{3}{c||}{ Single Family } \\
\hline \hline Number of Respondents & 350 & 268 & 264 \\
\hline \hline Infiltration / Air Sealing Measures & $84 \%$ & $76 \%$ & $71 \%$ \\
\hline Insulation & $76 \%$ & $73 \%$ & $68 \%$ \\
\hline Space Heating, Ventilation, Air Conditioning & $67 \%$ & $38 \%$ & $28 \%$ \\
\hline Base Loads (e.g., Lighting, Refrigerators) & $66 \%$ & $33 \%$ & $22 \%$ \\
\hline Hot Water Heating & $57 \%$ & $26 \%$ & $28 \%$ \\
\hline Doors and Window Installation / Repair & $46 \%$ & $50 \%$ & $56 \%$ \\
\hline
\end{tabular}

Table 5.9b. Formal Training Topics in Last Five Years - Mobile Homes

\begin{tabular}{|l||c|c|c||}
\hline \multicolumn{2}{|c|}{$\begin{array}{c}\text { On which weatherization topics have you received formal training in the past five years? } \\
\text { (Select all that apply) }\end{array}$} \\
\cline { 2 - 4 } \multirow{2}{*}{ Weatherization Topic } & Muditor & Chief & Member \\
\hline \hline Number of Respondents & 350 & 268 & 264 \\
\hline \hline Infiltration / Air Sealing Measures & $60 \%$ & $56 \%$ & $60 \%$ \\
\hline Insulation & $62 \%$ & $64 \%$ & $61 \%$ \\
\hline Space Heating, Ventilation, Air Conditioning & $50 \%$ & $29 \%$ & $25 \%$ \\
\hline Base Loads (e.g., Lighting, Refrigerators) & $48 \%$ & $26 \%$ & $18 \%$ \\
\hline Hot Water Heating & $43 \%$ & $22 \%$ & $23 \%$ \\
\hline Doors and Window Installation / Repair & $35 \%$ & $43 \%$ & $48 \%$ \\
\hline \hline
\end{tabular}

Table 5.9c. Formal Training Topics in Last Five Years - Multifamily

\begin{tabular}{||l||c|c|c||}
\hline \multicolumn{2}{|c|}{$\begin{array}{c}\text { On which weatherization topics have you received formal training in the past five years? } \\
\text { (Select all that apply) }\end{array}$} \\
\cline { 2 - 4 } \multirow{2}{*}{ Weatherization Topic } & Muditor & Chief & Member \\
\hline \hline Number of Respondents & 350 & 268 & 264 \\
\hline \hline Infiltration / Air Sealing Measures & $44 \%$ & $52 \%$ & $57 \%$ \\
\hline Insulation & $43 \%$ & $50 \%$ & $53 \%$ \\
\hline Space Heating, Ventilation, Air Conditioning & $32 \%$ & $24 \%$ & $21 \%$ \\
\hline Base Loads (e.g., Lighting, Refrigerators) & $35 \%$ & $21 \%$ & $22 \%$ \\
\hline Hot Water Heating & $30 \%$ & $16 \%$ & $21 \%$ \\
\hline Doors and Window Installation / Repair & $27 \%$ & $37 \%$ & $45 \%$ \\
\hline
\end{tabular}


Table 5.10 shows the health and safety topics on which weatherization staff were trained in the last five years. Almost all staff reported receiving training on lead safety in the last five years. For auditors, training on mold and mildew and indoor air quality were the next most common health and safety training topics; more than 60 percent of staff received this training in the last five years. For crew chiefs and crew members, crew safety was the second most common health and safety training topic; more than 70 percent of staff reported receiving this training in the last five years. As with the weatherization topics, while these high rates of training show that the program does a lot of training, there is concern that some staff do not report being trained on some important topics in the last five years. For example, 39 percent of auditors and 52 percent of crew chiefs did not report that they received training on indoor air quality in the last five years. About 60 percent of staff of all types did not report that they received training on asbestos in the last five years.

Table 5.10. Training on Health and Safety Topics in Last Five Years

\begin{tabular}{|c|c|c|c|}
\hline \multicolumn{4}{|c|}{$\begin{array}{c}\text { On which health and safety topics have you received training in the past five years? } \\
\text { (Select all that apply) }\end{array}$} \\
\hline & Auditor & Chief & Member \\
\hline Number of Respondents & 350 & 268 & 264 \\
\hline Lead & $87 \%$ & $96 \%$ & $85 \%$ \\
\hline Mold and Mildew & $63 \%$ & $54 \%$ & $52 \%$ \\
\hline Indoor Air Quality & $61 \%$ & $48 \%$ & $42 \%$ \\
\hline General Crew Safety & $49 \%$ & $73 \%$ & $72 \%$ \\
\hline Asbestos & $41 \%$ & $39 \%$ & $44 \%$ \\
\hline Fire Safety & $29 \%$ & $31 \%$ & $32 \%$ \\
\hline $\begin{array}{l}\text { OSHA Training } \\
\text { [Volunteered] }\end{array}$ & $5 \%$ & $4 \%$ & $5 \%$ \\
\hline Other & $4 \%$ & $2 \%$ & $4 \%$ \\
\hline None of These & $1 \%$ & $1 \%$ & $6 \%$ \\
\hline No Answer & $6 \%$ & $1 \%$ & $2 \%$ \\
\hline
\end{tabular}

Table 5.11 shows what other types of professional development training staff received. Auditors were much more likely than crew chiefs and crew members to receive this type of training. The most common type of training for auditors was training in audit techniques for single family homes, mobile homes, and multifamily buildings. However, many auditors also received training in client education and monitoring/quality control procedures. Some crew chiefs and crew members also received training in auditing, client education, and monitoring/quality control. 
Table 5.11. Professional Development Training in Last Five Years

\begin{tabular}{|c|c|c|c|}
\hline \multicolumn{4}{|c|}{$\begin{array}{c}\text { On which topics have you had professional development training in the past five years that could take you to the } \\
\text { next level in your weatherization career? } \\
\text { (Select all that apply) }\end{array}$} \\
\hline & Auditor & Chief & Member \\
\hline Number of Respondents & 350 & 268 & 264 \\
\hline $\begin{array}{l}\text { Auditing / Estimating for Single Family } \\
\text { Dwellings }\end{array}$ & $69 \%$ & $33 \%$ & $19 \%$ \\
\hline Auditing / Estimating for Mobile Homes & $49 \%$ & $21 \%$ & $16 \%$ \\
\hline Client Education & $41 \%$ & $26 \%$ & $25 \%$ \\
\hline Monitoring / Quality Control & $37 \%$ & $23 \%$ & $13 \%$ \\
\hline $\begin{array}{l}\text { Auditing / Estimating for Multifamily } \\
\text { Dwellings }\end{array}$ & $36 \%$ & $17 \%$ & $13 \%$ \\
\hline Management & $18 \%$ & $23 \%$ & $10 \%$ \\
\hline Outreach and Communications & $16 \%$ & $12 \%$ & $9 \%$ \\
\hline Financial Topics & $9 \%$ & $9 \%$ & $3 \%$ \\
\hline Other & $3 \%$ & $3 \%$ & $3 \%$ \\
\hline None of These & $16 \%$ & $39 \%$ & $54 \%$ \\
\hline No Answer & $1 \%$ & $3 \%$ & $3 \%$ \\
\hline
\end{tabular}

Table 5.12 shows what professional certifications staff reported that they have received. For all types of staff, training on lead-safe procedures appears to be a priority; 43 percent of auditors, 57 percent of crew chiefs, and 39 percent of crew members have both lead-safe weatherization training and certification as a lead-certified renovator. (Note: Each weatherization crew is required to have at least one person with both certifications on the job.) About one-half of auditors have BPI Building Analyst certification. Only about one in five crew chiefs and one in ten crew members have that certification. Relatively few weatherization staff of all types have other listed certifications. 
Table 5.12. Professional Certifications Received

\begin{tabular}{|l|c|c||c|}
\hline \multicolumn{3}{|c|}{$\begin{array}{c}\text { What national professional certifications do you have? } \\
\text { (Select all that apply) }\end{array}$} \\
\hline \hline & Auditor & Chief & Member \\
\hline \hline Number of Respondents & 350 & 268 & 264 \\
\hline Lead Safe Weatherization & $63 \%$ & $74 \%$ & $62 \%$ \\
\hline Lead Certified Renovator & $59 \%$ & $72 \%$ & $50 \%$ \\
\hline BPI Building Analyst & $51 \%$ & $19 \%$ & $12 \%$ \\
\hline BPI Envelope & $18 \%$ & $9 \%$ & $5 \%$ \\
\hline BPI Heating & $14 \%$ & $4 \%$ & $3 \%$ \\
\hline BPI Manufactured Housing & $8 \%$ & $4 \%$ & $3 \%$ \\
\hline $\begin{array}{l}\text { Residential Building Envelope Whole House } \\
\text { Air Leakage Control Crew Chief }\end{array}$ & $6 \%$ & $10 \%$ & $3 \%$ \\
\hline HERS & $5 \%$ & $2 \%$ & $<1 \%$ \\
\hline BPI Multifamily & $4 \%$ & $1 \%$ & $0 \%$ \\
\hline $\begin{array}{l}\text { BPI Residential Building Envelope } \\
\text { Accessible Areas Air Leakage Control }\end{array}$ & $3 \%$ & $5 \%$ & $3 \%$ \\
\hline LEED & $2 \%$ & $1 \%$ & $2 \%$ \\
\hline BPI Air Conditioning and Heat Pump & $1 \%$ & $1 \%$ & $1 \%$ \\
\hline NAHB Green Building & $1 \%$ & $<1 \%$ & $0 \%$ \\
\hline None of These & $7 \%$ & $7 \%$ & $21 \%$ \\
\hline \hline No Answer & $<1 \%$ & $<1 \%$ & $2 \%$ \\
\hline \hline
\end{tabular}

\subsection{TRAINING NEEDS}

The previous section showed that many weatherization staff received training on a number of different topics in a number of different ways. However, the previous section also showed that some staff have not received training on important topics in the last five years. The tables in this section show what types of training weatherization staff reported that they need but have not been able to get.

Table 5.13 shows that 55 percent of auditors, 59 percent of crew chiefs, and 62 percent of crew members reported that they need certain types of training that they have not been able to get. Tables 5.14a through $5.14 \mathrm{c}$ show the weatherization skills in which staff report that they could use more training by housing unit type. For most staff types, training topics, and buildings types, about 10 to 20 percent of staff report that they need additional training. The reported need for training appears to be a little higher for specialized areas, such as HVAC and Water Heating equipment. It appears to be a little lower for the more-targeted weatherization skills related to infiltration/air sealing and insulation. In addition, crew members are more likely to report that they need training than do auditors and crew chiefs.

\footnotetext{
${ }^{5}$ It should be noted that Lead Safe Weatherization is technically not a national certification; however, within this industry it appears that weatherization staff perceive that infield training on lead safe weatherization is considered equivalent to a certification.
} 
Table 5.13. Any Training Needed but Not Received

\begin{tabular}{||l|c||c|c||}
\hline \multicolumn{3}{|c|}{ Is there training you think you need in your current job, but have not been able to get? } \\
\hline \hline & Auditor & Chief & Member \\
\hline \hline Number of Respondents & 350 & 268 & 264 \\
\hline \hline Yes & $55 \%$ & $59 \%$ & $62 \%$ \\
\hline No & $41 \%$ & $40 \%$ & $37 \%$ \\
\hline \hline No Answer & $4 \%$ & $1 \%$ & $1 \%$ \\
\hline \hline Total & $100 \%$ & $100 \%$ & $100 \%$ \\
\hline
\end{tabular}

Table 5.14a. Topics on Which Training Is Needed - Single Family Homes

\begin{tabular}{|l||c|c|c||}
\hline \hline \multirow{2}{*}{$\begin{array}{c}\text { In what areas do you feel more training would be useful in your current weatherization job? } \\
\text { (Select all that apply) }\end{array}$} \\
\cline { 2 - 4 } \multirow{2}{*}{ Weatherization Topic } & \multicolumn{3}{|c||}{ Single Family } \\
\cline { 2 - 4 } & Auditor & Chief & Member \\
\hline \hline Number of Respondents & 350 & 268 & 264 \\
\hline \hline Space Heating, Ventilation, Air Conditioning & $18 \%$ & $16 \%$ & $24 \%$ \\
\hline Hot Water Heating & $12 \%$ & $15 \%$ & $21 \%$ \\
\hline Doors and Window Installation / Repair & $11 \%$ & $8 \%$ & $14 \%$ \\
\hline Base Loads (e.g., Lighting, Refrigerators) & $11 \%$ & $14 \%$ & $21 \%$ \\
\hline Auditing / Estimating & $11 \%$ & $25 \%$ & $25 \%$ \\
\hline Infiltration / Air Sealing Measures & $7 \%$ & $8 \%$ & $13 \%$ \\
\hline Insulation & $5 \%$ & $6 \%$ & $12 \%$ \\
\hline
\end{tabular}

Table 5.14b. Topics on Which Training Is Needed - Mobile Homes

\begin{tabular}{|l||c|c|c||}
\hline \multicolumn{1}{|c|}{ In what areas do you feel more training would be useful in your current weatherization job? } \\
\hline \hline \multirow{2}{*}{ Weatherization Topic } & Muditor & Chief & Member \\
\cline { 2 - 4 } & 350 & 268 & 264 \\
\hline \hline Number of Respondents & $12 \%$ & $12 \%$ & $21 \%$ \\
\hline \hline Space Heating, Ventilation, Air Conditioning & $9 \%$ & $12 \%$ & $17 \%$ \\
\hline Hot Water Heating & $8 \%$ & $8 \%$ & $13 \%$ \\
\hline Doors and Window Installation / Repair & $9 \%$ & $13 \%$ & $19 \%$ \\
\hline Base Loads (e.g., Lighting, Refrigerators) & $8 \%$ & $21 \%$ & $21 \%$ \\
\hline Auditing / Estimating & $7 \%$ & $8 \%$ & $13 \%$ \\
\hline Infiltration / Air Sealing Measures & $9 \%$ & $9 \%$ & $11 \%$ \\
\hline Insulation & & & \\
\hline
\end{tabular}


Table 5.14c. Topics on Which Training Is Needed - Multifamily Homes

\begin{tabular}{|l|c|c|c||}
\hline \multicolumn{2}{||}{$\begin{array}{c}\text { In what areas do you feel more training would be useful in your current weatherization job? } \\
\text { (Select all that apply) }\end{array}$} \\
\cline { 2 - 4 } \multirow{2}{*}{ Weatherization Topic } & \multicolumn{3}{|c||}{ Multifamily } \\
\hline \hline Number of Respondents & 350 & 268 & 264 \\
\hline \hline Space Heating, Ventilation, Air Conditioning & $16 \%$ & $15 \%$ & $20 \%$ \\
\hline Hot Water Heating & $13 \%$ & $13 \%$ & $17 \%$ \\
\hline Doors and Window Installation / Repair & $11 \%$ & $9 \%$ & $13 \%$ \\
\hline Base Loads (e.g., Lighting, Refrigerators) & $11 \%$ & $12 \%$ & $18 \%$ \\
\hline Auditing / Estimating & $17 \%$ & $21 \%$ & $21 \%$ \\
\hline Infiltration / Air Sealing Measures & $13 \%$ & $10 \%$ & $13 \%$ \\
\hline Insulation & $12 \%$ & $8 \%$ & $12 \%$ \\
\hline \hline
\end{tabular}

Table 5.15 shows what training on specialized weatherization issues staff perceive would be useful in their current weatherization jobs. About one in five staff indicated that they needed additional training in asbestos, indoor air quality, mold and mildew, and diagnostic testing and assessment procedures. In general, the responses were consistent across the different types of staff, though a slightly higher percentage of crew members indicated a need for additional training.

Table 5.15. Specialized Issues on Which Training Is Needed

\begin{tabular}{||l||c||c||c||}
\hline \multicolumn{3}{|c|}{ In what areas do you feel more training would be useful in your current weatherization job? } \\
\hline \hline & Auditor & Chief & Member \\
\hline \hline Number of Respondents & 350 & 268 & 264 \\
\hline Asbestos & $24 \%$ & $25 \%$ & $29 \%$ \\
\hline Indoor Air Quality & $21 \%$ & $18 \%$ & $22 \%$ \\
\hline Mold and Mildew & $21 \%$ & $25 \%$ & $26 \%$ \\
\hline Diagnostic Testing and Assessment Procedures & $19 \%$ & $19 \%$ & $29 \%$ \\
\hline Fire Safety & $16 \%$ & $16 \%$ & $18 \%$ \\
\hline Client Education & $16 \%$ & $15 \%$ & $18 \%$ \\
\hline Lead & $12 \%$ & $13 \%$ & $19 \%$ \\
\hline General Crew Safety & $7 \%$ & $7 \%$ & $19 \%$ \\
\hline Other & $7 \%$ & $12 \%$ & $13 \%$ \\
\hline \hline
\end{tabular}

Table 5.16 shows why staff perceive that they have not been able to get the training that they need. The most commonly listed barriers to training are that training "is not available at the right times" and that training "is not available at the right places." A relatively small share of staff ( 8 percent to 15 percent) report that lack of training funds is a barrier to getting training they need. 
Table 5.16. Reasons for Unmet Training Needs

\begin{tabular}{|c|c|c|c|}
\hline \multicolumn{4}{|c|}{$\begin{array}{l}\text { What has kept your training needs from being met in the last five years? } \\
\text { (Select all that apply) }\end{array}$} \\
\hline & Auditor & Chief & Member \\
\hline Number of Respondents & 350 & 268 & 264 \\
\hline Training Not Available at the Right Times & $19 \%$ & $18 \%$ & $16 \%$ \\
\hline Training Not Available at the Right Places & $14 \%$ & $10 \%$ & $8 \%$ \\
\hline Lack of Training Funds & $13 \%$ & $15 \%$ & $8 \%$ \\
\hline $\begin{array}{l}\text { Not Aware of Training Opportunities that Meet Training } \\
\text { Needs }\end{array}$ & $13 \%$ & $14 \%$ & $15 \%$ \\
\hline Available Training is Poor in Quality & $6 \%$ & $3 \%$ & $1 \%$ \\
\hline Management Does Not Support Training [Volunteered] & $4 \%$ & $3 \%$ & $2 \%$ \\
\hline Too Busy / Need to Meet Production [Volunteered] & $4 \%$ & $0 \%$ & $0 \%$ \\
\hline Not Senior Enough & $3 \%$ & $4 \%$ & $8 \%$ \\
\hline Haven't Asked for the Training & $3 \%$ & $5 \%$ & $8 \%$ \\
\hline Have to Pay for Own Training & $2 \%$ & $6 \%$ & $2 \%$ \\
\hline Other & $1 \%$ & $2 \%$ & $3 \%$ \\
\hline None of These & $4 \%$ & $8 \%$ & $9 \%$ \\
\hline Don't Know & $3 \%$ & $6 \%$ & $8 \%$ \\
\hline No Answer & $3 \%$ & $4 \%$ & $2 \%$ \\
\hline Not Applicable & $41 \%$ & $40 \%$ & $38 \%$ \\
\hline
\end{tabular}

The survey also asked weatherization crew chiefs and crew members to report on whether the weatherization crew "as a team" has the skills needed to perform "all of the weatherization tasks" they need to complete. Table 5.17 shows that crew chiefs feel positively about their crews; 62 percent "strongly agree" with that statement and 31 percent "agree" with that statement. Crew members had slightly lower levels of confidence in their teams; 54 percent "strongly agree" with that statement and 34 percent "agree" with that statement.

Table 5.17. Ability of Crew to Meet Weatherization Requirements

\begin{tabular}{|l|c|c||}
\hline \multicolumn{2}{|c||}{$\begin{array}{c}\text { Please indicate your level of agreement/disagreement with the following statement: “As a team, my crew has } \\
\text { sufficient knowledge to perform all the weatherization tasks we need to complete." }\end{array}$} \\
\hline \multicolumn{1}{|c|}{ Chief } & Member \\
\hline \hline Number of Respondents & 268 & 264 \\
\hline \hline Strongly Agree & $62 \%$ & $54 \%$ \\
\hline Agree & $31 \%$ & $34 \%$ \\
\hline Neither Agree nor Disagree & $3 \%$ & $7 \%$ \\
\hline Disagree & $2 \%$ & $2 \%$ \\
\hline \hline Not Applicable or No Answer & $1 \%$ & $2 \%$ \\
\hline \hline Total & $100 \%$ & $100 \%$ \\
\hline
\end{tabular}


However, the survey also asked crew chiefs and crew members the topics on which their weatherization team needed a lot of additional training. While only about 20 percent of staff perceived that they individually needed additional training, Table 5.18 shows that around 30 percent of crew chiefs and crew members perceived that their "weatherization team" needed additional training on mold and mildew, asbestos, vermiculite, HVAC, Base Loads, and hot water heating.

Table 5.18. Ability of Crew to Meet Weatherization Requirements

\begin{tabular}{|c|c|c|}
\hline \multirow[t]{2}{*}{ Area } & \multicolumn{2}{|c|}{ Ratings of 4 or 5} \\
\hline & Chief & Member \\
\hline Number of Respondents & 268 & 264 \\
\hline Mold and mildew & $32 \%$ & $32 \%$ \\
\hline Asbestos & $34 \%$ & $32 \%$ \\
\hline Vermiculite & $35 \%$ & $30 \%$ \\
\hline Space heating, ventilation and air conditioning & $33 \%$ & $27 \%$ \\
\hline Base loads (lighting, refrigerators) & $31 \%$ & $26 \%$ \\
\hline Hot water heating & $34 \%$ & $25 \%$ \\
\hline Lead & $15 \%$ & $19 \%$ \\
\hline General crew safety & $10 \%$ & $15 \%$ \\
\hline Door and window installation/repair & $6 \%$ & $14 \%$ \\
\hline Insulation & $6 \%$ & $8 \%$ \\
\hline Infiltration/air sealing & $6 \%$ & $8 \%$ \\
\hline
\end{tabular}




\section{WEATHERIZATION SERVICE DELIVERY}

Weatherization staff are responsible for delivery of services to clients. Grantee and subgrantee program managers furnished information on service delivery in other research conducted for the PY 2008 program evaluation. In the Weatherization Staff Survey, auditors, crew chiefs, and crew members furnished their feedback on program service delivery from the perspective of working directly with clients and housing units. This section of the report provides findings from the Baseline Survey on audits and measure selection, client deferrals, adaptive procedures, team communications, work quality, and health and safety issues.

Audit and Measure Selection Procedures - The survey asked auditors to give their perceptions of the relative merits of priority lists and computerized audits, and to discuss measure selection procedures.

- Client Deferrals - The survey asked auditors to discuss the policies they follow and their experiences with client deferrals.

- Adaptive Procedures - The survey asked crew chiefs to discuss how often and in what ways they have to adapt the measure installation to conditions found in the home that may not have been fully understood by the auditor.

- Perceptions of Work Quality - The survey asked crew chiefs and crew members to assess the quality of measure installation.

The statistics in this section help to demonstrate that there is some variation in service delivery procedures across the program. In some cases, those differences are an outcome of differences in opinions on the best approach to weatherization (e.g., use of computerized audits vs. priority lists). But, in other cases, the differences are likely to be differences in the clients and housing stock served by the program (e.g., differences in deferral rates). Most illuminating, perhaps, is the fact that there is a significant overlap between the items on which crew chiefs and crew members perceive that they need additional training and the items on which they perceive that the quality of their work is not as high as they might want it to be.

\subsection{MEASURE SELECTION PROCEDURES}

DOE guidelines allow subgrantees to use either approved audits or approved priority lists for selecting the weatherization measures to be installed in each home. Some auditors perceive that using a computerized audit helps them to make better decisions about what measures to install in a home, while others perceive that priority lists of cost-effective measures are a more efficient way to select measures for a home. Tables 6.1 through 6.5 show that there is a considerable amount of variation in auditor perceptions of these different procedures.

Some grantees have approval from DOE to use both computerized audits and priority lists, while others require a computerized audit to be used on every home. In those states where both procedures are approved, the priority list is sometimes the default procedure. Table 6.1 shows that 53 percent of auditors reported that they use both types of procedures, 19 percent reported that they use only computerized audits, and 27 percent report that they use only priority lists. 
Table 6.1. Measure Selection Procedure Used (Auditors)

\begin{tabular}{|l|c|}
\hline \multicolumn{2}{||c|}{$\begin{array}{c}\text { Does your agency use priority lists or computer } \\
\text { audits or both? }\end{array}$} \\
\hline \hline & Auditor \\
\hline \hline Number of Respondents & 350 \\
\hline \hline Both & $53 \%$ \\
\hline Priority Lists & $27 \%$ \\
\hline Computer Audits & $19 \%$ \\
\hline \hline No Answer & $1 \%$ \\
\hline \hline Total & $100 \%$ \\
\hline \hline
\end{tabular}

Auditors were asked to write in answers about the advantages and disadvantages of each procedure. Tables 6.2 through 6.5 furnish statistics on auditor perceptions of audit procedures.

- Table 6.2 shows that 46 percent of auditors listed advantages of computerized audits with the number one advantage being that they deliver "accurate and comprehensive results." Nine percent of auditors also reported that they are "faster and easier."

- Table 6.3 shows that nine percent of auditors reported that the major disadvantage of computerized audits is that they are "time-consuming." Another reported disadvantage is that there are problems with the accuracy of the selected measures (7\%).

- Table 6.4 shows that 37 percent of auditors listed advantages of priority lists, with the most common response being that they are faster and easier (17\%).

- Table 6.5 shows that 24 percent of auditors listed disadvantages of priority lists with the top three reasons all relating to poor measure selection.

It is difficult to assess the responses to these questions because less than one-half of auditors chose to furnish an answer to these questions and because it would be hard for those auditors who only use one procedure to fairly judge the other procedure. However, it is important to see that there is considerable disagreement among auditors about measure selection procedures.

- Quality - One might expect that auditors would consider computerized audits to be higher quality. But, some auditors list quality problems with computerized audits and some ways in which priority lists can increase quality.

- Computerized Audits - Some auditors consider that computerized audits give "accurate and comprehensive results" while others note that computerized audits "are only as good as input data" and "do not utilize auditor's common sense."

- Priority Lists - Some auditors perceive that priority lists "make sure that most important measures are done" and "allows the auditor to tailor measures to home," while others note that they are "too general" or "miss needed measures." 
- Timeliness - While one might expect that auditors would consider priority lists to be quicker and easier, some report that that computerized audits are faster and that computerized audits improve record-keeping.

There is no consensus among auditors working the WAP program with respect to which measure selection procedures are most effective.

Table 6.2. Advantages of Audits (Auditors)

\begin{tabular}{|c|c|}
\hline \multicolumn{2}{|l|}{$\begin{array}{l}\text { What do you see as the advantages of computer audits? } \\
\text { [Response may have more than one code] }\end{array}$} \\
\hline & Auditor \\
\hline Number of Respondents & 350 \\
\hline Accurate and Comprehensive Results & $15 \%$ \\
\hline Calculates Savings and Cost Effectiveness & $10 \%$ \\
\hline Faster and Easier & $9 \%$ \\
\hline Fair and Objective Results & $7 \%$ \\
\hline Recordkeeping (Data Organization/Better Supervision And Reporting) & $7 \%$ \\
\hline Other & $2 \%$ \\
\hline Don’t Know & $3 \%$ \\
\hline No Answer Given & $54 \%$ \\
\hline
\end{tabular}

Table 6.3. Disadvantages of Audits (Auditors)

\begin{tabular}{|c|c|}
\hline \multicolumn{2}{|c|}{$\begin{array}{c}\text { What do you see as the disadvantages of computer audits? } \\
\text { [Response may have more than one code] }\end{array}$} \\
\hline & Auditor \\
\hline Number of Respondents & 350 \\
\hline Time-Consuming & $9 \%$ \\
\hline Can Be Inaccurate/Only As Good As Input Data & $7 \%$ \\
\hline $\begin{array}{l}\text { Computer and Software Issues (Hard to Use/Glitches/Poorly } \\
\text { Designed/Outdated/Input Errors) }\end{array}$ & $6 \%$ \\
\hline $\begin{array}{l}\text { Does Not Utilize Auditor's Common Sense/Past Experience/Visual } \\
\text { Cues of Damage }\end{array}$ & $6 \%$ \\
\hline Lack of Flexibility/Missed Measures & $5 \%$ \\
\hline Other & $3 \%$ \\
\hline Don’t Know & $1 \%$ \\
\hline No Answer Given & $69 \%$ \\
\hline
\end{tabular}


Table 6.4. Advantages of Priority Lists (Auditors)

\begin{tabular}{|l|c|}
\hline \multicolumn{2}{|c|}{$\begin{array}{c}\text { What do you see as the advantages of priority lists? } \\
\text { [Response may have more than one code] }\end{array}$} \\
\hline \hline \multicolumn{2}{|c||}{} \\
\hline \hline Number of Respondents & 350 \\
\hline \hline Faster and Easier & $17 \%$ \\
\hline Makes Sure Most Important Measures are Done & $6 \%$ \\
\hline Allows Auditor Flexibility/Ability to Tailor Measures to Home & $5 \%$ \\
\hline Treats Everyone Fairly/The Same & $3 \%$ \\
\hline Other & $6 \%$ \\
\hline Don't Know & $2 \%$ \\
\hline No Answer Given & $63 \%$ \\
\hline
\end{tabular}

Table 6.5. Disadvantages of Priority Lists (Auditors)

\begin{tabular}{|l|c|}
\hline \multicolumn{2}{|c|}{$\begin{array}{c}\text { What do you see as the disadvantages of priority lists? } \\
\text { [Response may have more than one code] }\end{array}$} \\
\hline \multicolumn{2}{|c|}{} \\
\hline Number of Respondents & 350 \\
\hline Too General - 'One Size Fits All' & $8 \%$ \\
\hline Miss Needed Measures or Add Unnecessary Measures & $7 \%$ \\
\hline Can Be Inaccurate and Subjective/Requires Auditor Experience & $6 \%$ \\
\hline Other & $3 \%$ \\
\hline Don't Know & $1 \%$ \\
\hline No Answer Given & $76 \%$ \\
\hline
\end{tabular}

Auditors also were asked to discuss what measures, if any, they were reluctant to specify because of the difficulty of installing the measure. Table 6.6 shows that only 20 percent of auditors indicated that they were reluctant to specify certain measures.

Table 6.6. Reluctant to Include Measures on Job Orders (Auditors)

\begin{tabular}{|c|c|}
\hline \multicolumn{2}{|c|}{$\begin{array}{l}\text { Are there any measures that you are reluctant to include in } \\
\text { job orders because crews have difficulty installing them? }\end{array}$} \\
\hline & Auditor \\
\hline Number of Respondents & 350 \\
\hline Yes & $20 \%$ \\
\hline No & $80 \%$ \\
\hline Total & $100 \%$ \\
\hline
\end{tabular}


Table 6.7 shows that the measures identified by auditors as difficult to install include exhaust fans, mobile home measures, and work in crawl spaces and mobile home "bellies."

Table 6.7. Measures Difficult to Install (Auditors)

\begin{tabular}{||l||c|c||}
\hline \multicolumn{1}{|c|}{$\begin{array}{c}\text { Are there any measures that you are reluctant to include in job orders because crews have } \\
\text { difficulty installing them? If yes, what measures? }\end{array}$} \\
\hline \hline & $\begin{array}{c}\text { Auditors Reluctant to } \\
\text { Include Measures Due to } \\
\text { Installation Difficulty }\end{array}$ & $\begin{array}{c}\text { All } \\
\text { Respondents } \\
\text { (Auditor) }\end{array}$ \\
\hline Number of Respondents & 71 & 350 \\
\hline Venting Exhaust Fan & $15 \%$ & $3 \%$ \\
\hline Insulation - Other/Unspecified & $13 \%$ & $3 \%$ \\
\hline Mobile Home Insulation (Belly, Sidewall, Attic) & $10 \%$ & $2 \%$ \\
\hline Work in Crawlspace or Mobile Home Belly & $10 \%$ & $2 \%$ \\
\hline Foundation Insulation & $8 \%$ & $2 \%$ \\
\hline Spray Foam Insulation & $7 \%$ & $1 \%$ \\
\hline Electrical Work & $7 \%$ & $1 \%$ \\
\hline Other & $38 \%$ & $8 \%$ \\
\hline Not Applicable & $0 \%$ & $80 \%$ \\
\hline \hline No Answer & $3 \%$ & $1 \%$ \\
\hline
\end{tabular}

Finally, auditors were asked to comment on the amount of influence that clients have on the final set of measures installed in their homes. Table 6.8 shows that 58 percent of auditors indicate that clients have little or no influence on measures, while in 10 percent of homes, clients have a "great deal" of influence. However, since subgrantees are expected to install measures in homes according to standard procedures for their state, it is somewhat concerning that 10 percent of auditors report this amount of influence by clients on installed measures.

Table 6.8. Client Influence on Measures (Auditors)

\begin{tabular}{|l|c||}
\hline $\begin{array}{c}\text { How much influence does the client usually have on the final set } \\
\text { of measures included in the weatherization job order? }\end{array}$ \\
\hline \hline & Auditor \\
\hline \hline Number of Respondents & 350 \\
\hline \hline Total Influence & $1 \%$ \\
\hline A Great Deal of Influence & $9 \%$ \\
\hline Some Influence & $32 \%$ \\
\hline Little Influence & $39 \%$ \\
\hline No Influence & $19 \%$ \\
\hline \hline No Answer & $1 \%$ \\
\hline \hline Total & $100 \%$ \\
\hline
\end{tabular}




\subsection{CLIENT DEFERRALS}

Sometimes auditors will need to defer treatment of a client's home. That most often occurs if there are conditions in the home that cannot be remediated under the program guidelines and/or would exacerbate unsafe conditions in the home. Auditors were asked to report on deferral guidelines, the share of homes affected by deferrals, and the primary reasons for deferrals. Table 6.9 shows that 81 percent of auditors indicate that their state and/or weatherization agency has a written deferral policy. However, 9 percent of auditors report that their state doesn't have a written policy and 9 percent report that they don't know if there is a written policy.

Table 6.9. Standard Deferral Policy (Auditors)

\begin{tabular}{|l|c|}
\hline $\begin{array}{c}\text { Does your state or weatherization agency have a standard walk-away } \\
\text { or deferral policy written in a program manual or field guide? }\end{array}$ \\
\hline \hline & Auditor \\
\hline \hline Number of Respondents & 350 \\
\hline \hline Yes & $81 \%$ \\
\hline No & $9 \%$ \\
\hline Don't Know & $9 \%$ \\
\hline \hline No Answer & $<1 \%$ \\
\hline \hline Total & $100 \%$ \\
\hline
\end{tabular}

Table 6.10 shows that many auditors need to defer only a small percentage of homes; 10 percent say that they "never" defer homes and 79 percent defer up to 10 percent of homes. However, 5 percent of auditors report that they recommend deferring homes more than 20 percent of the time.

Table 6.10. Percent of Homes Deferred (Auditors)

\begin{tabular}{|l|c||}
\hline \multicolumn{2}{|c|}{$\begin{array}{c}\text { How often do you recommend walking away from homes or } \\
\text { deferring services? }\end{array}$} \\
\hline \hline & Auditor \\
\hline \hline Number of Respondents & 350 \\
\hline \hline Never & $10 \%$ \\
\hline $1-5 \%$ of Time & $68 \%$ \\
\hline $6-10 \%$ of Time & $11 \%$ \\
\hline $11-20 \%$ of Time & $5 \%$ \\
\hline $21 \%$ or More of Time & $5 \%$ \\
\hline No Answer & $1 \%$ \\
\hline Total & $100 \%$ \\
\hline
\end{tabular}

Table 6.11 shows that there are a lot of different reasons for deferring a home. One common set of deferral reasons is that weatherization would likely exacerbate unsafe conditions in the home, such as excessive mold or moisture, unsanitary conditions, or the presence of friable asbestos. A second set of deferral reasons relates to the high cost of repairing certain conditions in the home such as electrical, plumbing, or mechanical equipment. In some cases the auditor also reports that client issues such as illegal activities in the home cause a deferral. However, those reasons are reported by only a small share of auditors. 
Table 6.11. Reasons for Deferral - Frequently or Very Frequently (Auditors)

\begin{tabular}{|l||l||}
\hline \hline How frequently do you walk away or defer services for the reasons listed below? \\
\hline \hline Auditor \\
\hline \hline Number of Respondents: 350 & Very Frequently or \\
\hline \hline Reasons for Walk-away or Deferred Services & $33 \%$ \\
\hline \hline Excessive Mold/Moisture & $30 \%$ \\
\hline Unsanitary Conditions & $28 \%$ \\
\hline Excessive Repair that is Cost-Prohibitive & $27 \%$ \\
\hline Structurally Unsound or Dilapidated Unit & $19 \%$ \\
\hline Unsafe Electrical, Plumbing or Mechanical Equipment & $14 \%$ \\
\hline Infestation of Rodents, Insects, or Other Vermin & $12 \%$ \\
\hline Friable Asbestos & $7 \%$ \\
\hline Client Health & $7 \%$ \\
\hline Other Unsafe IAQ Issues & $7 \%$ \\
\hline Client Uncooperative or Threatening Behavior & $6 \%$ \\
\hline Illegal Activities or Drug Abuse in the Home & $6 \%$ \\
\hline Excessive CO Levels & $5 \%$ \\
\hline Unsecured Pets & $4 \%$ \\
\hline Extent/Condition of Lead-Based Paint & $3 \%$ \\
\hline Improperly Stored Hazardous Materials & $0 \%$ \\
\hline Other Reason(s) & \\
\hline
\end{tabular}

Table 6.12 shows that, from the auditors' perspective, there is no program-wide standard procedure for communicating deferrals or for referring clients. About 66 percent of auditors report that the client is sent a written communication in letter form, and 80 percent report that the client either gets that letter or is given a standard deferral form. However, that means that 20 percent of clients who are deferred are only told about the deferral verbally. Table 6.13 shows that 66 percent of auditors' report that they know that clients are referred to other community service providers. Almost one in four auditors doesn't know whether the clients are referred to other agencies. 
Table 6.12. Communication with Client about Deferral (Auditors)

How do you communicate to the clients when you conclude that the home will not be weatherized? ${ }^{l}$ (Select all that apply)

\begin{tabular}{|l|c|}
\hline \multicolumn{1}{|c|}{} & Auditor \\
\hline \hline Number of Respondents & 314 \\
\hline \hline Verbal Communication in Person after the Inspection & $76 \%$ \\
\hline Written Communication in Letter Form & $66 \%$ \\
\hline Standard Deferral Form & $39 \%$ \\
\hline Letter and/or Deferral Form & $80 \%$ \\
\hline Verbal Communication after the Inspection by Phone & $24 \%$ \\
\hline A Difference Agency Person Communicates the Decision to the Client & $18 \%$ \\
\hline Other Method & $1 \%$ \\
\hline
\end{tabular}

${ }^{\mathrm{I}}$ This question was only asked to auditors who recommend walk-aways or deferrals at least $1 \%$ of the time.

Table 6.13. Referral of Households to Other Providers (Auditors)

\begin{tabular}{||c||}
\hline \multicolumn{2}{||c||}{$\begin{array}{c}\text { Does your agency refer walk-away households to other } \\
\text { community service providers? }\end{array}$} \\
\hline \hline
\end{tabular}

\subsection{ADAPTIVE PROCEDURES}

Auditors conduct audits and specify measures. However, the weatherization crews install measures. Crew chiefs were asked questions about how often they need to adapt the installed measures to conditions they find in the home and were asked about how they communicate with auditors about those changes.

- Tables 6.14 through 6.16 furnish information on the extent to which crew chiefs depart from the work scope furnished by auditors and how often homes present special challenges that may not have been anticipated by the auditor.

- Table 6.14 shows that some crew chiefs (16\%) never install measures not included in the original job order, the majority (55\%) installed unspecified measures in up to 25 percent of jobs, and some $(27 \%)$ installed unspecified measures in more than 25 percent of homes.

- Table 6.15 shows that crew chiefs rarely fail to install specified measures. Almost all (86\%) say that they would fail to install a specified measure in less than 10 percent of jobs. 
- Table 6.16 shows that most crew chiefs $(72 \%)$ feel that they need to find solutions that go beyond standard best practices in at least some homes that they serve. About 27 percent of crew chiefs report that they find this situation in 26 percent or more of the homes that they serve.

Given the complexity of the weatherization process, it seems reasonable that sometimes crew chiefs will need to use their judgment on how best to complete a weatherization job. However, Table 6.17 shows that 63 percent of crew chiefs report that they "seldom" or "never" seek clarification from auditors.

Table 6.14. Share of Homes Where Unspecified Measures Installed (Crew Chiefs)

\begin{tabular}{|c|c|}
\hline \multicolumn{2}{|c|}{$\begin{array}{c}\text { In what percentage of weatherization jobs does your crew } \\
\text { install measures not originally contained in the job } \\
\text { orders? }\end{array}$} \\
\hline & Crew Chief \\
\hline Number of Respondents & 268 \\
\hline $0 \%$ & $16 \%$ \\
\hline $1-25 \%$ & $55 \%$ \\
\hline $26-50 \%$ & $13 \%$ \\
\hline $51-75 \%$ & $8 \%$ \\
\hline $76-100 \%$ & $6 \%$ \\
\hline No Answer & $1 \%$ \\
\hline Total & $100 \%$ \\
\hline
\end{tabular}

Table 6.15. PY 2011 Weatherization Staff SurveyShare of Homes Where Specified Measures Not Installed (Crew Chiefs)

\begin{tabular}{|l|c|}
\hline $\begin{array}{c}\text { In what percentage of weatherization jobs does your crew } \\
\text { install measures not originally contained in the job } \\
\text { orders? }\end{array}$ \\
\hline \hline & Crew Chiefs \\
\hline \hline Number of Respondents & 268 \\
\hline \hline $0 \%$ & $41 \%$ \\
\hline $1-5 \%$ & $35 \%$ \\
\hline $6-10 \%$ & $10 \%$ \\
\hline $11-100 \%$ & $11 \%$ \\
\hline \hline No Answer & $2 \%$ \\
\hline \hline Total & $100 \%$ \\
\hline
\end{tabular}


Table 6.16. Share of Homes Requiring Solutions Beyond Standard Practices (Crew Chiefs)

\begin{tabular}{|l|c|}
\hline \multicolumn{2}{|c|}{$\begin{array}{c}\text { In what share of homes do you encounter situations } \\
\text { where installation of measures requires solutions that go } \\
\text { beyond standard best practices? }\end{array}$} \\
\hline & Crew Chiefs \\
\hline \hline Number of Respondents & 268 \\
\hline \hline $0 \%$ & $27 \%$ \\
\hline $1-25 \%$ & $45 \%$ \\
\hline $26-50 \%$ & $17 \%$ \\
\hline $51-75 \%$ & $7 \%$ \\
\hline $76-100 \%$ & $3 \%$ \\
\hline No Answer & $1 \%$ \\
\hline Total & $100 \%$ \\
\hline
\end{tabular}

Table 6.17. Clarification or Interpretation from Auditors (Crew Chiefs)

\begin{tabular}{||l|c||}
\hline \multicolumn{2}{|c|}{$\begin{array}{c}\text { How frequently do you see clarification or interpretation } \\
\text { of instructions from auditors? }\end{array}$} \\
\hline \hline & Crew Chief \\
\hline \hline Number of Respondents & 268 \\
\hline \hline All the time & $6 \%$ \\
\hline Very often & $9 \%$ \\
\hline Often & $21 \%$ \\
\hline Seldom & $56 \%$ \\
\hline Never & $7 \%$ \\
\hline No Answer & $1 \%$ \\
\hline Total & $100 \%$ \\
\hline
\end{tabular}

\subsection{PERCEPTIONS OF WORK QUALITY}

Both crew chiefs and crew members were asked to furnish an assessment of the quality of their crew in completing weatherization tasks. Table 6.18 shows that, in general, crew chief and crew member ratings were consistent. They gave the highest marks (i.e., rated performance as "excellent" or "very good") for the most common weatherization measures and health and safety practices. They were less likely to give high grades for those items that are performed less often.

- Weatherization Measures

- High Ratings - Both crew chiefs and crew members gave high ratings for the quality of infiltration/air sealing, insulation, and door/window installation/repair.

- Lower Ratings - They were less likely to give high ratings for baseload measures, HVAC, and hot water measures. 
- Health and Safety

- High Ratings - Both crew chiefs and crew members gave high ratings for general crew safety and lead.

- Lower Ratings - They were less likely to give high ratings for mold and mildew, asbestos, and vermiculite.

It is interesting to note that many of the measures and practices on which crew chiefs and crew members gave lower ratings were issues on which they had previously noted that additional training was needed.

Table 6.18. Crew Work Quality - Percent with Ratings of "Excellent" or "Very Good"

\begin{tabular}{|c|c|c|}
\hline Area & Ratings & or 5 \\
\hline & $\begin{array}{c}\text { Crew Chief - Rating of "Excellent" } \\
\text { or "Very Good" }\end{array}$ & $\begin{array}{l}\text { Crew Member - Rating of } \\
\text { "Excellent" or "Very Good" }\end{array}$ \\
\hline Number of Respondents & 268 & 264 \\
\hline Infiltration/air sealing & $93 \%$ & $87 \%$ \\
\hline Insulation & $92 \%$ & $91 \%$ \\
\hline Door/window installation/repair & $89 \%$ & $85 \%$ \\
\hline Baseloads & $68 \%$ & $70 \%$ \\
\hline HVAC & $66 \%$ & $69 \%$ \\
\hline Hot water heating & $64 \%$ & $65 \%$ \\
\hline General crew safety & $82 \%$ & $80 \%$ \\
\hline Lead & $80 \%$ & $75 \%$ \\
\hline Mold and mildew & $59 \%$ & $59 \%$ \\
\hline Asbestos & $60 \%$ & $61 \%$ \\
\hline Vermiculite & $53 \%$ & $56 \%$ \\
\hline
\end{tabular}

In general, crew chiefs perceived that their crews did a very good job on their weatherization tasks. The survey asked crew chiefs to identify what, if any, factors were a "hindrance to carrying out their crew chief responsibilities." Table 6.19 shows that there was no one factor that stood out to crew chiefs as presenting a major barrier to getting the job done effectively.

Table 6.19. Hindrances to Crew Chief Responsibilities - Ratings of "Extremely Great" or "Very Great"

\begin{tabular}{||l||c|}
\hline \multicolumn{2}{|c|}{ How much of a hindrance are the following to your ability to carry out your crew chief responsibilities? } \\
\hline \hline \multicolumn{1}{||c|}{} & "Extremely Great" or "Very Great? \\
\hline \hline Number of Respondents & 268 \\
\hline \hline Lack of training of crew members & $11 \%$ \\
\hline Getting crews to finish jobs on time and within budget & $11 \%$ \\
\hline Interpersonal problems amongst crew members & $7 \%$ \\
\hline Language barriers with crew & $7 \%$ \\
\hline \hline Crew tardiness & $7 \%$ \\
\hline
\end{tabular}





\section{WORKING WITH CLIENTS}

Weatherization staff work directly with clients on a daily basis. In all programs, the staff are responsible for working with clients to inform them of what is being done to their home, to respond to their concerns about the weatherization work, and to be responsive to other client issues. In some programs, they are also responsible for furnishing energy education to the client and their family. This section of the report documents the extent to which certain barriers affect service delivery and the ways in which weatherization staff attempt to overcome any barriers that they encounter.

- Language Barriers - The survey asked staff how often they encountered language barriers and what they did to address them.

- Other Client Issues - The survey asked staff about the other kinds of issues they encounter with clients and how they dealt with those issues.

- Staff Safety - The survey asked staff to report on those situations where they felt unsafe doing audits or delivering weatherization services.

- Informal Energy Education with Clients, Families, and Neighbors - The survey asked staff to report on their experiences with information education of clients, their families, and their neighbors.

The statistics in this section furnish some useful insights with respect to the interactions of staff and clients. They show that language barriers are important, but are found in a relatively small share of the population. Staff do report that they face other important challenges completing their jobs, including some clients who are difficult to work with and some homes that have significant problems that staff feel put them somewhat at risk. However, the statistics also show that there is a significant amount of positive interactions between staff and clients that result in some important energy education for clients.

\subsection{LANGUAGE BARRIERS}

The statistics presented in Section 3 of the report showed that English was the native language for over 90 percent of weatherization staff, but that a significant number of staff reported that they can speak Spanish and other languages at a conversational level. The statistics in this section show how often staff are successfully able to communicate despite those potential barriers.

Table 7.1 shows that, when asked about language barriers, many auditors (37\%) and crew chiefs (50\%) indicated that they did not encounter any language barriers, either because the client spoke English or because they spoke the client's language. However, 23 percent of auditors and 14 percent of crew chiefs did indicate that a language barrier was a problem in over 5 percent of their jobs. (Note: The estimated median percentage of language barriers is about $2 \%$ and the mean percentage of language barriers is about $4 \%$. That means that staff encounter language barriers for about 1 in 25 clients.)

Table 7.2 shows that, among those that did encounter a language barrier, some were able to use a translator (38\% for auditor / $17 \%$ for crew chief), some counted on a relative or neighbor ( $24 \%$ for auditor / $21 \%$ for crew chief), and some could ask other agency staff for assistance (23\% for auditor / 26\% for crew chief). However, in over 20 percent of situations, it appears that the auditor and/or crew chief just "made do" and communicated as effectively as they could without the support of a translator. (Note: If staff encounter language barriers with 1 in 25 clients and in about one in five of those the staff "make do," that means that this situation affects less than 1 in 100 clients.) 
Table 7.1. Language Barriers with Clients

\begin{tabular}{|c|c|c|}
\hline \multicolumn{3}{|c|}{ In what percentage of homes do you encounter language barriers with clients? } \\
\hline & Auditor & Chief \\
\hline Number of Respondents & 350 & 268 \\
\hline $0 \%$ & $37 \%$ & $50 \%$ \\
\hline $1-5 \%$ & $40 \%$ & $32 \%$ \\
\hline $6-10 \%$ & $10 \%$ & $6 \%$ \\
\hline More than $10 \%$ & $13 \%$ & $8 \%$ \\
\hline No Answer & $1 \%$ & $3 \%$ \\
\hline Total & $100 \%$ & $100 \%$ \\
\hline
\end{tabular}

Table 7.2. Response to Language Barriers with Clients

\begin{tabular}{|c|c|c|}
\hline \multicolumn{3}{|c|}{ What do you do when you encounter a language barrier with clients? } \\
\hline & Auditor & Chief \\
\hline Number of Respondents & 222 & 129 \\
\hline Used Translator (Unspecified) & $38 \%$ & $17 \%$ \\
\hline Use Relative/Neighbor to Translate & $24 \%$ & $21 \%$ \\
\hline Use Other Agency Staff to Translate & $23 \%$ & $26 \%$ \\
\hline Try My Best to Communicate & $21 \%$ & $26 \%$ \\
\hline Other & $10 \%$ & $9 \%$ \\
\hline No Answer & $5 \%$ & $9 \%$ \\
\hline
\end{tabular}

\subsection{OTHER CLIENT ISSUES}

Weatherization staff report that sometimes clients make it more difficult for them to do their jobs. Auditors were asked to assess how often client interactions impede their ability to do their jobs and crew chiefs were asked to assess how often difficult clients affected their ability to complete the delivery of weatherization services. In most cases, only a small percentage of clients were perceived to present a barrier to auditors and weatherization crews.

Table 7.3 shows that about 27 percent of auditors reported that more than 5 percent of clients (i.e., more than one in twenty) impeded their ability to do their jobs. Table 7.4 shows that, in most cases, the auditor was able to work through the situation. However, about 8 percent of auditors reported that they had to walk away from the job or threaten to walk away from the job to resolve the situation. This question and the response does help to illustrate the potential tension between the auditor's job to assess the home and the auditor's competing responsibility to explain to the client what weatherization measures are needed in his or her home. 
Table 7.3. Jobs Impeded by Client Interaction

\begin{tabular}{|l|c|}
\hline \multicolumn{2}{|c|}{$\begin{array}{c}\text { In what percentage of homes does client interaction impede your ability to do } \\
\text { your job? }\end{array}$} \\
\hline \hline & Auditor \\
\hline \hline Number of Respondents & 350 \\
\hline \hline $0 \%$ & $29 \%$ \\
\hline $1-5 \%$ & $44 \%$ \\
\hline $6-10 \%$ & $17 \%$ \\
\hline More than $10 \%$ & $10 \%$ \\
\hline No Answer & $1 \%$ \\
\hline \hline Total & $100 \%$ \\
\hline
\end{tabular}

Table 7.4. Response When Jobs Impeded by Client Interaction

\begin{tabular}{|c|c|c|}
\hline \multicolumn{3}{|c|}{ What do you do when client interaction impedes your ability to do your job? } \\
\hline & $\begin{array}{l}\text { Auditor Who Reported } \\
\text { Jobs Impeded by Clients }\end{array}$ & All Respondents \\
\hline N Number of Respondents & 248 & 350 \\
\hline Explain What is Being Done and Why & $27 \%$ & $19 \%$ \\
\hline Explain Time Constraints to Client & $18 \%$ & $13 \%$ \\
\hline Work Through It & $17 \%$ & $12 \%$ \\
\hline Walk Away/Threaten to Walk Away & $12 \%$ & $8 \%$ \\
\hline Ask Client to Save Questions for End of Audit & $7 \%$ & $5 \%$ \\
\hline Attempt to Distract Client & $5 \%$ & $3 \%$ \\
\hline Other & $19 \%$ & $14 \%$ \\
\hline No Answer or Not Applicable & $3 \%$ & $31 \%$ \\
\hline
\end{tabular}

Table 7.5 shows that about 25 percent of crew chiefs reported that 6 to 10 percent of clients were difficult and that 18 percent of crew chiefs reported that more than 10 percent of their clients were difficult. (Note: The median percentage was about $4 \%$ and the mean percentage was about $8 \%$.) Table 7.6 shows that, in most cases, the crew chief was able to work through the situation by communicating clearly with the client, working to make the client more satisfied, and being polite and respectful. However, about 27 percent of crew chiefs reported that they found that they needed to call their supervisor or refer the client to the agency.

Table 7.5. Difficult Clients

\begin{tabular}{|l|c|}
\hline \multicolumn{2}{|c|}{ In what percentage of homes do encounter difficult clients? } \\
\hline \hline \multicolumn{2}{|c|}{ Crew Chief } \\
\hline \hline Number of Respondents & 268 \\
\hline \hline $0 \%$ & $9 \%$ \\
\hline $1-5 \%$ & $47 \%$ \\
\hline $6-10 \%$ & $25 \%$ \\
\hline More than $10 \%$ & $18 \%$ \\
\hline \hline No Answer & $1 \%$ \\
\hline \hline Total & $100 \%$ \\
\hline
\end{tabular}


Table 7.6. Response to Difficult Clients

\begin{tabular}{|l||c||c|}
\hline \multicolumn{2}{|c|}{ What do you do when you encounter a difficult client? } \\
\hline \hline & $\begin{array}{c}\text { Crew Chief Who } \\
\text { Reported Jobs Impeded } \\
\text { by Clients }\end{array}$ & All Respondents \\
\hline \hline Number of Respondents & 244 & 268 \\
\hline \hline Explain What is Being Done and Why & $29 \%$ & $26 \%$ \\
\hline Call Supervisor / Refer Client to Agency & $27 \%$ & $4 \%$ \\
\hline Work to Make the Client Satisfied & $22 \%$ & $20 \%$ \\
\hline Be Polite and Respectful & $12 \%$ & $11 \%$ \\
\hline Work Through It & $7 \%$ & $5 \%$ \\
\hline Other & $19 \%$ & $14 \%$ \\
\hline No Answer or Not Applicable & $6 \%$ & $15 \%$ \\
\hline
\end{tabular}

\subsection{STAFF SAFETY}

The safety of weatherization staff is one important issue for the program. Weatherization staff are sometimes asked to work with clients who may have psychological problems, in homes that have health and safety issues, and in neighborhoods that may be unsafe. The survey asked weatherization staff to estimate how often they encounter such problems, and to identify the problems that are most common in their work.

Table 7.7 shows the percentage of homes in which weatherization staff report that they "feel unsafe." About one-fourth of auditors and crew chiefs say that they never feel unsafe, and only 8 percent of auditors and 16 percent of crew chiefs report that they feel unsafe in more than 10 percent of homes. Crew members are somewhat more concerned about their safety; 35 percent feel unsafe on more than 10 percent of their weatherization jobs. (Note: The median rate is 2 percent for auditors, 3 percent for crew chiefs, and 9 percent for crew members. The mean rate is 4 percent for auditors, 5 percent for crew chiefs, and 9 percent for crew members.)

Table 7.7. Percentage of Homes That Feel Unsafe

\begin{tabular}{|c|c|c|c|}
\hline \multicolumn{4}{|c|}{ In what percent of homes do you feel unsafe entering to do audits/weatherization jobs? } \\
\hline & Auditor & Chief & Member \\
\hline Number of Respondents & 350 & 268 & 264 \\
\hline $0 \%$ & $22 \%$ & $24 \%$ & $14 \%$ \\
\hline $1-5 \%$ & $56 \%$ & $45 \%$ & $29 \%$ \\
\hline $6-10 \%$ & $13 \%$ & $15 \%$ & $20 \%$ \\
\hline More than $10 \%$ & $8 \%$ & $16 \%$ & $35 \%$ \\
\hline No Answer & $1 \%$ & $0 \%$ & $2 \%$ \\
\hline Total & $100 \%$ & $100 \%$ & $100 \%$ \\
\hline
\end{tabular}

Table 7.8 shows some of the specific conditions that make staff feel unsafe. For auditors, pets are listed at the highest rate and house conditions are also very important. For both crew chiefs and crew members, household conditions, particularly unsanitary conditions, present the most significant problem. While client and neighborhood issues are a problem for some staff, they are less of a problem than are pets and the condition of the homes that they serve. 
Table 7.8. Situations That Feel Unsafe

\begin{tabular}{||l||c||c|c||}
\hline \multicolumn{3}{|c|}{ What situations typically make you feel unsafe? (Response may have more than one code.) } \\
\hline \hline & Auditor & Chief & Member \\
\hline \hline Number of Respondents & 350 & 268 & 264 \\
\hline Pets & $33 \%$ & $19 \%$ & $21 \%$ \\
\hline House Conditions (Unsanitary) & $26 \%$ & $34 \%$ & $42 \%$ \\
\hline House Conditions (Structural/Safety) & $13 \%$ & $12 \%$ & $17 \%$ \\
\hline House Conditions (Indoor Air Quality) & $9 \%$ & $13 \%$ & $16 \%$ \\
\hline House Conditions (Infestation) & $9 \%$ & $11 \%$ & $10 \%$ \\
\hline Aggressive/Unstable Clients & $14 \%$ & $6 \%$ & $6 \%$ \\
\hline Drugs/Alcohol & $17 \%$ & $14 \%$ & $6 \%$ \\
\hline Neighborhood & $7 \%$ & $5 \%$ & $7 \%$ \\
\hline Guns/Gangs & $7 \%$ & $4 \%$ & $1 \%$ \\
\hline Other & $18 \%$ & $6 \%$ & $13 \%$ \\
\hline \hline No Answer & $1 \%$ & $4 \%$ & $5 \%$ \\
\hline
\end{tabular}

Table 7.9 shows that, while they don't always report it as a condition that makes them feel unsafe, most crew chiefs and crew members see health and safety problems in many client homes. Lead is the most common problem and is observed "frequently" or "very frequently" by about two-thirds of staff. With respect to other problems, crew members report a higher rate of problems than do crew chiefs, perhaps because they are closer to the work than are the crew chiefs, who might be supervising work at multiple sites.

Table 7.9. Frequency of Health and Safety Issues

\begin{tabular}{||l|c|c|}
\hline $\begin{array}{c}\text { How frequently does the crew encounter the health and safety issues listed below? } \\
\text { (\% reporting "frequently" or "very frequently") }\end{array}$ \\
\hline \hline & Crew Chief & Crew Member \\
\hline \hline Number of Respondents & 268 & 264 \\
\hline \hline Lead & $68 \%$ & $69 \%$ \\
\hline Mold and Mildew & $42 \%$ & $58 \%$ \\
\hline General Crew Safety Issues & $37 \%$ & $41 \%$ \\
\hline Asbestos & $35 \%$ & $42 \%$ \\
\hline Vermiculite & $27 \%$ & $42 \%$ \\
\hline \hline Total & $100 \%$ & $100 \%$ \\
\hline
\end{tabular}

\subsection{INFORMAL EDUCATION, AND OTHER INTERACTIONS}

In many programs, there is a formal education component of weatherization service delivery that is administered by staff. However, the weatherization process presents a significant number of opportunities for staff to furnish information education to the clients, as well as to other family members and neighbors.

Table 7.10 shows almost one-half of auditors and about one-fourth of crew chiefs and crew members report that "a great deal" of informal education occurs as part of their work. About 10 percent of auditors and about one-fourth of crew chiefs and crew members indicate that "little" or "no" information education occurs. Given this level of opportunity for interaction, it would seem appropriate for all types of weatherization staff to be given some exposure to effective energy education procedures. 
Table 7.10. Informal Energy Education Provided to Client

\begin{tabular}{||l||c||c|c||}
\hline \multicolumn{3}{|c|}{ How much informal education involving the clients, goes on during the usual audit/weatherization jobs? } \\
\hline \hline & Auditor & Chief & Member \\
\hline \hline Number of Respondents & 350 & 268 & 264 \\
\hline \hline A Great Deal & $46 \%$ & $24 \%$ & $29 \%$ \\
\hline Some & $44 \%$ & $53 \%$ & $46 \%$ \\
\hline Little & $9 \%$ & $19 \%$ & $17 \%$ \\
\hline None & $1 \%$ & $4 \%$ & $6 \%$ \\
\hline \hline No Answer & $0 \%$ & $0 \%$ & $2 \%$ \\
\hline \hline Total & $100 \%$ & $100 \%$ & $100 \%$ \\
\hline
\end{tabular}

Weatherization staff also have the opportunity to interact with the client's extended family and/or neighbors during service delivery. Table 7.11 shows the percentage of homes in which staff report that they "directly" interacted with the client's family and Table 7.12 shows the percentage of homes in which staff report that they "directly" interacted with the client's neighbors. Table 7.11 shows that at least onethird of auditors and crew chiefs, and almost one-half of crew members report that they "directly" interact with the client's family in more than 25 percent of jobs. However, Table 7.12 shows that most auditors, crew chiefs, and crew members report that they interact with the client's neighbors on 10 percent or fewer jobs.

Table 7.11. Interaction with Client's Extended Family

\begin{tabular}{||l|c||c|c||}
\hline \multicolumn{3}{|c|}{ In what percentage of homes do you directly interact with the client's extended family? } \\
\hline \hline & Auditor & Chief & Member \\
\hline \hline Number of Respondents & 350 & 268 & 264 \\
\hline \hline $0 \%$ & $4 \%$ & $6 \%$ & $8 \%$ \\
\hline $1-5 \%$ & $28 \%$ & $28 \%$ & $18 \%$ \\
\hline $6-10 \%$ & $16 \%$ & $19 \%$ & $14 \%$ \\
\hline $11-25 \%$ & $17 \%$ & $13 \%$ & $13 \%$ \\
\hline $26 \%$ or More & $35 \%$ & $34 \%$ & $48 \%$ \\
\hline \hline Total & $100 \%$ & $100 \%$ & $100 \%$ \\
\hline
\end{tabular}

Table 7.12. Interaction with Client's Neighbors

\begin{tabular}{||l||c||c||c||}
\hline \multicolumn{4}{|c|}{ In what percentage of homes do you directly interact with the client's neighbors? } \\
\hline \hline \multicolumn{1}{||||}{ Auditor } & Chief & Member \\
\hline \hline Number of Respondents & 350 & 268 & 264 \\
\hline \hline $0 \%$ & $31 \%$ & $23 \%$ & $16 \%$ \\
\hline $1-5 \%$ & $49 \%$ & $51 \%$ & $43 \%$ \\
\hline $11 \% \%$ or More & $12 \%$ & $13 \%$ & $16 \%$ \\
\hline \hline Total & $8 \%$ & $13 \%$ & $25 \%$ \\
\hline \hline
\end{tabular}

When compared to Table 7.10, Table 7.13 shows weatherization staff are less likely to perceive that "a great deal" of education is provided to the client's family and/or neighbors than is provided to the client. However, most staff report that at least some informal energy education is provided. 
Table 7.13. Informal Energy Education Provided to Client's Extended Family or Neighbors

How much informal education involving the client's extended family and/or neighbors goes on during the usual audit/weatherization jobs?

\begin{tabular}{|c|c|c|c|}
\hline & Auditor & Chief & Member \\
\hline Number of Respondents & 350 & 268 & 264 \\
\hline A Great Deal & $16 \%$ & $11 \%$ & $13 \%$ \\
\hline Some & $49 \%$ & $47 \%$ & $44 \%$ \\
\hline Little & $26 \%$ & $32 \%$ & $33 \%$ \\
\hline None & $9 \%$ & $9 \%$ & $11 \%$ \\
\hline Total & $100 \%$ & $100 \%$ & $100 \%$ \\
\hline
\end{tabular}





\section{AGENCY VS. CONTRACTOR CREW CHIEF FINDINGS}

Some weatherization agencies use in-house crews to deliver energy services, some use contractors, and some use both types of weatherization staff. About 20 percent of crew chiefs responding to the Baseline Survey were employed by contractors. This section of the report presents some of the areas in which it appears that agency staff and contractor staff differ.

In general, the statistics in this section show that there are some differences between agency and contractor staff. In particular, it appears that agency staff are more likely to be salaried employees who work a normal 40-hour week and receive employee benefits (e.g., health insurance and paid time off), while contractor staff are more likely to be hourly staff who work less consistently and are less likely to receive employee benefits, but who often work more hours and have a higher annual income. However, from the perspective of training, work quality, and client interactions, there appear to be far more similarities than there are differences.

\subsection{DEMOGRAPHIC CHARACTERISTICS}

Table 8.1 summarizes the difference between the crew chiefs who are employed by the local weatherization agency and those employed by contractors in terms of their demographic characteristics. The contractor staff interviewed for this survey were more likely to speak Spanish at a conversational level, were more likely to speak another language at a conversational level, and were much more likely to have taken at least some college courses. However, the only statistically significant difference in the projected population statistics is with respect to education. (Note: A difference of about 10 percentage points would be considered to be statistically significant at the 90 percent confidence level.)

Table 8.1. Crew Chief Demographics - Agency Staff Compared to Contractors

\begin{tabular}{|c|c|c|}
\hline \multicolumn{3}{|c|}{ Demographic Characteristics } \\
\hline & Agency Staff & Contractor Staff \\
\hline Number of Respondents & 211 & 57 \\
\hline Median Age & 44 years & 46 years \\
\hline$\%$ Female & $2 \%$ & $2 \%$ \\
\hline$\%$ Minority & $21 \%$ & $19 \%$ \\
\hline \% Spanish Language - Conversational & $10 \%$ & $16 \%$ \\
\hline$\%$ Other Language - Conversational & $5 \%$ & $11 \%$ \\
\hline$\%$ At Least Some College & $48 \%$ & $61 \%$ \\
\hline
\end{tabular}

\subsection{EMPLOYMENT CHARACTERISTICS}

The survey questions related to crew chief employment characteristics show both similarities and differences between agency and contractor staff. Table 8.2 shows that both types of staff consider weatherization to be their main job and that most work for just one employer. The statistics in Table 8.3 further support that characterization; over two-thirds report that they consider weatherization to be their career and the median number of years in the field is 6 years for agency staff and 7 years for contactor staff. However, Table 8.2 does show some differences in that some contractor staff work less than full time $(11 \%)$ and at the same time almost one-half of contractor staff work more than 40 hours per week (46\%). 
Table 8.2. Crew Chief Employment Status - Agency Staff Compared to Contractors

\begin{tabular}{|c|c|c|}
\hline \multicolumn{3}{|c|}{ Employment Status } \\
\hline & Agency Staff & Contractor Staff \\
\hline Number of Respondents & 211 & 57 \\
\hline \% Two or More Employers & $29 \%$ & $33 \%$ \\
\hline$\%$ Weatherization is Main Job & $95 \%$ & $93 \%$ \\
\hline$\%$ Full Time or More & $97 \%$ & $89 \%$ \\
\hline$\%$ More Than 40 Hours per Week & $20 \%$ & $46 \%$ \\
\hline
\end{tabular}

Table 8.3. Crew Chief Weatherization Career - Agency Staff Compared to Contractors

\begin{tabular}{|c|c|c|}
\hline \multicolumn{3}{|c|}{ Employment Status } \\
\hline & Agency Staff & Contractor Staff \\
\hline Number of Respondents & 211 & 57 \\
\hline$\%$ Weatherization is Career & $67 \%$ & $72 \%$ \\
\hline Median Years in Weatherization & 6 years & 7 years \\
\hline Median Years with Current Employer & 6 years & 9 years \\
\hline
\end{tabular}

One clear difference between agency staff and contractor staff is in the balance between job security and benefits (more for agency staff) and pay (higher for contactor staff). Table 8.4 shows that the median income is more than 25 percent higher for contractor staff; however, while the majority of agency staff get health benefits, only one-fourth of contactor staff get those benefits. The job satisfaction question shows high ratings for both types of staff for interactions with clients and their co-workers. However, agency staff report higher levels of satisfaction with having steady work, paid time off, and health and retirements benefits, while contractor staff report higher levels of satisfaction with pay. One statistically significant difference of note is that contractor staff report higher levels of satisfaction with job safety than do agency staff. 
Table 8.4. Crew Chief Income and Benefits - Agency Staff Compared to Contractors

\begin{tabular}{|c|c|c|}
\hline \multicolumn{3}{|c|}{ Income and Benefits } \\
\hline & Agency Staff & Contractor Staff \\
\hline Number of Respondents & 211 & 57 \\
\hline Median Income & $\$ 32,700$ & $\$ 41,700$ \\
\hline$\%$ with Health Benefits from Employer & $64 \%$ & $26 \%$ \\
\hline \multicolumn{3}{|l|}{$\%$ Satisfied with... } \\
\hline Interactions with Clients & $91 \%$ & $86 \%$ \\
\hline Co-Workers & $82 \%$ & $88 \%$ \\
\hline Steady Work & $92 \%$ & $72 \%$ \\
\hline Job Safety & $77 \%$ & $89 \%$ \\
\hline Paid Time Off Policy & $81 \%$ & $47 \%$ \\
\hline Pay & $55 \%$ & $72 \%$ \\
\hline Health Benefits & $54 \%$ & $30 \%$ \\
\hline Retirement Benefits & $54 \%$ & $32 \%$ \\
\hline
\end{tabular}

\subsection{TRAINING AND WORKFORCE DEVELOPMENT}

With respect to workforce development questions, there is a high rate of correlation between the responses for both types of staff. Table 8.5 shows that almost one-half fear that they would be unemployed if not for their current work. But, both types of staff feel that that training and experience they receive would help them to get other jobs, particularly with companies that do weatherization work for market-rate programs.

Table 8.5. Crew Chief Workforce Development - Agency Staff Compared to Contractors

\begin{tabular}{|l||c||c||}
\hline \multicolumn{2}{|c||}{ Workforce Development } \\
\hline Number of Respondents & Agency Staff & Contractor Staff \\
\hline \hline Likely to be Unemployed & 211 & 57 \\
\hline$\%$ Training Valuable in Other Jobs & $42 \%$ & $42 \%$ \\
\hline Where Training Most Valuable & $88 \%$ & $88 \%$ \\
\hline$\%$ Experience Valuable in Other Jobs & Non-Low-Income WX & Non-Low-Income WX \\
\hline Where Experience Most Valuable & $91 \%$ & $81 \%$ \\
\hline \hline
\end{tabular}

Staff training is an important component of the delivery of high-quality weatherization services. The statistics in this section of the report assess whether agency staff and contactor staff are receiving the same amount and type of training on important weatherization topics.

Table 8.6 shows that agency staff are more likely to report that they develop "A Lot" or "Most/All" of their skills through formal training (e.g., classroom training), while contractor staff are likely to report that they developed skills prior to entering the field of weatherization. However, these differences are small, and in the case of "skills developed prior to entering weatherization field," it is not a statistically 
significant difference. Moreover, Table 8.7 shows that most agency and contactor staff report that they received on-the-job training in the last five years, many report that they received on-the-job mentoring, and almost all have received some form of formal training.

Table 8.6. Crew Chief - Skills Learned - Agency Staff Compared to Contractors

\begin{tabular}{|c|c|c|}
\hline \multicolumn{3}{|c|}{ Skills Development } \\
\hline & Agency Staff & Contractor Staff \\
\hline Number of Respondents & 211 & 57 \\
\hline $\begin{array}{l}\text { \% "A Lot" or "Most/All" Prior to Entering WX } \\
\text { Field }\end{array}$ & $42 \%$ & $48 \%$ \\
\hline \% "A Lot" or "Most/All" On-the-Job Training & $72 \%$ & $72 \%$ \\
\hline \% "A Lot" or "Most/All" Formal Training & $60 \%$ & $48 \%$ \\
\hline
\end{tabular}

Table 8.7. Crew Chief - Training Approach - Agency Staff Compared to Contractors

\begin{tabular}{|c|c|c|}
\hline \multicolumn{3}{|c|}{ Training Approach } \\
\hline & Agency Staff & Contractor Staff \\
\hline Number of Respondents & 211 & 57 \\
\hline $\begin{array}{l}\text { \% "A Great Deal" or "Quite a Bit" On-the Job Training } \\
\text { Field }\end{array}$ & $63 \%$ & $62 \%$ \\
\hline \% "A Great Deal" or "Quite a Bit" On-the-Job Mentoring & $36 \%$ & $32 \%$ \\
\hline$\%$ At Least One Training Session in Last Five Years & $97 \%$ & $95 \%$ \\
\hline$\%$ At Training Center & $80 \%$ & $72 \%$ \\
\hline$\%$ At National Training Conference & $35 \%$ & $16 \%$ \\
\hline$\%$ At State Weatherization Conference & $27 \%$ & $26 \%$ \\
\hline
\end{tabular}

Table 8.8 shows the topics on which crew chiefs have been trained and Table 8.9 shows the topics on which they perceive that they need additional training. With respect to the training received, the reported rate of training is within 10 percentage points for all of the listed topics. Since a difference must be at least 10 percentage points to be statistically significant at the 90 percent confidence level, the statistics do not allow one to say that one group got more or less training on specific topics than did the other. Similarly, Table 8.9 shows that in terms of training needs, both agency staff and contactor staff have similar incidence rates for training needed. There is no statistical evidence from the survey that the staff are being trained differently on these important topics. With respect to the barriers to training, Table 8.10 does show that contractors are more likely to cite lack of training funds and lack of awareness of training as important barriers. (Note: These differences are not statistically significant.) However, the most important and statistically significant difference is that almost 20 percent of contractor staff have to pay for their own training, while only 2 percent of agency staff report that. 
Table 8.8. Crew Chief - Formal Training Topics - Agency Staff Compared to Contractors

\begin{tabular}{|c|c|c|}
\hline \multicolumn{3}{|c|}{ Training Received } \\
\hline & Agency Staff & Contractor Staff \\
\hline Number of Respondents & 211 & 57 \\
\hline \% Diagnostics Testing & $63 \%$ & $65 \%$ \\
\hline$\%$ Infiltration/Air Sealing (Single Family) & $76 \%$ & $75 \%$ \\
\hline \% Insulation (Single Family) & $74 \%$ & $67 \%$ \\
\hline$\%$ Lead & $96 \%$ & $95 \%$ \\
\hline$\%$ Mold and Mildew & $56 \%$ & $46 \%$ \\
\hline \% Indoor Air Quality & $47 \%$ & $53 \%$ \\
\hline$\%$ General Crew Safety & $74 \%$ & $67 \%$ \\
\hline
\end{tabular}

Table 8.9. Crew Chief - Training Needs - Agency Staff Compared to Contractors

\begin{tabular}{|c|c|c|}
\hline \multicolumn{3}{|c|}{ Training Needed } \\
\hline & Agency Staff & Contractor Staff \\
\hline Number of Respondents & 211 & 57 \\
\hline$\%$ That Have Outstanding Training Needs & $61 \%$ & $53 \%$ \\
\hline$\%$ Need Diagnostic Testing and Assessment & $19 \%$ & $21 \%$ \\
\hline$\%$ Need Infiltration/Air Sealing (Single Family) & $9 \%$ & $7 \%$ \\
\hline$\%$ Need Insulation (Single Family) & $6 \%$ & $4 \%$ \\
\hline$\%$ Need Lead & $7 \%$ & $7 \%$ \\
\hline$\%$ Need Mold and Mildew & $23 \%$ & $33 \%$ \\
\hline$\%$ Need Indoor Air Quality & $17 \%$ & $21 \%$ \\
\hline \% Need General Crew Safety & $12 \%$ & $9 \%$ \\
\hline
\end{tabular}

Table 8.10. Crew Chief - Reasons for Unmet Training Needs - Agency Staff Compared to Contractors

\begin{tabular}{|c|c|c|}
\hline \multicolumn{3}{|c|}{ Training Barrier } \\
\hline & Agency Staff & Contractor Staff \\
\hline Number of Respondents & 211 & 57 \\
\hline \% Not Available Right Time or Right Place & $28 \%$ & $23 \%$ \\
\hline \% Lack of Training Funds & $14 \%$ & $18 \%$ \\
\hline$\%$ Not Aware of Training & $13 \%$ & $19 \%$ \\
\hline$\%$ Have to Pay for Own Training & $2 \%$ & $19 \%$ \\
\hline
\end{tabular}

\subsection{SERVICES}

The survey asked weatherization staff about service delivery, including the consistency between job orders and installed measures, and the quality of service delivery for important weatherization measures. Table 8.11 shows crew chiefs often felt that they had to install measures that were not specified by the auditor and that they sometimes felt that they could not install specified measures. Contractor staff were more likely to deviate from job orders than were agency staff. But, the contractor staff also were more likely to report that they contacted the auditor to discuss changes. 
Table 8.11. Crew Chief - Installation Practices - Agency Staff Compared to Contractors

\begin{tabular}{|c|c|c|}
\hline \multicolumn{3}{|c|}{ Installation Practices } \\
\hline & Agency Staff & Contractor Staff \\
\hline Number of Respondents & 211 & 57 \\
\hline Install Measures Not Specified in $10 \%$ or More & $46 \%$ & $55 \%$ \\
\hline Did Not Install Specified Measure in $10 \%$ or More & $12 \%$ & $21 \%$ \\
\hline \% Auditor Consultation - "Seldom" or "Never" & $67 \%$ & $52 \%$ \\
\hline
\end{tabular}

With respect to installation quality, both types of staff were more likely to give their crews ratings of "Very Good" or "Excellent" for the more "standard" weatherization measures (i.e., infiltration/air sealing, insulation, and address issues with lead). Contractor crew chiefs rated their crews higher on HVAC work and on General Crew Safety than did agency crew chiefs (see Table 8.12).

Table 8.12. Crew Chief - Installation Quality - Agency Staff Compared to Contractors

\begin{tabular}{|c|c|c|}
\hline \multicolumn{3}{|c|}{ Installation Quality } \\
\hline & Agency Staff & Contractor Staff \\
\hline Number of Respondents & 211 & 57 \\
\hline \% "Excellent" or "Very Good" Infiltration/Air Sealing & $92 \%$ & $95 \%$ \\
\hline \% "Excellent" or "Very Good" Insulation & $92 \%$ & $94 \%$ \\
\hline \% “Excellent" or "Very Good" HVAC & $63 \%$ & $75 \%$ \\
\hline \% "Excellent” or "Very Good” Lead & $80 \%$ & $91 \%$ \\
\hline \% "Excellent" or "Very Good" Mold and Mildew & $59 \%$ & $57 \%$ \\
\hline \% "Excellent” or "Very Good" General Crew Safety & $80 \%$ & $91 \%$ \\
\hline
\end{tabular}

\subsection{CLIENTS}

Crew chiefs have significant interactions with clients. Table 8.13 shows that contractor crew chiefs are more likely to report that they have a language barrier or that clients were difficult, and were less likely to report that they did a significant amount of informal education with clients. These differences are relatively small and are not statistically significant at the 90 percent confidence level. Table 8.14 shows that there are some small, but not statistically significant, differences in whether crew chiefs felt unsafe in certain homes that they served.

Table 8.13. Crew Chief - Client Interactions - Agency Staff Compared to Contractors

\begin{tabular}{|c|c|c|}
\hline \multicolumn{3}{|c|}{ Client Interactions } \\
\hline & Agency Staff & Contractor Staff \\
\hline Number of Respondents & 211 & 57 \\
\hline$\%$ Language Barrier with $5 \%$ or More & $13 \%$ & $21 \%$ \\
\hline$\%$ Difficult Clients in $10 \%$ or More & $16 \%$ & $24 \%$ \\
\hline \% “A Great Deal” or "Some” Informal Education (Client) & $79 \%$ & $70 \%$ \\
\hline \% “A Great Deal” or "Some” Informal Education (Family) & $59 \%$ & $57 \%$ \\
\hline
\end{tabular}


Table 8.14. Crew Chief - Staff Feel Unsafe - Agency Staff Compared to Contractors

\begin{tabular}{|l|c||c||}
\hline \multicolumn{2}{|c||}{ Staff Safety } \\
\hline & Agency Staff & Contractor Staff \\
\hline Number of Respondents & 211 & 57 \\
\hline \hline \% Felt Unsafe in 10\% or More of Homes & $15 \%$ & $18 \%$ \\
\hline$\%$ Reporting "Pets" & $19 \%$ & $19 \%$ \\
\hline$\%$ Reporting House Conditions (Unsanitary) & $36 \%$ & $28 \%$ \\
\hline \% Reporting House Conditions (IAQ) & $13 \%$ & $12 \%$ \\
\hline \% Reporting House Conditions (Structural) & $12 \%$ & $12 \%$ \\
\hline \% Reporting House Conditions (Infestation) & $12 \%$ & $7 \%$ \\
\hline$\%$ Reporting Client Issues & $18 \%$ & $23 \%$ \\
\hline$\%$ Reporting Neighborhood Issues & $9 \%$ & $11 \%$ \\
\hline
\end{tabular}





\section{AGENCY VS. CONTRACTOR CREW MEMBER FINDINGS}

Some weatherization agencies use in-house crews to deliver energy services, some use contractors, and some use both types of weatherization staff. About 20 percent of crew members responding to the Baseline Survey were employed by contractors. This section of the reports presents some of the areas in which it appears that agency staff and contractor staff differ.

In general, the statistics in this section show that there are some differences between agency and contractor staff. In particular, it appears that agency staff are more likely to be salaried employees who work a normal 40-hour week and receive employee benefits (e.g., health insurance and paid time off), while contractor staff are more likely to be hourly staff who work less consistently and are less likely to receive employee benefits, but who often work more hours and have a higher annual income. However, from the perspective of training, work quality, and client interactions, there appear to be far more similarities than there are differences.

\subsection{DEMOGRAPHIC CHARACTERISTICS}

Table 9.1 summarizes the difference between the crew members who are employed by the local weatherization agency and those employed by contractors in terms of their demographic characteristics. The most important differences in the two types of staff are that agency staff are more likely to be a member of a minority group and contractor staff are more likely to speak Spanish at a conversational level. The only statistically significant difference in the projected population statistics is with respect to the percent minority. (Note: A difference of about 10 percentage points would be considered to be statistically significant at the 90 percent confidence level).

Table 9.1. Crew Chief Demographics - Agency Staff Compared to Contractors

\begin{tabular}{|l|c||c|}
\hline \multicolumn{2}{|c||}{ Demographic Characteristics } \\
\hline \hline \multicolumn{2}{|c||}{ Agency Staff } & Contractor Staff \\
\hline Number of Respondents & 214 & 50 \\
\hline \hline Median Age & 35 years & 38 Years \\
\hline$\%$ Female & $3 \%$ & $2 \%$ \\
\hline$\%$ Minority & $28 \%$ & $16 \%$ \\
\hline$\%$ Spanish Language - Conversational & $10 \%$ & $18 \%$ \\
\hline$\%$ Other Language - Conversational & $7 \%$ & $2 \%$ \\
\hline$\%$ At Least Some College & $45 \%$ & $48 \%$ \\
\hline
\end{tabular}

\subsection{EMPLOYMENT CHARACTERISTICS}

The survey questions related to crew member employment characteristics show both similarities and differences between agency and contractor staff. Table 9.2 shows that both types of staff consider weatherization to be their main job and that most work for just one employer. The statistics in Table 9.3 further support that characterization for agency staff; over one-half report that they consider weatherization to be their career. But, only 42 percent of contractor staff report that they consider weatherization to be their career. Contractor staff are a little more experienced than are agency staff. 
Table 9.2. Crew Member Employment Status - Agency Staff Compared to Contractors

\begin{tabular}{|c|c|c|}
\hline \multicolumn{3}{|c|}{ Employment Status } \\
\hline & Agency Staff & Contractor Staff \\
\hline Number of Respondents & 214 & 50 \\
\hline \% Two or More Employers & $28 \%$ & $22 \%$ \\
\hline$\%$ Weatherization is Main Job & $96 \%$ & $100 \%$ \\
\hline$\%$ Full Time or More & $97 \%$ & $92 \%$ \\
\hline$\%$ More That 40 Hours per Week & $13 \%$ & $20 \%$ \\
\hline
\end{tabular}

Table 9.3. Crew Member Weatherization Career - Agency Staff Compared to Contractors

\begin{tabular}{|c|c|c|}
\hline \multicolumn{3}{|c|}{ Employment Status } \\
\hline & Agency Staff & Contractor Staff \\
\hline Number of Respondents & 214 & 50 \\
\hline \% Weatherization is Career & $56 \%$ & $42 \%$ \\
\hline Median Years in Weatherization & 2 years & 4 years \\
\hline Median Years with Current Employer & 2 years & 5 years \\
\hline
\end{tabular}

One clear difference between agency staff and contractor staff is in the balance between job security and benefits (more for agency staff) and pay (higher for contactor staff). Table 9.4 shows that the median income is about 12 percent higher for contractor staff; however, while the majority of agency staff get health benefits, only one-fourth of contactor staff get those benefits. The job satisfaction question shows high ratings for both types of staff for interactions with clients and their co-workers. However, agency staff report higher levels of satisfaction with having steady work, paid time off, and health and retirements benefits, while contractor staff report higher levels of satisfaction with pay.

Table 9.4. Crew Member Income and Benefits - Agency Staff Compared to Contractors

\begin{tabular}{|c|c|c|}
\hline \multicolumn{3}{|c|}{ Income and Benefits } \\
\hline & Agency Staff & Contractor Staff \\
\hline Number of Respondents & 214 & 50 \\
\hline Median Income & $\$ 26,800$ & $\$ 30,000$ \\
\hline$\%$ with Health Benefits from Employer & $65 \%$ & $24 \%$ \\
\hline \multicolumn{3}{|l|}{$\%$ Satisfied with... } \\
\hline Interactions with Clients & $89 \%$ & $90 \%$ \\
\hline Co-Workers & $84 \%$ & $86 \%$ \\
\hline Steady Work & $93 \%$ & $82 \%$ \\
\hline Job Safety & $79 \%$ & $82 \%$ \\
\hline Paid Time Off Policy & $88 \%$ & $56 \%$ \\
\hline Pay & $52 \%$ & $68 \%$ \\
\hline Health Benefits & $54 \%$ & $24 \%$ \\
\hline Retirement Benefits & $52 \%$ & $24 \%$ \\
\hline
\end{tabular}




\subsection{TRAINING AND WORKFORCE DEVELOPMENT}

With respect to workforce development questions, there is a high rate of correlation between the responses for both types of staff. Almost one-half of crew members fear that they would be unemployed if not for their current work. But, both types of staff feel that the training and experience they receive would help them to get other jobs, particularly with companies that do weatherization work for market-rate programs (see Table 9.5).

Table 9.5. Crew Member - Workforce Development - Agency Staff Compared to Contractors

\begin{tabular}{|l|c|c||}
\hline \multicolumn{2}{|c||}{ Workforce Development } \\
\hline \hline & Agency Staff & Contractor Staff \\
\hline Number of Respondents & 214 & 50 \\
\hline \hline \% Likely to be Unemployed & $45 \%$ & $48 \%$ \\
\hline$\%$ Training Valuable in Other Jobs & $86 \%$ & $78 \%$ \\
\hline Where Training Most Valuable & Non-Low-Income WX & Non-Low-Income WX \\
\hline$\%$ Experience Valuable in Other Jobs & $92 \%$ & $90 \%$ \\
\hline Where Experience Most Valuable & Non-Low-Income WX & Non-Low-Income WX \\
\hline
\end{tabular}

Staff training is an important component of the delivery of high-quality weatherization services. The statistics in this section of the report assess whether agency staff and contactor staff are receiving the same amount and type of training on important weatherization topics.

Table 9.6 shows that agency staff are more likely to report that they develop "A Lot" or "Most/All" of their skills through formal training (e.g., classroom training), while contractor staff are likely to report that they developed skills through on-the-job training. Moreover, Table 9.7 shows that most agency and contactor staff report that they received on-the-job training in the last five years; many report that they received on-the-job mentoring and almost all have received some form of formal training.

Table 9.6. Crew Member - Skills Learned - Agency Staff Compared to Contractors

\begin{tabular}{|c|c|c|}
\hline \multicolumn{3}{|c|}{ Source of Weatherization Skills } \\
\hline & Agency Staff & Contractor Staff \\
\hline Number of Respondents & 214 & 50 \\
\hline $\begin{array}{l}\text { \% "A Lot" or "Most/All” Prior to Entering WX } \\
\text { Field }\end{array}$ & $38 \%$ & $26 \%$ \\
\hline \% “A Lot” or "Most/All” On-the-Job Training & $66 \%$ & $72 \%$ \\
\hline \% "A Lot" or "Most/All” Formal Training & $55 \%$ & $42 \%$ \\
\hline
\end{tabular}


Table 9.7. Crew Member - Training Approach - Agency Staff Compared to Contractors

\begin{tabular}{|c|c|c|}
\hline \multicolumn{3}{|c|}{ Type of Training Received } \\
\hline & Agency Staff & Contractor Staff \\
\hline Number of Respondents & 214 & 50 \\
\hline $\begin{array}{l}\% \text { "A Great Deal" or "Quite a Bit" On-the Job Training } \\
\text { Field }\end{array}$ & $62 \%$ & $68 \%$ \\
\hline \% "A Great Deal” or "Quite a Bit" On-the-Job Mentoring & $33 \%$ & $34 \%$ \\
\hline$\%$ At Least One Training Session in Last Five Years & $91 \%$ & $90 \%$ \\
\hline$\%$ At Training Center & $69 \%$ & $76 \%$ \\
\hline$\%$ At National Training Conference & $24 \%$ & $20 \%$ \\
\hline$\%$ At State Weatherization Conference & $22 \%$ & $14 \%$ \\
\hline
\end{tabular}

Table 9.8 shows the topics on which crew members have been trained and Table 9.9 shows the topics on which they perceive that they need additional training. With respect to the training received, the reported rate of training is with 10 percentage points for all of the listed topics. Since a difference must be at least 10 percentage points to be statistically significant at the 90 percent confidence level, the statistics do not allow one to say that one group got more or less training on specific topics than the other. Similarly, Table 9.9 shows that in terms of training needs, both agency staff and contactor staff have similar incidence rates for training needed. There is no statistical evidence from the survey that the staff are being trained differently on these important topics. With respect to the barriers to training, Table 9.10 does show that contractors are more likely to perceive that training is not at the right time or place, or to report that they lack of awareness of training. (Note: These differences are not statistically significant).

Table 9.8. Crew Member - Formal Training Topics - Agency Staff Compared to Contractors

\begin{tabular}{|c|c|c|}
\hline \multicolumn{3}{|c|}{ Training Received } \\
\hline & Agency Staff & Contractor Staff \\
\hline Number of Respondents & 214 & 50 \\
\hline \% Diagnostics Testing & $49 \%$ & $48 \%$ \\
\hline \% Infiltration/Air Sealing (Single Family) & $70 \%$ & $76 \%$ \\
\hline$\%$ Insulation (Single Family) & $66 \%$ & $74 \%$ \\
\hline$\%$ Lead & $85 \%$ & $86 \%$ \\
\hline$\%$ Mold and Mildew & $51 \%$ & $52 \%$ \\
\hline$\%$ Indoor Air Quality & $41 \%$ & $46 \%$ \\
\hline$\%$ General Crew Safety & $73 \%$ & $66 \%$ \\
\hline
\end{tabular}


Table 9.9. Crew Member - Training Needs - Agency Staff Compared to Contractors

\begin{tabular}{|c|c|c|}
\hline \multicolumn{3}{|c|}{ Training Needed } \\
\hline & Agency Staff & Contractor Staff \\
\hline Number of Respondents & 214 & 50 \\
\hline \% That Have Outstanding Training Needs & $62 \%$ & $62 \%$ \\
\hline$\%$ Need Diagnostic Testing and Assessment & $30 \%$ & $24 \%$ \\
\hline$\%$ Need Infiltration/Air Sealing (Single Family) & $13 \%$ & $12 \%$ \\
\hline$\%$ Need Insulation (Single Family) & $12 \%$ & $10 \%$ \\
\hline$\%$ Need Lead & $20 \%$ & $14 \%$ \\
\hline$\%$ Need Mold and Mildew & $26 \%$ & $24 \%$ \\
\hline \% Need Indoor Air Quality & $22 \%$ & $20 \%$ \\
\hline$\%$ Need General Crew Safety & $14 \%$ & $12 \%$ \\
\hline
\end{tabular}

Table 9.10. Crew Member - Reasons for Unmet Training Needs - Agency Staff Compared to Contractors

\begin{tabular}{|c|c|c|}
\hline \multicolumn{3}{|c|}{ Training Barrier } \\
\hline & Agency Staff & Contractor Staff \\
\hline Number of Respondents & 214 & 50 \\
\hline \% Not Available Right Time or Right Place & $22 \%$ & $28 \%$ \\
\hline$\%$ Lack of Training Funds & $8 \%$ & $6 \%$ \\
\hline$\%$ Not Aware of Training & $14 \%$ & $20 \%$ \\
\hline$\%$ Have to Pay for Own Training & $1 \%$ & $6 \%$ \\
\hline
\end{tabular}

\subsection{SERVICES}

The survey asked weatherization staff about service delivery. With respect to installation quality, Table 9.11 shows that both types of crew members were more likely to give themselves ratings of "Very Good" or "Excellent" for the more "standard" weatherization measures (i.e., infiltration air sealing, insulation, and address issues with lead).

Table 9.11. Crew Chief - Installation Quality - Agency Staff Compared to Contractors

\begin{tabular}{|c|c|c|}
\hline \multicolumn{3}{|c|}{ Installation Quality } \\
\hline & Agency Staff & Contractor Staff \\
\hline Number of Respondents & 214 & 50 \\
\hline \% "Excellent" or "Very Good" Infiltration/Air Sealing & $91 \%$ & $92 \%$ \\
\hline \% "Excellent" or "Very Good" Insulation & $86 \%$ & $94 \%$ \\
\hline \% "Excellent" or "Very Good" HVAC & $68 \%$ & $70 \%$ \\
\hline \% “Excellent" or "Very Good" Lead & $75 \%$ & $75 \%$ \\
\hline \% “Excellent” or "Very Good" Mold and Mildew & $60 \%$ & $56 \%$ \\
\hline \% "Excellent” or "Very Good" General Crew Safety & $80 \%$ & $78 \%$ \\
\hline
\end{tabular}

\subsection{CLIENTS}

Crew members have significant interactions with clients. Table 9.12 shows that both agency and contractor crew members report that they conduct a significant amount of informal education with both 
clients and members of their extended family. Table 9.13 shows that there are some small, but not statistically significant, differences in whether crew chiefs felt unsafe in certain homes that they served.

Table 9.12. Crew Member - Client Interactions - Agency Staff Compared to Contractors

\begin{tabular}{|c|c|c|}
\hline \multicolumn{3}{|c|}{ Client Interactions } \\
\hline & Agency Staff & Contractor Staff \\
\hline Number of Respondents & 214 & 50 \\
\hline \% “A Great Deal” or "Some” Informal Education (Client) & $76 \%$ & $74 \%$ \\
\hline \% "A Great Deal" or "Some" Informal Education (Family) & $59 \%$ & $48 \%$ \\
\hline
\end{tabular}

Table 9.13. Crew Member - Staff Feel Unsafe - Agency Staff Compared to Contractors

\begin{tabular}{|c|c|c|}
\hline \multicolumn{3}{|c|}{ Staff Safety } \\
\hline & Agency Staff & Contractor Staff \\
\hline Number of Respondents & 214 & 50 \\
\hline$\%$ Felt Unsafe in $10 \%$ or More of Homes & $34 \%$ & $38 \%$ \\
\hline \% Reporting "Pets" & $22 \%$ & $18 \%$ \\
\hline \% Reporting House Conditions (Unsanitary) & $43 \%$ & $42 \%$ \\
\hline$\%$ Reporting House Conditions (IAQ) & $14 \%$ & $20 \%$ \\
\hline$\%$ Reporting House Conditions (Structural) & $19 \%$ & $8 \%$ \\
\hline$\%$ Reporting House Conditions (Infestation) & $9 \%$ & $12 \%$ \\
\hline \% Reporting Client Issues & $11 \%$ & $12 \%$ \\
\hline$\%$ Reporting Neighborhood Issues & $6 \%$ & $14 \%$ \\
\hline
\end{tabular}




\section{APPENDIX A. WEATHERIZATION STAFF FOLLOW-UP SURVEY}

RESULTS 



\section{APPENDIX A. WEATHERIZATION STAFF FOLLOW-UP SURVEY RESULTS ${ }^{6}$}

In 2013, the evaluation administered a follow-up survey to all weatherization staff that completed the survey in 2011. The purpose of this survey was primarily to track, two-years later, the employment status of the respondents. There is specific interest in tracking weatherization staff that may have left the field of low-income weatherization. This is because there was some expectation that individuals trained in lowincome weatherization through WAP and DOE weatherization training centers would then go on to careers in non-low-income home retrofit.

In 2011, 882 weatherization staff completed the survey. Of these respondents, $70 \%$ of the auditors, $58 \%$ of the crew chiefs, and $41 \%$ of the crew members completed the follow-up survey. The employment status of the respondents in 2013 is presented in Table A.1. In total, 67\% of respondents were still employed by the same agency, $4 \%$ had moved to a different low-income weatherization organization, and $29 \%$ had left the field of low-income weatherization. About a quarter of respondents who were with the same agency had a different job during this time period. Crew members were more likely to have left the field than auditors and crew chiefs.

Table A.1 Employment Status of Weatherization Staff Respondents in 2013

\begin{tabular}{|c|c|c|c|c|}
\hline & $\begin{array}{c}\text { Total } \\
(\mathrm{n}=508)\end{array}$ & $\begin{array}{l}\text { Auditors } \\
(\mathrm{n}=245)\end{array}$ & $\begin{array}{c}\text { Crew Chiefs } \\
(\mathrm{n}=156)\end{array}$ & $\begin{array}{c}\text { Crew Members } \\
(\mathrm{n}=107)\end{array}$ \\
\hline Same Agency & $67 \%$ & $69 \%$ & $72 \%$ & $57 \%$ \\
\hline Same Agency, Same Job & $76 \%$ & $74 \%$ & $80 \%$ & $73 \%$ \\
\hline Same Agency, Different Job & $24 \%$ & $26 \%$ & $20 \%$ & $27 \%$ \\
\hline $\begin{array}{l}\text { Different Low-income Weatherization } \\
\text { Organization }\end{array}$ & $4 \%$ & $6 \%$ & $1 \%$ & $3 \%$ \\
\hline Left Low-Income Weatherization & $29 \%$ & $25 \%$ & $27 \%$ & $40 \%$ \\
\hline
\end{tabular}

One can ask whether employment tenure and age of respondent are related to employment status. From Table A.2, it is apparent that those who left their agencies and the field of low-income weatherization had less time at their agencies and in the field. The weatherization network was in the process of down-sizing from its ARRA period peak in 2013 and it is not surprising that those with less tenure might be more likely to have left their jobs. Crew members in particular had few years invested in their agencies and careers in low-income weatherization.

Of the 146 that left the field of low-income weatherization, only 7 reported working in the home retrofit field. Thus, there is little support from this survey that the surge in employment and training in the national low-income weatherization network has benefited the non-low-income home retrofit market. About one-fifth of the respondents moved into the construction industry and four reported working in the clean energy sector. The balance of the remaining $(n=107)$ respondents reported taking a mixture of other jobs, including these verbatim reports: security guard, sales, retail, janitor, book making, custom furniture builder, food service, health care, landfill, papermill, real estate, recycling, and lending. Fifty-five percent of the respondents reported being employed or self-employed, $32 \%$ out of work, $7 \%$ retired and $2 \%$ unable to work. Those having health insurance decreased from about $90 \%$ in 2011 to $72 \%$ in 2013 . The average reported income for those employed was unchanged from 2011 but the range of incomes increased: some benefited greatly from the move out of low-income weatherization and some saw a significant decrease in their income.

\footnotetext{
${ }^{6}$ This appendix was prepared by Bruce Tonn.
} 
Table A.2 Employment Tenure and Age of Respondents in 2011

\begin{tabular}{|l|c|c|c|c|c|}
\hline \multirow{4}{*}{$\begin{array}{l}\text { Years at } \\
\text { Agency }\end{array}$} & $\begin{array}{c}\text { Same Agency, } \\
\text { Same Job }\end{array}$ & $\begin{array}{c}\text { Same Agency, } \\
\text { Different Job }\end{array}$ & Different Wx Org. & $\begin{array}{c}\text { Left Low-Income } \\
\text { Wx }\end{array}$ \\
\cline { 2 - 6 } & Total & 8.5 & 8.5 & 6.7 & 4.7 \\
\cline { 2 - 6 } & Auditors & 9.3 & 8.6 & $*$ & 5.9 \\
\cline { 2 - 6 } & Crew Chief & 9.2 & 6.7 & $*$ & 5.3 \\
\hline Years in Low- & Crewber & 4.9 & 7.5 & 8.3 & 5.2 \\
\cline { 2 - 6 } Weatherization & Auditors & 8.7 & 8.4 & $*$ & 6.8 \\
\cline { 2 - 6 } & Crew Chief & 9.8 & 10.0 & $*$ & 5.6 \\
\cline { 2 - 6 } & Crew Member & 4.8 & 7.7 & 45 & 46 \\
\hline \multirow{3}{*}{ Age } & Total & 46 & 43 & $*$ & 51 \\
\cline { 2 - 6 } & Auditors & 46 & 43 & $*$ & 44 \\
\cline { 2 - 6 } & Crew Chief & 47 & 38 & $*$ & 42 \\
\cline { 2 - 6 } & Crew Member & 43 & & $*$ & $*$ \\
\hline
\end{tabular}

*sample size too small for estimation

Lastly, the impacts of the ARRA period on job characteristics of those still in low-income weatherization were explored. The results presented in Table A.3 suggest that salaries stayed about the same from 2011 to 2013, same with the average number of hours worked per week. Health care benefits did not change. Not surprisingly, job satisfaction during the hectic ARRA period dropped from on average being satisfactory to being neither satisfactory nor unsatisfactory. However, that more respondents reported that they would not be unemployed without their current job in 2013 than in 2011 is interesting. Since the survey did not ask why, it is only speculation how a strengthening economy, skills gained on the job, and/or having survived the initial ramp-down of the weatherization work contributed to these beliefs. 
A.3 Job Characteristics For Respondents Still in Low-Income Weatherization

\begin{tabular}{|c|c|c|c|c|c|c|c|}
\hline & \multirow[t]{2}{*}{ Job Title } & \multicolumn{2}{|c|}{$\begin{array}{c}\text { Same Agency, Same } \\
\text { Job }\end{array}$} & \multicolumn{2}{|c|}{$\begin{array}{l}\text { Same Agency, } \\
\text { Different Job }\end{array}$} & \multicolumn{2}{|c|}{$\begin{array}{l}\text { Different Low- } \\
\text { Income Wx } \\
\text { Org. }\end{array}$} \\
\hline & & 2011 & 2013 & 2011 & 2013 & 2011 & 2013 \\
\hline \multirow{4}{*}{$\begin{array}{l}\text { Annual Salary }(1=\$ 0-\$ 10,000 ; \\
3=\$ 15,001-\$ 20,000 ; 5=\$ 25,000- \\
\$ 30,000 ; 7=\$ 40,001-\$ 50,000 ; \$ 9= \\
\left.\$ 75,001^{+}\right)\end{array}$} & Total & 5.7 & 5.5 & 5.7 & 5.5 & 5.7 & $*$ \\
\hline & Auditors & 6.0 & 5.9 & 6.2 & 6.2 & $*$ & $*$ \\
\hline & Crew Chief & 5.8 & 5.3 & 5.6 & 4.7 & $*$ & $*$ \\
\hline & Crew Member & 4.9 & 4.6 & 4.5 & 5.0 & $*$ & $*$ \\
\hline \multirow[t]{4}{*}{ Hours Worked per Week } & Total & 41 & 41 & 43 & 43 & 46 & $*$ \\
\hline & Auditors & 42 & 42 & 44 & 44 & $*$ & $*$ \\
\hline & Crew Chief & 40 & 40 & 41 & 41 & $*$ & $*$ \\
\hline & Crew Member & 42 & 41 & 41 & 44 & $*$ & $*$ \\
\hline \multirow[t]{4}{*}{ Health Care } & Total & $89 \%$ & & & & $95 \%$ & $76 \%$ \\
\hline & Auditors & $94 \%$ & & & & $*$ & $*$ \\
\hline & Crew Chief & $83 \%$ & & & & $*$ & $*$ \\
\hline & Crew Member & $86 \%$ & & & & $*$ & $*$ \\
\hline \multirow{4}{*}{$\begin{array}{l}\text { Average Job Satisfaction ( } 1=\text { very } \\
\text { unsatisfactory, } 3=\text { neither, } 5=\text { very } \\
\text { satisfactory) }\end{array}$} & Total & 4.0 & 2.9 & 4.0 & 3.0 & 3.8 & $*$ \\
\hline & Auditors & 4.0 & 2.9 & 4.1 & 3.1 & $*$ & $*$ \\
\hline & Crew Chief & 4.0 & 2.8 & 4.0 & 2.7 & $*$ & $*$ \\
\hline & Crew Member & 4.0 & 2.8 & 4.0 & 3.0 & $*$ & $*$ \\
\hline \multirow{4}{*}{$\begin{array}{l}\text { Likelihood of Being Unemployed } \\
\text { w/o This Job (Likely, Very likely) }\end{array}$} & Total & $51 \%$ & $36 \%$ & $51 \%$ & $38 \%$ & $47 \%$ & $*$ \\
\hline & Auditors & $49 \%$ & $45 \%$ & $52 \%$ & $40 \%$ & $*$ & $*$ \\
\hline & Crew Chief & $51 \%$ & $29 \%$ & $50 \%$ & $37 \%$ & $*$ & $*$ \\
\hline & Crew Member & $57 \%$ & $25 \%$ & $50 \%$ & $33 \%$ & $*$ & $*$ \\
\hline
\end{tabular}

*sample size too small for estimation 